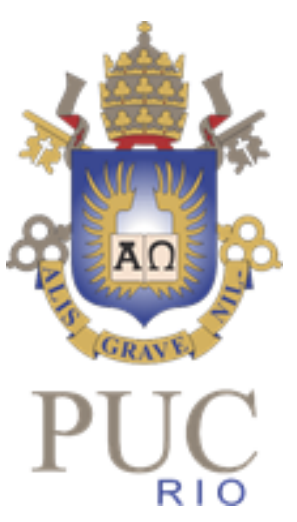

Yuri Braga da Silva Sombra

Cartografia Geomorfológica e Geodiversidade Aplicada ao
Geoturismo do Parque Nacional da Tijuca (RJ)

Dissertação de Mestrado

Dissertação apresentada como requisito parcial para obtenção do grau de Mestre em Geografia pelo programa de Pós-graduação em Geografia, do

Departamento de Geografia e Meio Ambiente da PUC-Rio.

Orientador: Prof. Dr. Marcelo Motta de Freitas

Rio de Janeiro Junho de 2021 


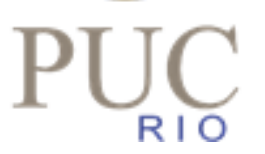

Yuri Braga da Silva Sombra

\section{Cartografia Geomorfológica e Geodiversidade Aplicada ao Geoturismo do Parque Nacional da Tijuca (RJ)}

Dissertação apresentada como requisito parcial para obtenção do grau de Mestre pelo Programa de Pós-Graduação em Geografia da PUC-Rio. Aprovada pela Comissão Examinadora abaixo:

Prof. Marcelo Motta de Freitas Orientador Departamento de Geografia e Meio Ambiente- PUC Rio

Prof. Sérgio Cadena de Vasconcellos Departamento de Geografia e Meio Ambiente- PUC Rio

Prof. Katia Leite Mansur Departamento de Geologia- UFRJ

Rio de Janeiro, 28 de junho de 2021 
Todos os direitos reservados. A reprodução, total ou parcial, do trabalho é proibida sem autorização da universidade, do autor e do orientador.

Yuri Braga da Silva Sombra

Graduou-se em Bacharelado em Geografia na Universidade Federal Fluminense em 2017, no Campus de Campos dos Goytacazes. Atuou como estagiário do Laboratório de Geologia e Análise de Sedimentos, membro voluntário no Núcleo de Estudos e Pesquisas Socioambientais (NESA) e como Bolsista do Projeto de Acessibilidade, todos vinculados a UFF.

Ficha Catalográfica

Sombra, Yuri Braga da Silva

Cartografia geomorfológica e geodiversidade aplicada ao geoturismo do Parque Nacional Da Tijuca, Rio De Janeiro (RJ) / Yuri Braga da Silva Sombra ; orientador: Marcelo Motta de Freitas. - 2021.

115 f. : il. color. ; $30 \mathrm{~cm}$

Dissertação (mestrado)-Pontifícia Universidade Católica do Rio de Janeiro, Departamento de Geografia e Meio Ambiente, 2021.

Inclui bibliografia

1. Geografia e Meio Ambiente - Teses. 2. Geomorfologia. 3. Geodiversidade. 4. Geoturismo. I. Freitas, Marcelo Motta de. II. Pontifícia Universidade Católica do Rio de Janeiro. Departamento de Geografia e Meio Ambiente. III. Título. 


\section{Agradecimentos}

O presente trabalho foi realizado com apoio da Coordenação de Aperfeiçoamento de Pessoal de Nível Superior - Brasil (CAPES) - Código de Financiamento 001.

Um trabalho de pesquisa só é possível ser realizado com ajuda de muitas pessoas. Agradeço meu orientador, Prof. Dr ${ }^{\circ}$ Marcelo Motta de Freitas pela sugestão de tema, incentivos, preciosos ensinamentos e ajuda nos trabalhos de campo.

A equipe do Grupo Morfotektos, em especial, a Fernando Gomes, Letícia Rocha e Professor Dr $^{\circ}$ Rodrigo Paixão, que auxiliaram nos campos e em várias discussões sobre a pesquisa e assuntos relacionados.

Aos colegas da turma de mestrado de 2019/1, pelas excelentes discussões em sala de aula e nos corredores da Universidade, que sempre somaram na construção da pesquisa.

A Professora Dr ${ }^{\mathrm{a}}$ Kátia Mansur e Prof. Dr ${ }^{\circ}$ Sérgio Cadena por terem participado do exame de qualificação e contribuído com discussões e dicas para a pesquisa.

Ao meu Pai Antônio Carlos, a Mãe Iracema Braga, a minha Irmã Isis Sombra e a minha Sobrinha, Jade Sombra, pelas inúmeras ajudas durante o mestrado e incentivos para a finalização do trabalho. A minha Avó Margarida, pela estadia, que foi fundamental para a realização do mestrado. A grande amiga, que já faz parte da família, Ana Maris de Figueiredo Ribeiro, pelos preciosos incentivos e por oferecer oportunidades de trabalho, que possibilitaram realizar as diversas atividades do mestrado no Rio de Janeiro. 


\section{Resumo}

Sombra, Yuri Braga da Silva; Freitas, Marcelo Motta. Cartografia Geomorfológica e Geodiversidade aplicada ao Geoturismo do Parque Nacional da Tijuca (RJ). Rio de Janeiro, 2021. 115p. Dissertação de Mestrado Departamento de Geografia e Meio Ambiente, Pontifícia Universidade Católica do Rio de Janeiro.

A presente dissertação trata da aplicabilidade da cartografia geomorfológica e da geodiversidade ao geoturismo do Parque Nacional da Tijuca, localizado no Município do Rio de Janeiro (RJ). O trabalho possui como objetivo a construção do mapeamento geomorfológico e caracterização da geodiversidade do Parque, fornecendo propostas de aplicação ao geoturismo. A área de estudo está inserida no Maciço da Tijuca no alto curso da bacia de drenagem do rio Tijuca (Setor AFloresta da Tijuca). Os métodos utilizados foram baseados em técnicas de geoprocessamento e trabalho de campo, divididos em mapeamento geomorfológico, índice de geodiversidade, mapeamento geológico e inventário de sítios de geodiversidade. A geologia é caracterizada pela presença de gnaisses ortoderivados e paraderivados, quartzitos e granitos. O relevo é representado por serras escarpadas, morros altos, colinas e rampas de tálus, colúvio e alúvio. O mapa geomorfológico se baseou na análise do índice de posição topográfica, na qual gerou 10 classes, fornecendo detalhes sobre as vertentes. $\mathrm{O}$ índice de geodiversidade, representado por densidade de kernel, forneceu a espacialização da variedade dos elementos abióticos, alternando entre muito baixa e muito alta. O mapa geológico apresentou o detalhamento das litologias encontradas na bacia do rio Tijuca, com destaque a grande presença de quartzitos do Grupo São Fidélis e ortognaisses do Complexo Rio Negro. Foram descritos 28 sítios de geodiversidade, que forneceram muitas informações úteis para a promoção do geoturismo dentro do Parque. A maioria dos pontos de visitação do alto curso da bacia do rio Tijuca possuem caráter geológico e geomorfológico, porém as informações sobre geodiversidade não estão disponíveis. A criação de placas, folder, mapas e diálogos com visitantes e moradores das áreas vizinhas do Parque, irão contribuir na conscientização do público e impulso da divulgação científica.

\section{Palavras-chave}

Geomorfologia; Geodiversidade; Geoturismo 


\begin{abstract}
Sombra, Yuri Braga da Silva; Freitas, Marcelo Motta (Advisor). Geomorphological Cartography and Geodiversity applied to Geotourism in the Tijuca National Park (RJ). Rio de Janeiro, 2021. 115p. Dissertação de Mestrado - Departamento de Geografia e Meio Ambiente, Pontifícia Universidade Católica do Rio de Janeiro.
\end{abstract}

The present dissertation deals with the applicability of geomorphologic cartography and geodiversity to the geotourism of Tijuca National Park, located in the Municipality of Rio de Janeiro (RJ). The work has as objective the construction of geomorphological mapping and characterization of the geodiversity of the Park, providing proposals for application to geotourism. The study area is inserted in the Tijuca Massif in the upper course of the Tijuca river drainage basin (Sector ATijuca Forest). The methods used were based on geoprocessing techniques and field work, divided into geomorphological mapping, geodiversity index, geological mapping and geodiversity site inventory. The geology is characterized by the presence of orthoderivative and paraderivative gneisses, quartzite and granite. The relief is represented by rugged mountains, high hills, hills and thallus ramps, colluvium and alluvium. The geomorphological map was based on the analysis of the topographic position index, which generated 10 classes, providing details about the slopes. The geodiversity index, represented by kernel density, provided the spatialization of the variety of abiotic elements, alternating between very low and very high. The geological map presented the details of the lithologies found in the Tijuca River basin, highlighting the large presence of quartzite of the São Fidélis Group and orthogneiss of the Rio Negro Complex. A total of 28 geodiversity sites were described, providing much useful information for the promotion of geotourism within the Park. Most of the visitation sites in the upper Tijuca River basin have a geological and geomorphological character, but information on geodiversity is not available. The creation of signs, folders, maps and dialogues with visitors and residents of the neighboring areas of the Park will contribute to the public awareness and impulse of the scientific dissemination.

\title{
Keywords
}

Geomorphology; Geodiversity; Geotourism 


\section{Sumário}

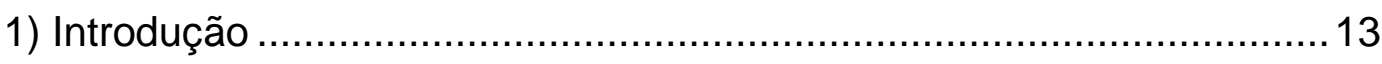

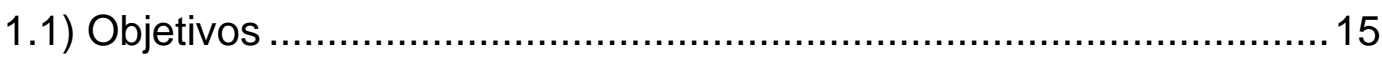

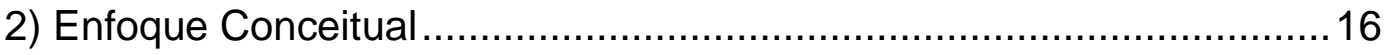

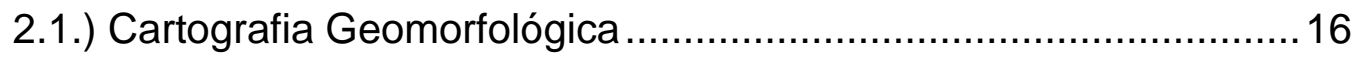

2.2) Geodiversidade, Geoturismo e Conceitos Associados ..................19

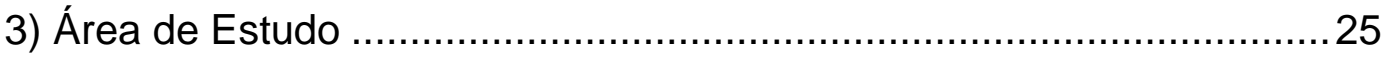

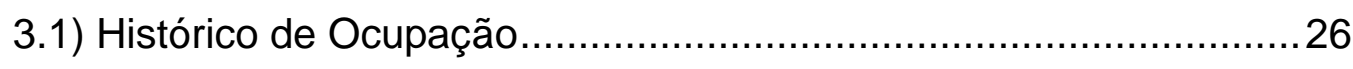

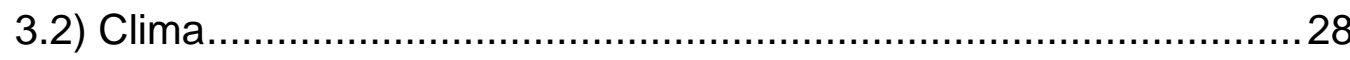

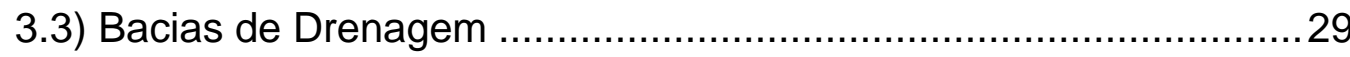

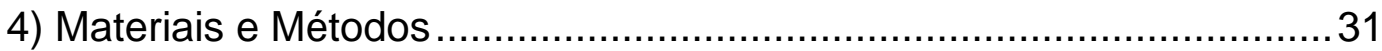

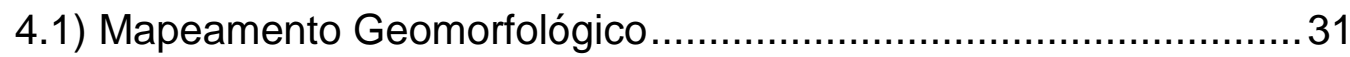

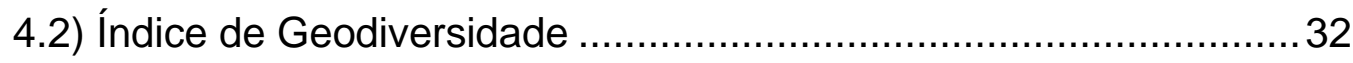

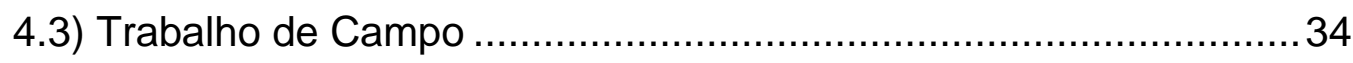

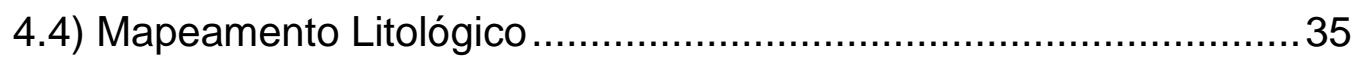

4.5) Inventário de Sítios de Geodiversidade ........................................ 38

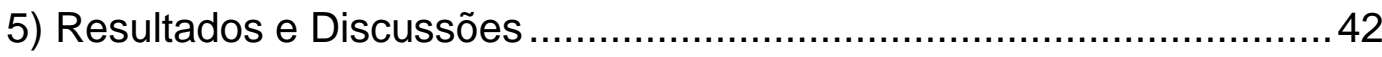

5.1) Cartografia Geomorfológica e Geodiversidade do Maciço da Tijuca

5.1.1) Contexto Geológico e Geomorfológico ...................................42

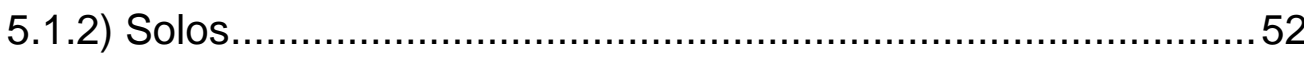

5.1.3) Cartografia do Relevo do Maciço da Tijuca ............................54

5.1.4) Índice de Geodiversidade ..................................................60

5.2) Análise da Geodiversidade Para Aplicação ao Geoturismo do Alto

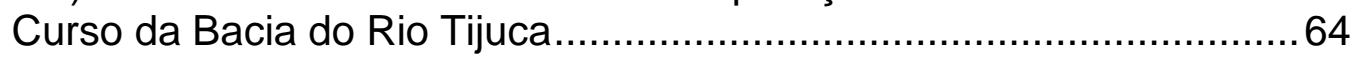

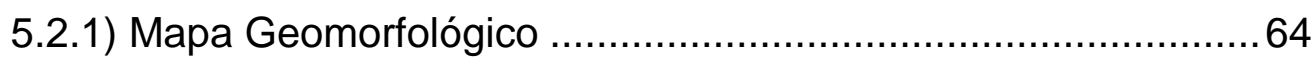

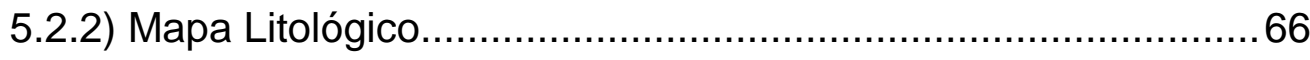

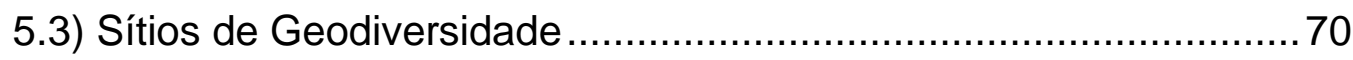

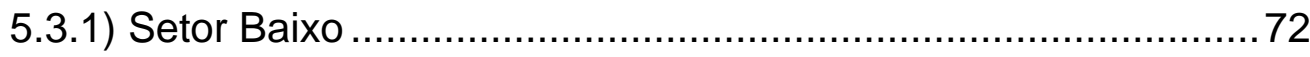

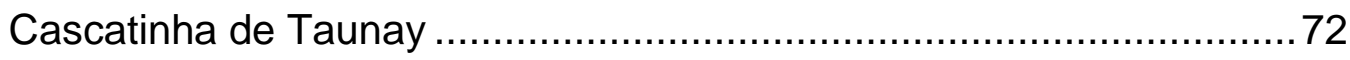

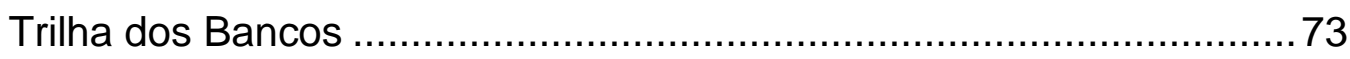

Captação de água em Biotita Gnaisse.............................................. 74

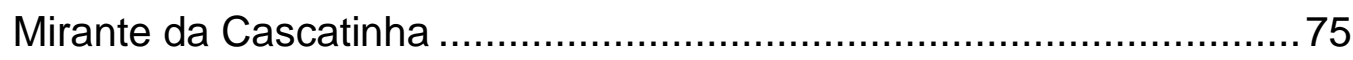

Dobra de Quartzito da Estrada da Cascatinha.....................................

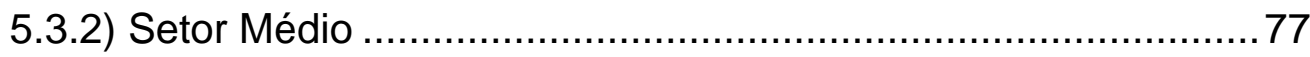

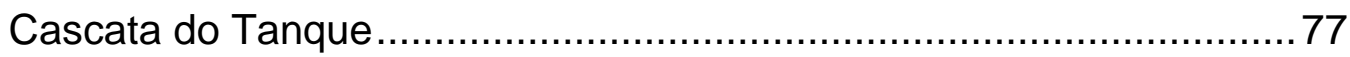

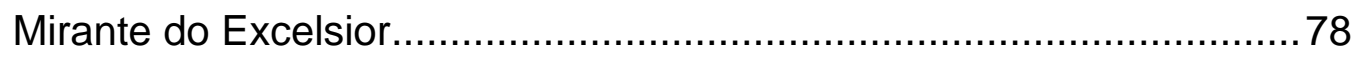




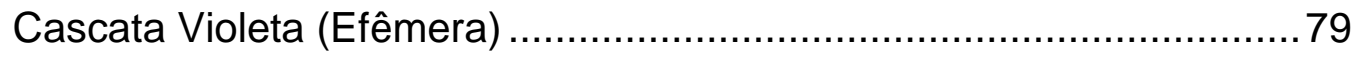

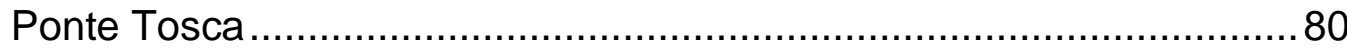

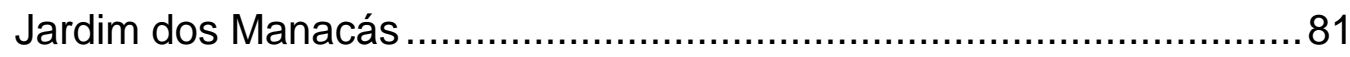

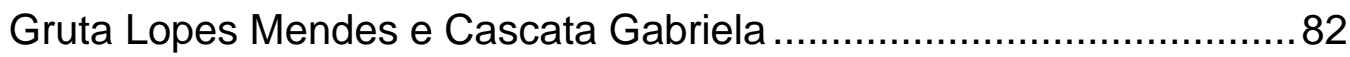

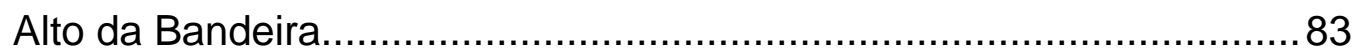

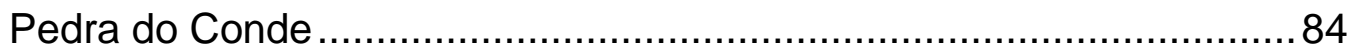

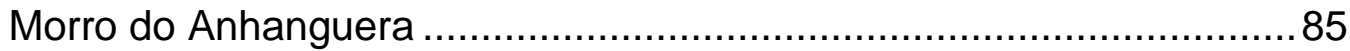

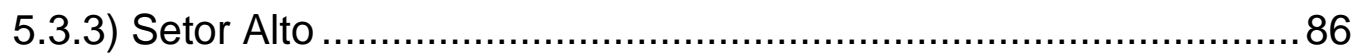

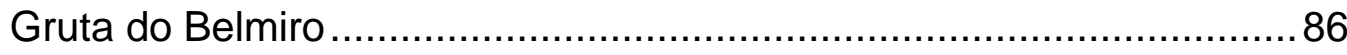

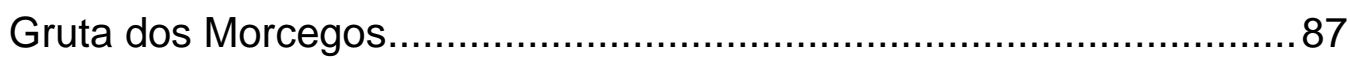

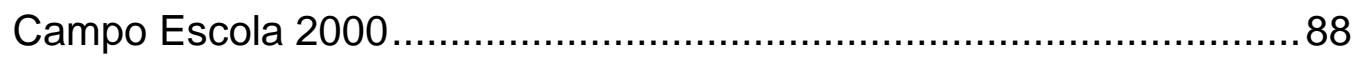

Cachoeiras do Alto Curso do Rio Archer e Gruta Paulo e Virgínia .......89

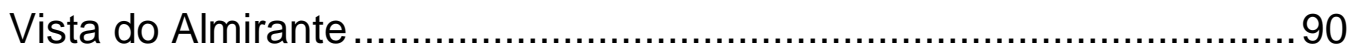

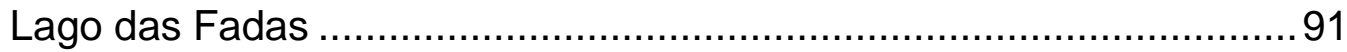

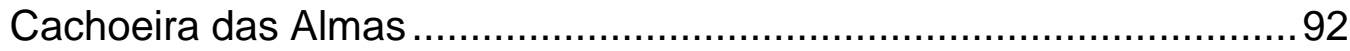

Caminho de Pedra da Serrilha da Caveira.......................................... 93

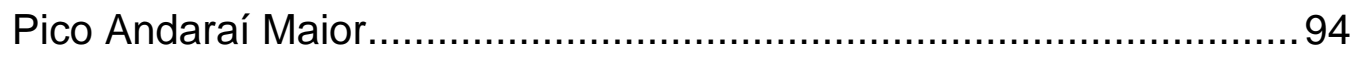

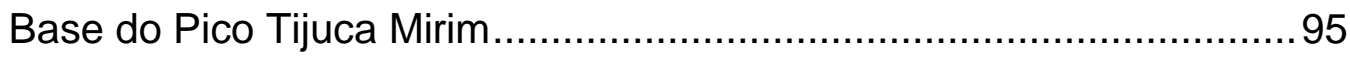

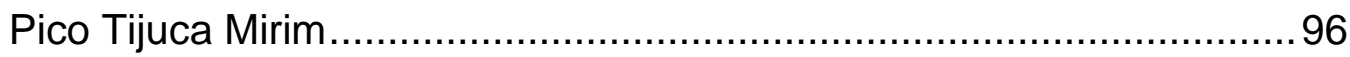

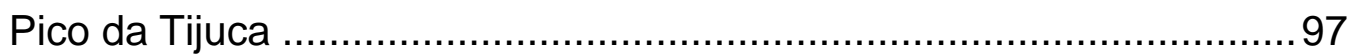

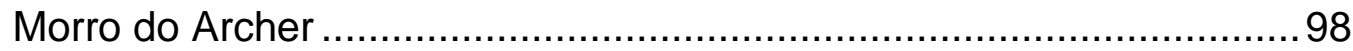

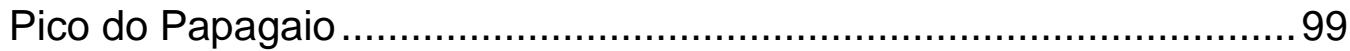

5.4) Propostas de Ações Para a Promoção do Geoturismo no Parque

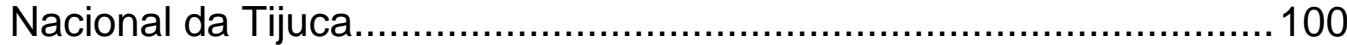

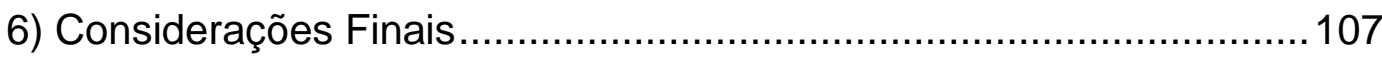

7) Referências Bibliográficas..........................................................109 


\section{Lista de Tabelas}

Tabela 1- Classes de declividade em porcentagem e graus. $\quad 30$

(LEPSCH, 1981)

Tabela 2- Levantamentos geológicos prévios que abrangem o

Maciço da Tijuca e/ou Rio de Janeiro. Adaptado de Valeriano et al. (2012)

Tabela 3- Parâmetros utilizados na quantificação de geossítios e sítios de geodiversidade com potencial educacional e turístico.

Adaptado de Brilha (2016)

Tabela 4- Valor Científico

Tabela 5- Risco de Degradação

Tabela 6- O Risco de Degradação (RD), pode ser classificado em 39 três níveis: baixo, médio, alto

Tabela 7- Potencial Uso Educativo e Turístico 39

Tabela 8- Prioridade de Proteção 40

Tabela 9- Áreas em km² e porcentagens das classes de hipsometria 53

Tabela 10- Áreas em $\mathrm{km}^{2}$ e porcentagens das classes de 55 declividade

Tabela 11- Áreas em $\mathrm{km}^{2}$ e porcentagens das classes de relevo

Tabela 12- Áreas em $\mathrm{m}^{2}$ e porcentagens das classes de relevo da 65 Bacia do Rio Tijuca

Tabela 13- Área em hectares e porcentagem das classes de geologia 


\section{Lista de Quadros}

Quadro 1- Síntese esquemática das metodologias utilizadas nos mapeamentos geomorfológicos oficiais do território brasileiro.

Extraído de Botelho \& Pelech (2019)

Quadro 2- Quadro 2- Valores da Geodiversidade segundo Murray

20

Gray (OLIVEIRA et al. 2013)

Quadro 3- Valor e serviços da geodiversidade baseada na

21

concepção de serviços ecossistêmicos. Adaptado de Silva e Nascimento (2019)

Quadro 4- Roteiro de Trabalho de Campo 


\section{Lista de Figuras}

Figura 1- Localização da área de estudo 25

Figura 2- Pintura "Cena na Floresta da Tijuca" de Henri Nicolas 26 Vinet (1875)

Figura 3- Bairros do entorno do maciço da tijuca 27

Figura 4- Bacias Hidrográficas da área de estudo e adjacências 29

Figura 5- Exemplificação da função índice de posição topográfica 31 (SILVEIRA, 2019)

Figura 6- Procedimento ilustrativo para quantificação de

32

geodiversidade, usando operações espaciais de sobreposição,

atribuição de pontos para todos os novos polígonos e

representação por kernel (FORTE, 2014)

Figura 7- Subdivisão do Sistema Orogênico Mantiqueira

42

Figura 8- Compartimentação tectônica da Região SE brasileira 43 (dados de Heilbron et al., 2004)

Figura 9- Perfil morfo-estrutural interpretado do Gráben da

Guanabara, assimétrico com borda falhada (Serra do Mar) e

borda flexural (Maciço da Tijuca)

Figura 10-Mapa geológico do Maciço da Tijuca (limite destacado 46

em preto) e adjacências

Figura 11- Mapa geomorfológico do Maciço da Tijuca (limite

destacado em preto) e adjacências

Figura 12- Vista do Pico da Tijuca com Baía da Guanabara e

Serra do Mar ao Fundo

Figura 13- Mapa de solos do Maciço da Tijuca (limite destacado

em preto) e adjacências

Figura 14- Mapa Hipsométrico do Maciço da Tijuca

44

Figura 15- Mapa de declividades do Maciço da Tijuca

Figura 16- Mapa geomorfológico do Maciço da Tijuca baseado no índice de posição topográfica

Figura 17- Mapa de índice de geodiversidade do Maciço da

Tijuca, a partir dos seguintes elementos: geologia, geomorfologia e pedologia

Figura 18- Mapa de índice de geodiversidade do Maciço da

Tijuca, a partir de quatro aspectos: geologia, geomorfologia, pedologia e hidrografia

Figura 19- Mapa geomorfológico do alto curso da Bacia de

Drenagem do Rio Tijuca

Figura 20- Mapa geológico do alto curso da Bacia de Drenagem do Rio Tijuca

Figura 21- Quartzito e Gnaisse Archer

50

52

54

56

58

60

62

Figura 22- Planície de inundação e Gnaisse Facoidal 68

Figura 23- Biotita Gnaisse, Granito Favela e Kinzigito 69

Figura 24- Mapa de sítios de geodiversidade $\quad 70$

Figura 25- Cascatinha de Taunay 72

Figura 26- Trilha dos Bancos 73

Figura 27- Captação de água em biotita gnaisse, que chega a ter 74 uma canalização do fluxo para utilização dos usuários 
Figura 28- Mirante da Cascatinha 75

Figura 29- Dobra da Estrada da Cascatinha 76

Figura 30- Sítio de geodiversidade Cascata do Tanque 77

Figura 31- Mirante do Excelsior $\quad 78$

Figura 32-Cascata Violeta $\quad 79$

Figura 33- Ponte tosca no Caminho Pedro Augusto 80

Figura 34- Jardim dos Manacás $\quad 81$

Figura 35- Gruta Lopes Mendes e Cascata Gabriela 82

Figura 36- Vista da Pedra da Gávea, Agulhinha da Gávea e Vale 83 do Alto da Boa Vista, a partir do Alto da Bandeira

Figura 37- Vistas a partir da Pedra do Conde 84

Figura 38- Alto da Bandeira $\quad 85$

Figura 39- Gruta do Belmiro $\quad 86$

Figura 40-Gruta dos Morcegos $\quad 87$

Figura 41- Sítio de Geodiversidade Campo Escola 88

Figura 42- Cachoeira do alto curso do rio do Archer e Gruta Paulo 89

e Virgínia

Figura 43- Vista do Almirante 90

Figura 44- Sítio de Geodiversidade Lago das Fadas $\quad 91$

Figura 45- Cachoeira das Almas $\quad 92$

Figura 46- Caminho de Pedra da Serrilha da Caveira 93

Figura 47- Pontos de observação a partir do Pico do Andaraí 94

Maior

Figura 48- Base do Pico Tijuca Mirim 95

Figura 49- Sítio Pico Tijuca Mirim 96

Figura 50- Pico da Tijuca $\quad 97$

Figura 51- Morro do Archer 98

Figura 52- Bico do Papagaio 99

Figura 53-: Rio Tijuca, próximo ao Centro de Visitantes do PNT 100

Figura 54-Exemplo de placa indicativa sobre a Geologia do 102 Corcovado e arredores

Figura 55- Placa na entrada do Circuito da Largatixa de Montain 104

Bike, na sub-bacia hidrográfica do rio Caveira 


\section{1) Introdução}

As discussões e planos de estratégias de conservação dos elementos naturais fazem parte da agenda de governos, organizações mundiais, organizações não governamentais entre outras entidades ocupadas em legislar, divulgar, proteger, gerir ou planejar os territórios. Por muito tempo, a temática sobre conservação ambiental ficou prioritariamente relacionada à preservação dos aspectos bióticos em detrimento dos abióticos.

A Conferência das Nações Unidas sobre o Meio Ambiente e o Desenvolvimento (Eco 92), realizada em 1992 no Rio de Janeiro (RJ), foi um marco no processo de conservação ambiental e de fato em suas considerações estavam presentes uma campanha de maior atenção aos aspectos geológicos e geomorfológicos, assim como a Conferência de Malvern sobre Conservação Geológica e Paisagística, realizada no Reino Unido em 1993 (GRAY, 2004; MACHADO e AZEVEDO, 2015). Neste contexto, as rochas, suas tipologias e estruturas, os solos, as formas do relevo e os caminhos das águas também estão vinculados a esta categoria, pois no conceito de ecossistema estão inseridos os fatores abióticos, compondo os geossistemas, onde a relação entre elementos vivos e não vivos se dão de maneira imbricada. Essa concepção, associada ainda às transformações antropogênicas, culturais e sociais é denominada geodiversidade, fazendo alusão ao termo biodiversidade e apresentando a variedade de formas de relevo, rochas, falhas, dobras, rios e fósseis. O estudo e promoção da geodiversidade contribuem não somente para a preservação do meio físico-biótico como também para o planejamento territorial, desenvolvimento econômico e divulgação científica.

O Município do Rio de Janeiro apresenta como característica marcante a alternância entre planícies, serras residuais, morros e imponentes maciços montanhosos como o da Pedra Branca, Medanha e Tijuca. Esta característica é reflexo da instalação e desenvolvimento do Rift da Guanabara e seus eventos tectônicos, reorganizando a topografia carioca (ASMUS e FERRARI, 1978; FERRARI, 2001; VALERIANO et al., 2012). Muitas destas feições são cultuadas e frequentadas por diversas pessoas afim de se realizar atividades turísticas, possuindo apelo estético, recreativo e ambiental, devido a configuração de sua paisagem. No entanto, a paisagem vai além dos fatores físicos e bióticos apenas, ela é composta também das apropriações e transformações humanas. Para Vitte (2007) 
"a paisagem é o resultado imediato da intencionalidade humana na superfície terrestre. Seja ontem ou hoje, por meio dos mais variados meios técnicos e científicos, a sociedade imprime sua marca no espaço que fica registrada na paisagem" (pág. 79), e, ao mesmo tempo, a apropriação da paisagem, a vincula à categoria de espaço representação (HAESBAERT, 2014). As diferentes apropriações dos aspectos da paisagem compõem uma perspectiva espacial geográfica sobre os elementos e formas da paisagem. Apesar de físicos, biológicos ou socioculturais, os aspectos da paisagem dependem do olhar do observador, que, inevitavelmente, está vinculado a sua condição geográfica (cultura, crenças, formação, acesso, etc.) e, portanto, define àquele elemento uma forma de percepção e apropriação.

Percebendo a necessidade de representação e valorização de patrimônios da geodiversidade, também chamados de geopatrimônios, que nem sempre são visibilizados, o presente trabalho trata da aplicabilidade da cartografia geomorfológica e da geodiversidade ao geoturismo do Parque Nacional da Tijuca (PNT), localizado no Município do Rio de Janeiro (RJ). A ênfase da pesquisa se dá na bacia de drenagem do Rio Tijuca inserida no setor Floresta do PNT, onde aparentemente muitas de suas potencialidades paisagísticas, vinculadas a geodiversidade, não são valorizadas em todos os aspectos que podem expressar. Segundo Beliani e Scheiner (2012) o PNT é um território de patrimônio integral de múltiplos valores que envolvem em seu contexto paisagens, sítios, edificações, biodiversidade, geodiversidade e interação humana em interdependência. Nesse sentido o presente trabalho também vem contribuir para a valorização e visibilização dos aspectos da geodiversidade presente nesse setor do Parque, criando subsídios para a exploração de sua potencialidade geoturística. A pesquisa está vinculada ao grupo de pesquisa Morfotektos (Departamento de Geografia e Meio Ambiente da PUC RIO/ Faculdade de Geologia da UERJ), que vem desenvolvendo pesquisas sobre a geomorfologia (mapeamento e evolução) e temas relacionados a geodiversidade do Maciço da Tijuca.

O PNT é conhecido internacionalmente por seus atributos naturais e históricos. É cercado por uma imponente floresta, locais de visita que ressaltam a exuberância da paisagem e possui um valioso patrimônio histórico. O Parque é cercado pela densa ocupação da cidade do Rio de Janeiro e por diversas comunidades em suas fronteiras. Não há grande quantidade de estudos que abordam 
a geodiversidade associada ao geoturismo, como também faltam pesquisas sobre mapeamento das formas de relevo em detalhe, haja visto os trabalhos de Francisco (1996), Fernandes e Menezes (2005), Coelho Netto et al. (2007), Roza (2007), Souza et al. (2008), Farias et al. (2011), Teixeira et al. (2012), Beliani e Scheiner (2012), Fernandes et al. (2012), Mazur (2013) e Motoki et al. (2015), Arona (2017) e Sêmedo (2017). Portanto, este trabalho visa aprofundar as discussões geomorfológicas, buscando preencher lacunas existentes e dar continuidade aos estudos anteriores, ao mesmo tempo que pretende valorizar e visibilizar possíveis patrimônios da geodiversidade inseridos no Parque.

\section{1) Objetivos}

O presente trabalho objetiva caracterizar a geodiversidade presento no setor A do Parque Nacional da Tijuca, a partir de mapeamentos geomorfológico e geológico, criando subsídios à aplicação de seus temas ao geoturismo na Unidade de Conservação. Como objetivos específicos, a pesquisa visa:

- Gerar mapas geomorfológico e geológico do alto curso da Bacia do rio Tijuca (escala 1:10.000);

- Gerar mapa de índice de geodiversidade;

- Identificar e descrever sítios de geodiversidade com potencial geoturístico;

- Elaborar propostas de potencialização da geodiversidade para o geoturismo no setor Floresta do Parque 


\section{2) Enfoque Conceitual}

\section{1.) Cartografia Geomorfológica}

De acordo com os pressupostos de Penck (1953, apud Ross e Moroz, 1995) o relevo é produto da interação entre elementos exogenéticos e endogenéticos, o que embasou fundamentalmente criação dos conceitos de morfoestrutura e morfoescultura, por Gerasimov e Mecerjakov (1968 apud ROSS e MOROZ, 1995). Tais conceitos auxiliaram nas ações para classificação do relevo e suas formas. Para Sato e Lupinacci (2019) "o mapa geomorfológico constitui a base das pesquisas ambientais. Além da representação cartográfica das feições morfológicas, o mapa, como produto final, é a concepção sintética do relevo, o fundamento da pesquisa geomorfológica" (pág.14). O mapa geomorfológico é um dos mais complexos mapas sobre aspectos do meio físico pois envolve muitos processos atuais e evolutivos. Ele deve conter informações sobre morfologia, morfogênese, morfocronologia e morfometria, ou seja, tempo e dinâmica no mesmo tema. Em função disso, até hoje, muitas discussões ainda giram em torno de uma definição padronizada de um sistema de classificação do relevo que possa unificar as diversas propostas nacionais e internacionais. De acordo com Botelho \& Pelech (2019) isso ocorre devido às inúmeras configurações morfológicas proporcionadas por distintos complexos geológicos, climáticos, pedológicos e vegetacionais, que estão em constante mudança.

Klimaszewski (1990) declara que os primeiros conceitos de mapa geomorfológico surgem com Passarge (1912; 1914; 1920 in KLIMASZEWSKI, 1990) e Gehne (1912, in KLIMASZEWSKI, 1990). Ainda segundo o autor, o mapa geomorfológico de detalhe (como conhecemos nos dias atuais) surge somente após a Segunda Guerra Mundial. O $18^{\circ}$ Congresso Internacional de Geografia realizado no Rio de Janeiro (RJ) em 1956, foi um grande marco na evolução do pensamento geomorfológico, pois fora criado uma subcomissão sobre o tema, que buscou o aprimoramento deste conhecimento, resultando na criação de um manual de mapeamento do relevo, liderado por Jaromir Demek (1972). De acordo com Florenzano (2008) este sistema vinculado a International Geographical Union (IGU) utiliza o modelo das formas, no qual enfatiza a morfologia e a morfogênese 
e destacam as características das vertentes. Florenzano (2008) também destaca outras implementações de classificação do relevo, a exemplo do International Institute for Aerial Survey and Earth Sciences, proposto por Verstappen e Zuidam (1975) e o sistema francês, proposto por Tricart (1972).

No Brasil (quadro 1) se destacam os trabalhos do projeto RADAM Brasil entre as décadas de 1970 e 1980 (a partir da década de 1980 o projeto foi incorporado ao IBGE), Ross (1985 e 1992), Ross e Moroz (1996), IBGE (2006), CPRM (2006) e Dantas (2013). Recentemente, no ano de 2019 foi realizado dentro do XVIII Simpósio Brasileiro de Geografia Física e Aplicada (Fortaleza-CE) o $1^{\circ}$ Workshop de Cartografia Geomorfológica, no qual se estabeleceu de fato as bases para a criação do Sistema Brasileiro de Classificação do Relevo, e posteriormente, ainda no de 2019, fora realizado o $1^{\circ}$ Workshop sobre o Sistema Brasileiro de Classificação de Relevo. 
Quadro 1- Síntese esquemática das metodologias utilizadas nos mapeamentos geomorfológicos oficiais do território brasileiro. Extraído de Botelho \& Pelech (2019).

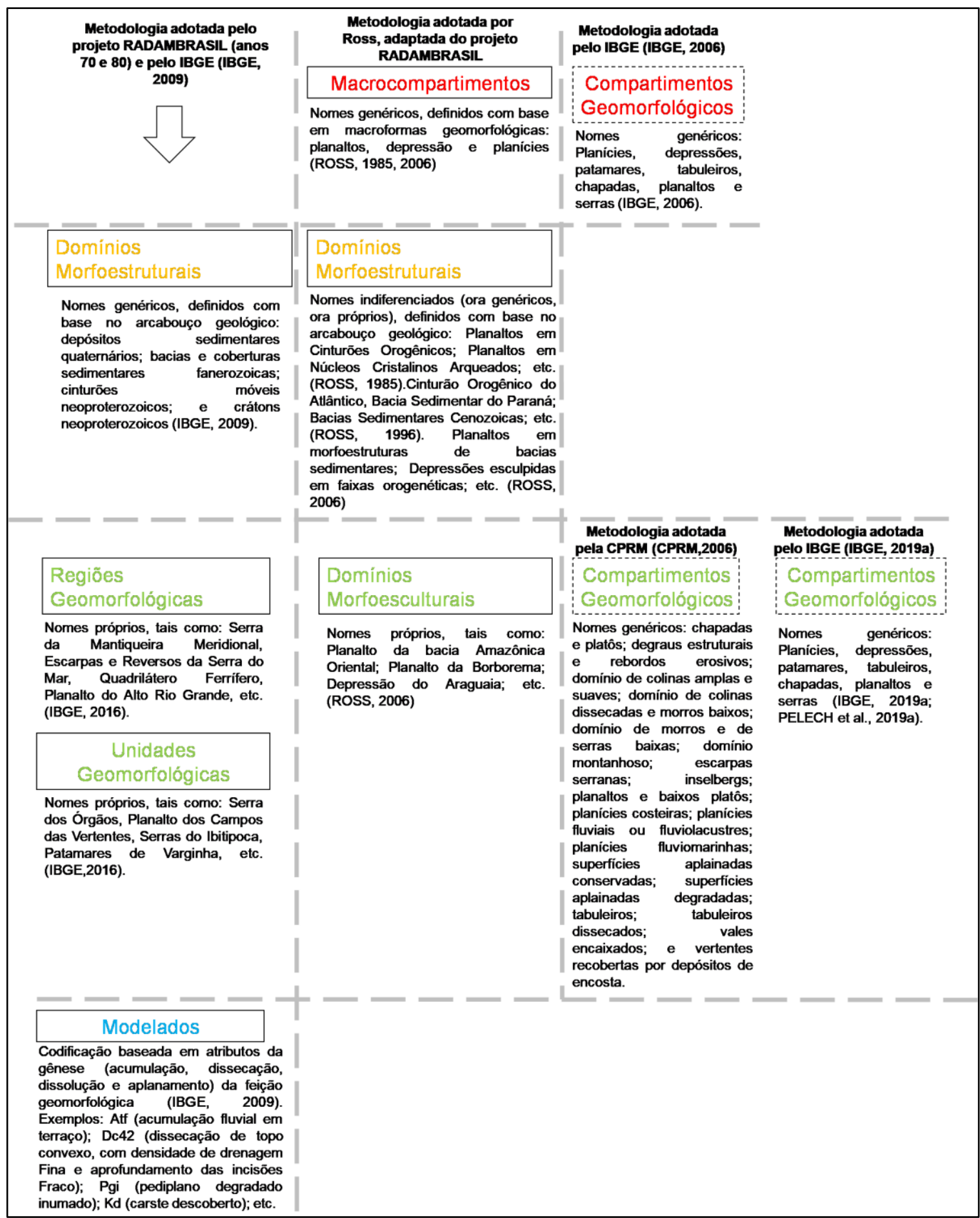

A utilização de níveis hierárquicos é marcante dentro da cartografia geomorfológica, como apontado em Ross (1992), demostrando a importância da utilização da taxonomia na representação das formas de relevo. Em seu trabalho o autor estabelece seis níveis de táxons. O primeiro se refere as morfoestruturas: grandes feições determinadas pelas estruturas geológicas, tectônica ativa e arranjo 
litológico. O segundo são as morfoesculturas, que são feições produzidas pelas ações climáticas pretéritas e/ou atuais sobre uma estrutura. Os padrões de formas semelhantes, influenciados diretamente pelos climas atuais representam o terceiro nível da taxonomia citada, tendo como exemplo em Ross (1992) os padrões em colinas, formas tabulares ou em morros. Mesmo em padrões de feições semelhantes, são encontradas variações em suas fisionomias, como na classificação de Dantas (2013), que diferencia as superfícies aplainadas em conservadas e degradadas. Estas mudanças nas formas são vinculadas ao quarto táxon. O quinto, por sua vez, possui relação direta com as geometrias das vertentes, classificando-as em côncavas, convexas, retilíneas, abruptas entre outras, possuindo gênese recente. Por último, o sexto táxon se refere a feições pequenas, recentes ou atuais, vinculadas aos processos dinâmicos que alteram a morfologia e também podem possuir influência antrópica, como as voçorocas, sulcos, cicatrizes de movimentos de massa, depósitos aluviais e bancos de assoreamento.

Atualmente a cartografia geomorfológica está sendo beneficiada pela utilização de técnicas geomorfométricas, que auxiliam no refinamento das pesquisas e em classificações semi-automáticas, com modernos modelos digitais de terreno e de elevação e imagens orbitais e aéreas. Porém, mesmo com todos esses avanços, as operações manuais em SIG, observação em cartas topográficas físicas e trabalhos de campo são de extrema importância, pois dão embasamento e validam as investigações.

\section{2) Geodiversidade, Geoturismo e Conceitos Associados}

A geodiversidade é um conceito originado formalmente na década de 1990. Segundo Gray (2004) geólogos e geomorfólogos começaram a utilizar o termo geodiversidade na década de 1990 para descrever a variedade dos elementos abióticos da natureza. Surge como contraponto à biodiversidade, haja visto que as ações relacionadas a conservação ambiental consideravam prioritariamente os aspectos bióticos. Jorge \& Guerra (2016) declaram que as ações de conservação dos elementos abióticos são realizadas há mais de 100 anos, porém é somente a partir das últimas décadas que pesquisas de cunho geoconservacionista vêm ganhando destaque no mundo científico. 
Brilha (2005) destaca a definição de geodiversidade da Royal Society for Nature Conservation do Reino Unido, na qual "consiste na variedade de ambientes geológicos, fenômenos e processos ativos que dão origem as paisagens, rochas, minerais, fósseis, solos e outros depósitos superficiais que são o suporte para a vida na Terra" (pág. 17). A partir de uma ótica integrada com o meio social e biótico, Stanley (2002) define geodiversidade como sendo o elo entre pessoas, paisagens e sua cultura através da interação da biodiversidade, solos, minerais, rochas, fósseis, processos ativos e o ambiente construído. Já Gray (2004) expõe que se trata da variedade de aspectos geológicos (rochas, minerais, fósseis), características geomorfológicas (formas e processos) e do solo. Inclui suas associações, relações, propriedades, interpretações e sistemas. No Brasil se destacam os trabalhos pioneiros de Veiga (1999), Xavier da Silva e Carvalho Filho (2001), DNPM (2005), CPRM (2006; 2008) e Nascimento et al (2008), que trouxeram as bases para o entendimento sobre a geodiversidade e conceitos associados. No trabalho de Gray (2004), o autor expõe seis valores para a geodiversidade (quadro 2), os quais são úteis para a elaboração de estratégias de conservação e pesquisas sobre o tema: intrínseco, cultural, estético, econômico, funcional e científico-educativo. Já em trabalho mais recente, o autor propõe o valor intrínseco e cinco serviços ecossistêmicos (Quadro 3): regulação, suporte, provisão, culturais e conhecimento (GRAY, 2013). Esta última abordagem se baseia nos serviços ecossistêmicos e possui também 25 processos e bens vinculados aos serviços mencionados. 
Quadro 2- Valores da Geodiversidade segundo Murray Gray (OLIVEIRA et al. 2013).

\begin{tabular}{|c|c|c|c|}
\hline \multirow{2}{*}{$\begin{array}{l}\text { Valor } \\
\text { Valor } \\
\text { Intrinseco }\end{array}$} & Definiçâo & \multicolumn{2}{|c|}{ Exemplos } \\
\hline & $\begin{array}{l}\text { valor próprio da natureza, } \\
\text { independente da valoração } \\
\text { atribuida pela sociedade. }\end{array}$ & 1 - Valor intrínseco & $\begin{array}{l}\text { Natureza abiótica livre de } \\
\text { valorações humanas }\end{array}$ \\
\hline \multirow{4}{*}{$\begin{array}{l}\text { Valor } \\
\text { Cultural }\end{array}$} & \multirow{4}{*}{$\begin{array}{l}\text { É atribuído pela sociedade, } \\
\text { quando existe uma relação } \\
\text { social, cultural, religiosa com o } \\
\text { meio físico que o rodeia, como } \\
\text { por exemplo, questöes ligadas } \\
\text { a arqueologia, folclore, } \\
\text { religião, geomorfologia }\end{array}$} & 2 - Folclore & "Devils Tower" \\
\hline & & $\begin{array}{l}3 \text { - } \\
\text { Histórico/Arqueológico }\end{array}$ & "Alibates Flint Quarries" \\
\hline & & 4-Espiritual & "Chief Mountain" \\
\hline & & $\begin{array}{l}5 \text { - Sensação de } \\
\text { pertencimento }\end{array}$ & John Muir em Yosemite \\
\hline \multirow[t]{6}{*}{$\begin{array}{l}\text { Valor } \\
\text { Estético }\end{array}$} & \multirow{6}{*}{$\begin{array}{l}\text { E um valor relacionado ao } \\
\text { impacto que é causado aos } \\
\text { sentidos. }\end{array}$} & 6 - Paisagens locais & $\begin{array}{l}\text { Vistas do mar, sons de } \\
\text { ondas, toque de areia }\end{array}$ \\
\hline & & 7-Geoturismo & Grand Canyon; Yellowstone \\
\hline & & 8 - Atividades de lazer & $\begin{array}{l}\text { Montanhismo, exploração } \\
\text { de caverna. }\end{array}$ \\
\hline & & $\begin{array}{l}9 \text { - Apreciação via } \\
\text { meios de comunicação }\end{array}$ & $\begin{array}{l}\text { Documentários sobre a } \\
\text { natureza }\end{array}$ \\
\hline & & $\begin{array}{l}10 \text { - Atividades } \\
\text { voluntárias }\end{array}$ & $\begin{array}{l}\text { Construção de caminhos. } \\
\text { restauraçäo de minas }\end{array}$ \\
\hline & & 11 - Inspiraçäo artística & Pinturas \\
\hline \multirow{7}{*}{$\begin{array}{l}\text { Valor } \\
\text { Económico }\end{array}$} & \multirow{7}{*}{$\begin{array}{l}\text { E um valor baseado na } \\
\text { dependência da sociedade em } \\
\text { relação aos elementos da } \\
\text { geodiversidade, sendo mais } \\
\text { compreensivel e objetivo. São } \\
\text { exemplos, a dependència do } \\
\text { homem pelos combustiveis } \\
\text { fósseis, materiais geológicos } \\
\text { para construção civil, aguas } \\
\text { subterrâneas, etc. }\end{array}$} & 12 - Energia & Carvão; Petróleo \\
\hline & & 13 - Minerais industriais & Potássio; Caulinita; etc \\
\hline & & 14 - Minerais metálicos & $\begin{array}{l}\text { Ferro; prata; zinco; ouro: } \\
\text { etc. }\end{array}$ \\
\hline & & $\begin{array}{l}15 \text { - Minerais de } \\
\text { construção }\end{array}$ & $\begin{array}{l}\text { Rocha; agregados: } \\
\text { calcários; betumes }\end{array}$ \\
\hline & & 16 - Gemas & Diamantes; Safiras; etc. \\
\hline & & 17 - Fósseis & $\begin{array}{l}\text { Tiranossauros; lojas de } \\
\text { fósseis e minerais }\end{array}$ \\
\hline & & 18 - Solo & $\begin{array}{l}\text { Produção de alimentos: } \\
\text { madeira; etc. }\end{array}$ \\
\hline \multirow[t]{8}{*}{$\begin{array}{l}\text { Valor } \\
\text { Funcional }\end{array}$} & \multirow{8}{*}{$\begin{array}{l}\text { Refere-se ao valor da } \\
\text { geodiversidade que está: a) } \\
\text { em seu local de origem e } \\
\text { possui caráter utilitário para o } \\
\text { homem e b) enquanto base } \\
\text { para a sustentaça do de } \\
\text { sistemas físicos e ecológicos } \\
\text { na superficie da Terra. }\end{array}$} & 19 - Plataformas & $\begin{array}{l}\text { Infraestruturas e construção } \\
\text { em terra }\end{array}$ \\
\hline & & $\begin{array}{l}20 \text { - Armazenamento e } \\
\text { reciclagem }\end{array}$ & $\begin{array}{l}\text { Armazenamento de } \mathrm{CO}_{2} \text { : } \\
\text { aquiferos }\end{array}$ \\
\hline & & 21 - Saúde & $\begin{array}{l}\text { Nutrientes e minerais: } \\
\text { paisagens terapêuticas. }\end{array}$ \\
\hline & & 22 - Aterros & $\begin{array}{l}\text { Aterro humano, câmeras de } \\
\text { lixo atômico }\end{array}$ \\
\hline & & $\begin{array}{l}23 \text { - Controle de } \\
\text { poluiçãa }\end{array}$ & $\begin{array}{l}\text { Solo e rocha como filtros de } \\
\text { água }\end{array}$ \\
\hline & & 24 - Química da água & $\begin{array}{l}\text { Agua mineral, whisky, } \\
\text { cerveja }\end{array}$ \\
\hline & & 25 - Funçöes do solo & $\begin{array}{l}\text { Agricultura, horticultura, } \\
\text { viticultura, florestamento }\end{array}$ \\
\hline & & $\begin{array}{l}26 \text { - Funçöes do } \\
\text { geossistema }\end{array}$ & $\begin{array}{l}\text { Processos costeiros, } \\
\text { fluviais, glaciais }\end{array}$ \\
\hline \multirow{4}{*}{$\begin{array}{l}\text { Valor } \\
\text { Cientifico e } \\
\text { educativo }\end{array}$} & \multirow{4}{*}{$\begin{array}{l}\text { Refere-se à importância dos } \\
\text { elementos da geodiversidade } \\
\text { para a investigaçäo científica e } \\
\text { para a educação. }\end{array}$} & 28 - Pesquisa cientifica & $\begin{array}{l}\text { História da terra, evoluçäo } \\
\text { geoprocessos }\end{array}$ \\
\hline & & $\begin{array}{l}29 \text { - História da } \\
\text { pesquisa }\end{array}$ & $\begin{array}{l}\text { Identificação de } \\
\text { desconformidades; etc. }\end{array}$ \\
\hline & & $\begin{array}{l}30 \text { - Monitoramento } \\
\text { ambiental }\end{array}$ & $\begin{array}{l}\text { Mudança de clima, } \\
\text { mudança do nível do mar, } \\
\text { poluiçäo }\end{array}$ \\
\hline & & $\begin{array}{l}31 \text { - Educação e } \\
\text { treinamento }\end{array}$ & $\begin{array}{l}\text { Estudos de campo, } \\
\text { treinamento especializado. }\end{array}$ \\
\hline
\end{tabular}


Quadro 3- Valor e serviços da geodiversidade baseada na concepção de serviços ecossistêmicos. Gray (2013) modificado por Silva e Nascimento (2019).

\begin{tabular}{|c|c|c|}
\hline Valor e Serviços & Definição & \\
\hline Intrínseco & $\begin{array}{l}\text { Esse valor é, o que toda a } \\
\text { geodiversidade possui, uma } \\
\text { vez que sua simples existência } \\
\text { possibilita a relação da } \\
\text { sociedade com a natureza, } \\
\text { independente de qual relação é } \\
\text { estabelecida entre esses } \\
\text { atores. }\end{array}$ & Bens e Processos \\
\hline Regulação & $\begin{array}{l}\text { Compreendem os processos } \\
\text { que têm por finalidade o } \\
\text { controle natural das condições } \\
\text { ambientais, seja do ar, da água } \\
\text { e dos solos. }\end{array}$ & \begin{tabular}{lc} 
Processos & atmosféricos \\
oceânicos, & \multicolumn{2}{c}{ processos } \\
terrestres, & controle de \\
inundação e de qualidade da \\
água.
\end{tabular} \\
\hline Suporte & $\begin{array}{l}\text { São aqueles nos quais a } \\
\text { geodiversidade dispõe de } \\
\text { recursos para } \\
\text { desenvolvimento } \\
\text { atividades do ser humano ou } \\
\text { da própria natureza, e que } \\
\text { dependam diretamente dos } \\
\text { solos e das rochas para ser } \\
\text { realizadas }\end{array}$ & $\begin{array}{l}\text { Processos do solo, } \\
\text { disponibilização de habitat, } \\
\text { plataforma, sepultamento e } \\
\text { armazenamento. }\end{array}$ \\
\hline Provisão & $\begin{array}{l}\text { É responsável por } \\
\text { disponibilizar bens materiais } \\
\text { para as sociedades humanas, } \\
\text { sendo o de mais fácil } \\
\text { compreensão porque, na } \\
\text { maioria dos casos, possui um } \\
\text { valor monetário associado ao } \\
\text { bem, que passa a ser tratado } \\
\text { como produto. }\end{array}$ & 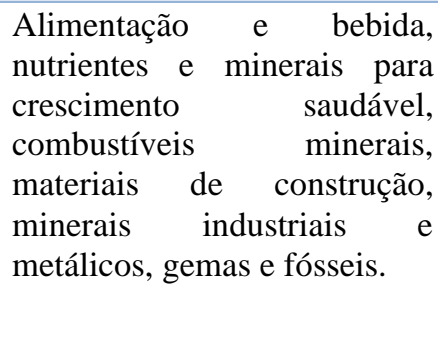 \\
\hline Culturais & $\begin{array}{l}\text { Está associado com a relação } \\
\text { da sociedade a algum aspecto } \\
\text { abiótico do ambiente por seu } \\
\text { significado social ou } \\
\text { comunitário. }\end{array}$ & $\begin{array}{l}\text { Qualidade ambiental, } \\
\text { geoturismo e atividades de } \\
\text { lazer, significado cultural, } \\
\text { espiritual e histórico, } \\
\text { inspiração artística e } \\
\text { desenvolvimento social. }\end{array}$ \\
\hline Conhecimento & $\begin{array}{l}\text { Estão relacionados com } \\
\text { propostas de utilização da } \\
\text { natureza abiótica, como sala } \\
\text { de aula e laboratório, sendo } \\
\text { sua exploração puramente } \\
\text { científica e educacional. }\end{array}$ & $\begin{array}{l}\text { História da Terra, história da } \\
\text { pesquisa, monitoramento } \\
\text { ambiental, geoforense, } \\
\text { educação e emprego. }\end{array}$ \\
\hline
\end{tabular}

A análise sobre a variedade do meio abiótico possui objetivo de ressaltar a necessidade de conservar os elementos terrestres como também divulgar de forma facilitadora a toda a sociedade. Uma das formas de expandir tais estudos para o público leigo é o geoturismo, configurando-se em uma importante forma de divulgação científica. De acordo com Nascimento et al. (2008) "atividades turísticas ligadas ao patrimônio geológico já ocorrem há muito tempo, porém, o 
termo 'geoturismo' passou a ser amplamente divulgado na Europa após ser definido pelo pesquisador inglês Thomas Hose, em 1995, em uma revista de interesse ambiental (pág. 148). É importante salientar que há definições de geoturismo com outras conotações, como por exemplo, a descrição da National Geographic Society (NGS), em conjunto com a Travel Industry Association (TIA), dos EUA, na qual visa preservar o caráter geográfico do destino, ressaltando os atributos naturais e humanos que caracterizam um lugar distinto de outro (STUEVE et al., 2002). Ainda de acordo com os autores, "o geoturismo engloba preocupações culturais e ambientais sobre viagens, bem como o impacto local que o turismo tem sobre as comunidades e suas economias individuais e estilos de vida" (pág. 1). Tal definição apresenta caráter mais generalista e engloba diversos elementos (o que não deixa de ser importante), porém o conceito mais utilizado atualmente se refere as características da geodiversidade de uma determinada área que são importantes na promoção do turismo sustentável e educativo.

De acordo com Hose (2000), é provisão de instalações e serviços interpretativos para promover o valor e o benefício social dos sítios geológicos e geomorfológicos e seus materiais e garantir sua conservação, para o uso de estudantes, turistas e para usos recreacionais. Para Newsome \& Dowling (2006) o 'geo' se refere a geologia e geomorfologia, destacando os recursos naturais da paisagem, formas de relevo, fósseis, rochas e minerais com ênfase a apreciação dos processos que criaram esses elementos naturais. A Declaração de Arouca (2012) se tornou um marco importante, pois forneceu diretrizes para a promoção do geoturismo. Estabelecida dentro do Congresso Internacional de Geoturismo, no ano de 2011, dentro do Arouca Geopark (Portugal), a definição do conceito fica estabelecida como o turismo que sustenta e incrementa a identidade de um território, considerando a sua geologia, ambiente, cultura, valores estéticos, património e o bem estar dos seus residentes. Complementando as demais definições, Chen et al. (2020) destacam que se trata de um turismo emergente e científico para o aumento da consciência do público sobre as ciências da terra

Há outros conceitos importantes que estão relacionados intimamente com a geodiversidade e geoturismo, como geoconservação, geopatrimônio e geoparque. Sharples (2002) aponta que geoconservação trata da preservação da geodiversidade (geologia, relevo e solo) considerando a manutenção da magnitude e taxas de mudança desses aspectos. Brilha (2005) destaca que, em um sentido mais amplo 
visa a utilização e gestão sustentável da diversidade abiótica e em sentido restrito busca a conservação de certos elementos da geodiversidade que evidenciem qualquer tipo de valor superlativo. O geopatrimônio ou patrimônio geológico, segundo Brilha (2016) representa a ocorrência in situ de componentes da geodiversidade com grande valor científico, denominados geossítios, e elementos de geodiversidade, que ocorrem ex situ, e mesmo não estando em seu local de origem, apresentam relevância para a educação, turismo, ciência e cultura.

Os geoparques estão sendo instalados em diversos locais do mundo, como forma de intensificar a promoção e conservação dos componentes abióticos e contribuir para o desenvolvimento territorial e regional. Segundo Mansur (2010) "é uma área com significativo patrimônio geológico e com uma estrutura de gestão coerente e forte, baseada em uma estratégia de desenvolvimento econômico sustentável” (pág. 18). 


\section{3) Área de Estudo}

O PNT compreende uma área que engloba grande parte do Maciço da Tijuca. Possui cerca de $39,51 \mathrm{~km}^{2}$ e se constitui como uma das áreas de maior destaque de cobertura florestal no Município do Rio de Janeiro, ocorrendo locais com densa floresta, mas em grande parte composta por formações secundárias da Mata Atlântica (figura 1). O Parque é dividido em quatro setores: Floresta da Tijuca, Serra da Carioca, Pedra da Gávea e Pedra Bonita e Serras dos Pretos Forros/ Covanca.

A área selecionada para a condução desse estudo situa-se dentro do setor Floresta do Parque, sendo delimitada pela Bacia do alto Rio Tijuca, compreendida a partir do limite interior do Parque em sua portaria principal na Praça Afonso Viseu. A intenção desse recorte foi concentrar os levantamentos na unidade bacia de drenagem do alto rio Tijuca. A bacia possui $4,70 \mathrm{~km}^{2}$ de área total, sendo 3,68 $\mathrm{km}^{2}$ localizados dentro dos limites do PNT (Figura 1). 


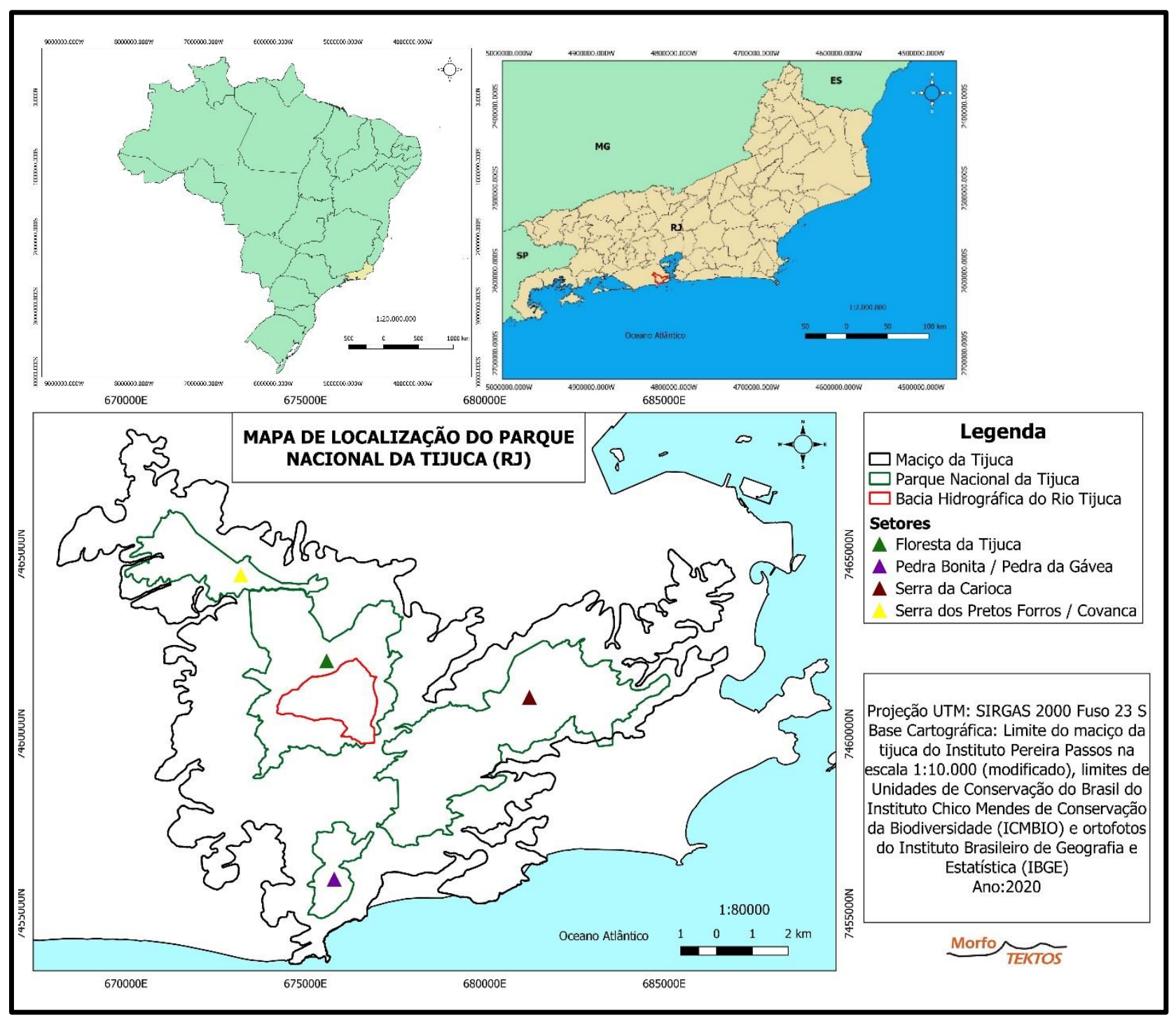

Figura 1- Localização da área de estudo

\section{1) Histórico de Ocupação}

Diversos bairros das zonas sul, oeste, norte e central do Município do Rio de Janeiro (Figuras 1 e 3) fazem fronteira com os limites do Parque. Além dessa unidade de conservação, gerida pelo ICMBio em nível federal, algumas outras unidades de conservação municipais e estaduais, protegem os patrimônios da geodiversidade do maciço, como o Parque Estadual do Grajaú e o Parque Natural Municipal Penhasco Dois Irmãos. O maciço foi marcado pela ocupação para produção cafeeira e fornecimento de madeira e carvão no século XIX. De acordo com Sales e Guedes Bruni (2019), importantes reflorestamentos ocorreram entre os anos de 1862 e 1894, como forma de reconstituir a floresta degradada pelo cultivo do café e garantir o plano de crescimento da cidade, que dependia de suas nascentes. Com isso, o tecido florestal recomposto foi protegido e apesar do imaginário 
popular considerar áreas da atual Floresta da Tijuca como pristinas e intocadas, na verdade, são espaços que sofreram intervenção humana para sua atual exuberância (figura 2).

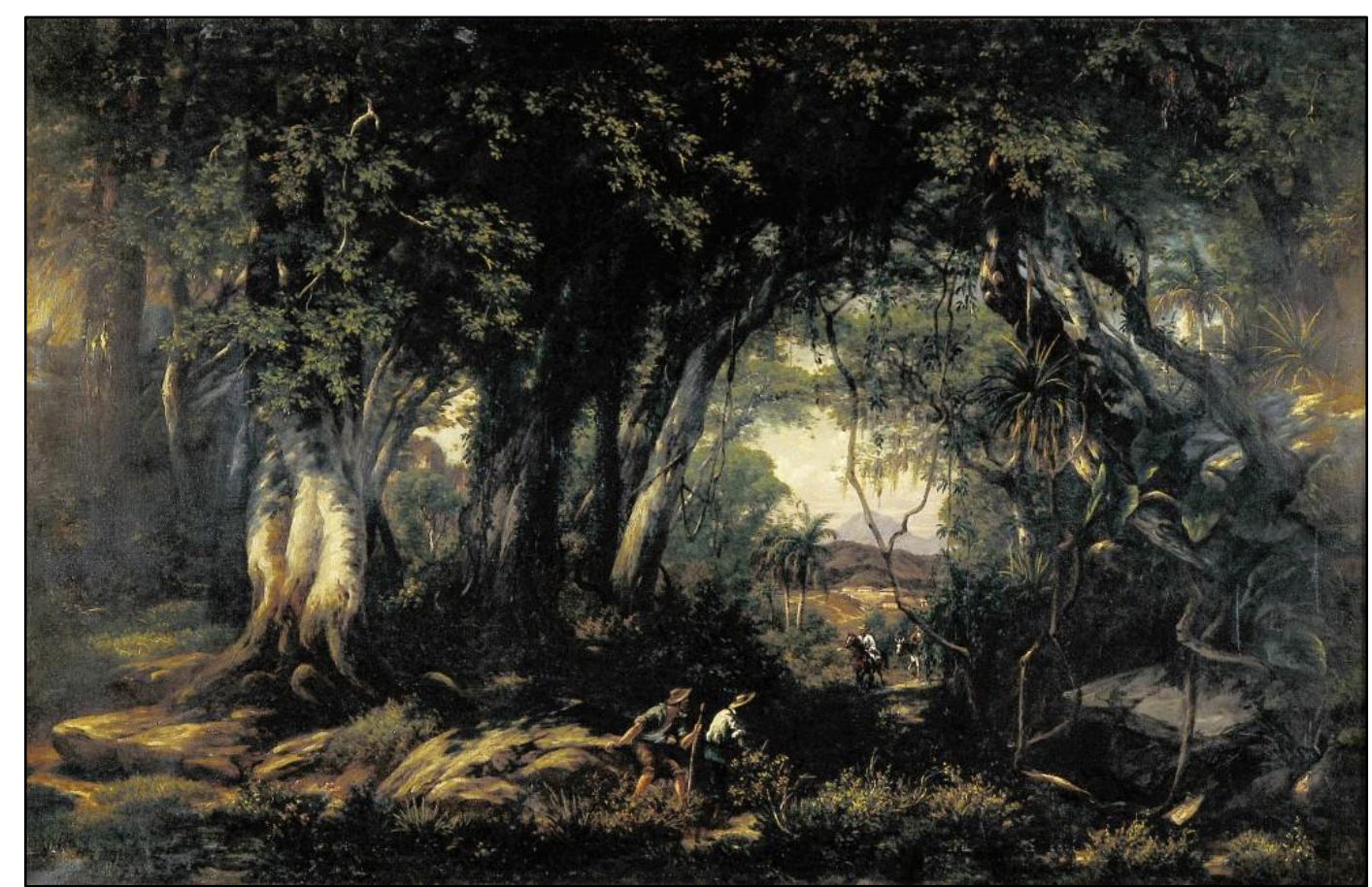

Figura 2- Pintura "Cena na Floresta da Tijuca" de Henri Nicolas Vinet (1875). Fonte: Picturing the Americas. Disponível em: https://picturingtheamericas.org/painting/at-thetijuca-forest/?lang=pt-pt.

Ao mesmo tempo, as pressões do crescimento urbano nos arredores do maciço avolumaram-se, sobretudo nas últimas décadas da expansão da cidade com sua crise de moradia. Em muitas encostas do Maciço se deu o processo de favelização, marcado pela precariedade de moradias e serviços, em função da falta de política de habitação pelas esferas de gestão pública. Em outras, a expansão de condomínios de classe abastada ou construções de casas isoladas, que ilegalmente buscavam captar os recursos hídricos do Parque, compuseram o cenário de pressão sobre seus limites. A pressão da expansão urbana sobre os limites do parque foi contundente em décadas passadas, tendo sido redesenhado em 2004, até hoje, sendo um desafio a ser considerado. De acordo com Malta e Costa (2009) este aspecto contraria a Lei de Zoneamento Municipal, que consta do Decreto no 322 de 1976, que proíbe a urbanização de áreas acima da cota de 100 metros.

Juntam-se a estas questões a própria dinâmica hidrológica e erosiva do Maciço que podem configurar vetores de degradação. Figueiró e Coelho Netto (2009) afirmam, por exemplo, que: 


\begin{abstract}
"A ocorrência de eventos de precipitação intensa, somados à grande declividade das vertentes, à ocupação desordenada destas encostas (com degradação das áreas de floresta) e à existência de um "favorecimento estrutural" (intensificação do escoamento subsuperficial na base dos paredões rochosos, fraturamentos da rocha com geração de artesianismos), tem levado a um aumento do processo erosivo e ao deslocamento recorrente de grande volume de sedimentos, na forma de movimentos de massa, especialmente nas vertentes norte e oeste do Maciço, onde a degradação da floresta ou a sua substituição pelas áreas de capim, tem se tornado um fenômeno bastante frequente na última década" (pág. 191).
\end{abstract}

O PNT é classificado como uma unidade de proteção integral, segundo a categorização do Sistema Nacional de Unidades de Conservação (SNUC- Lei 9985/2000). Os desafios acerca dos impactos ambientais não estão somente nas áreas fora da unidade. A exemplo disso, Nunes (2013) destaca o caso das linhas de transmissão e das antenas do Morro do Sumaré. Estas estruturas geram micro-ondas termais, não termais e não ionizantes que impacta os animais, a biota e as pessoas. Assim, o autor declara que as linhas de transmissão surgem como objetos marcados na paisagem e que possuem uma função específica, trazendo consequências espaciais diretas na transformação da paisagem.

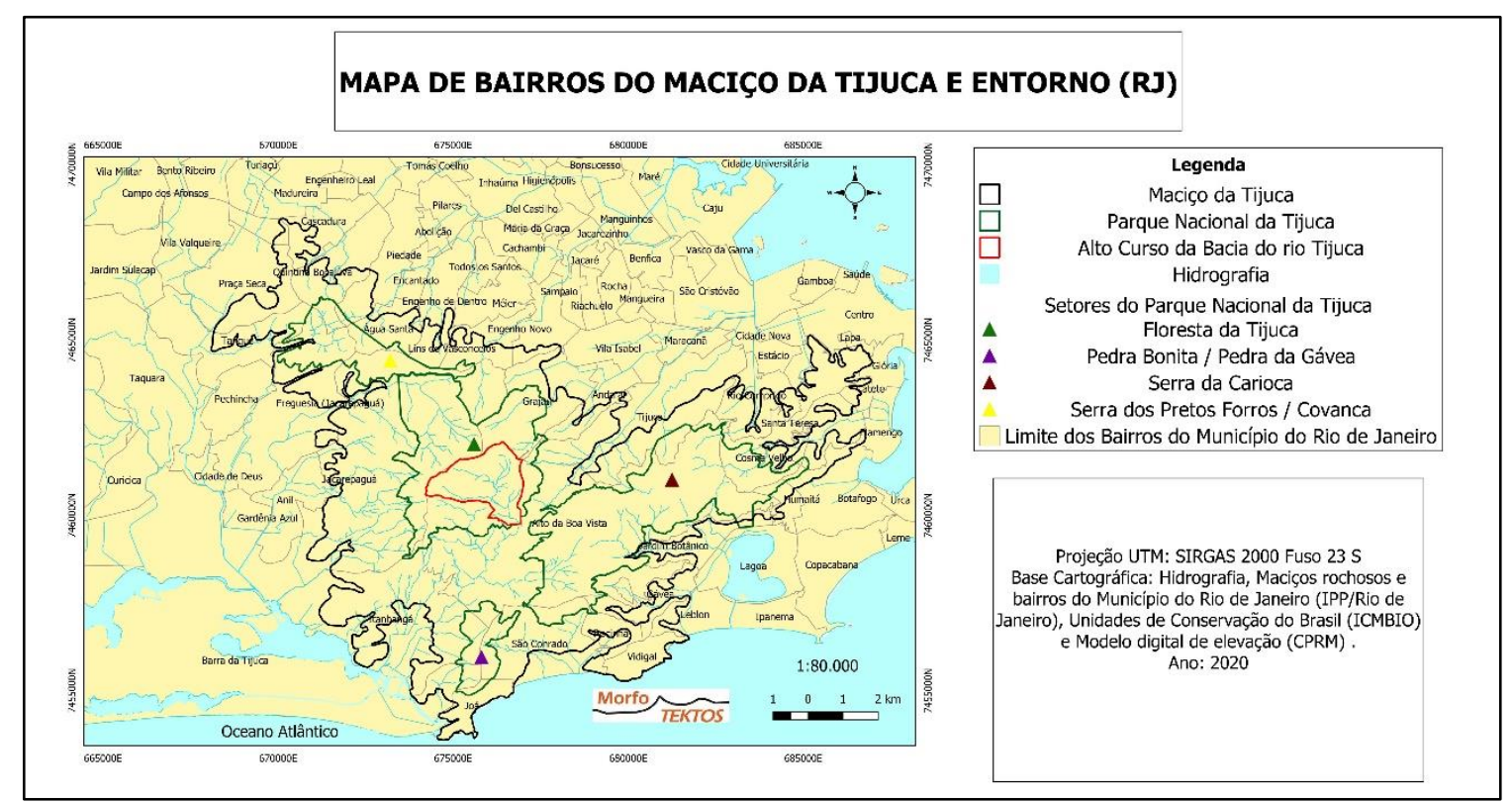

Figura 3- Bairros do entorno do maciço da tijuca.

\title{
3.2) Clima
}

O Centro Sul Brasileiro possui forte influência da Massa Atlântica Tropical sobre sua dinâmica atmosférica. Segundo Borsato e Mendonça (2012) se trata de uma massa de ar anticiclonal e possui a Alta Subtropical do Atlântico Sul como centro formador. Nos meses frios preserva as suas características por vários dias 
consecutivos e no verão, o forte aquecimento do continente a descaracteriza em poucos dias. O Rio de Janeiro também é afetado pela Zona de Convergência do Atlântico Sul (ZCAS). De acordo com Alvarenga (2012) é definida como uma persistente banda de nebulosidade, mais ativa durante a estação de verão da América do Sul.

Para a área de estudo, o clima, por sua vez, é classificado como tropical de altitude, possui temperatura média de $22^{\circ} \mathrm{C}$ e precipitação média anual entre $2000 \mathrm{e}$ 2500 mm (FIGUEIRÓ e COELHO NETTO, 2009). Possui como característica marcante um verão chuvoso e quente e inverno com menor precipitação, definindo a dinâmica climatológica anual. No interior da bacia hidrográfica do rio Tijuca há uma estação pluviométrica, denominada capela Mayrink. O Maciço da Tijuca é marcado pelas altas taxas de precipitação, influenciada pela ação orográfica do relevo, na qual em determinados anos, atuaram como catalisadores de risco e desastres.

\section{3) Bacias de Drenagem}

Os sistemas hidrográficos no Maciço da Tijuca são divididos em vertentes que drenam fluxos e materiais para a Baía de Guanabara (norte), Baixada de Jacarepaguá (oeste) e para a Lagoa Rodrigo de Freitas ou diretamente para o Oceano Atlântico em sua parte sul (figura 4). As drenagens também são impactadas pelo incorreto despejo de esgoto e usos da terra, já fora da delimitação do PNT.

A parte norte, se trata da vertente a sotavento, por isso há menor disponibilidade hídrica, maior ocorrência de áreas desmatadas e uma forte mancha urbana que descaracterizou a paisagem original, gerou efeitos negativos nas atividades hidrológicas e poluição dos rios. Neste setor se destacam as bacias hidrográficas do Canal do Mangue e do Canal do Cunha.

Nos arredores da Baixada de Jacarepaguá (barlavento) ocorrem drenagens que fluem materiais para a Lagoa da Tijuca. As vertentes possuem menor índice de eficiência de drenagem e maior tendência a ocorrência de enchentes nas baixadas conectadas a estas, com exceção da Bacia do rio Cachoeira, que possui maior suscetibilidade a movimentos de massa e eficiência de drenagem (FERNANDES $e t$ al., 2006). As maiores bacias hidrográficas deste sistema são as bacias do rio Arroio Grande, Anil e Cachoeira. 
As drenagens da vertente sul possuem menores dimensões e também situamse a barlavento em relação aos ventos que chegam do mar, que de acordo com Fernandes et al. (2006), possui maior tendência a deslizamentos e alta eficiência de drenagem, reflexo das altas declividades e densidade de eixos de concavidade. A Bacia da Lagoa Rodrigo de Freitas se torna a mais representativa dessas bacias com a maior participação no recolhimento dos fluxos hídricos da vertente sul do maciço.

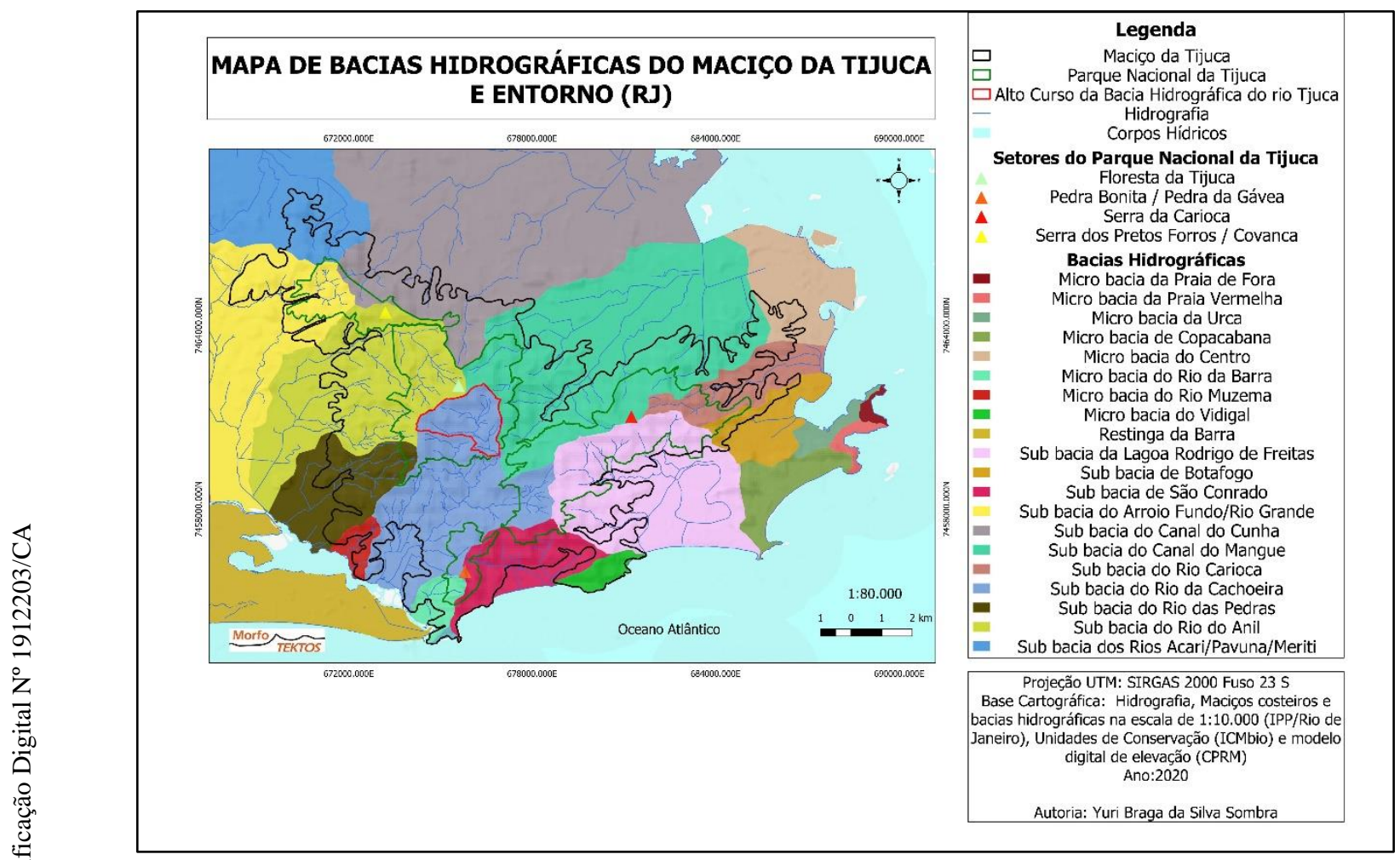

Figura 4- Bacias Hidrográficas da área de estudo e adjacências. 


\section{4) Materiais e Métodos}

\section{1) Mapeamento Geomorfológico}

A primeira etapa da pesquisa buscou obter informações sobre características morfométricas do Maciço da Tijuca, através da geração de mapas de hipsometria e declividade. Estas variáveis auxiliam de forma concisa na análise da configuração do relevo. Segundo Mello e Ferrari (2001) uma simples análise hipsométrica pode ser capaz de evidenciar indicadores do controle tectônico na compartimentação do relevo, embora não conclusiva. Silva (2012) aponta que o mapa hipsométrico permite a representação de áreas que possuem a mesma medida de altura da superfície terrestre com relação a um determinado nível horizontal ou datum, no caso, o nível médio do mar. De acordo com Valeriano (2008), a declividade é o ângulo de inclinação da superfície local em relação ao plano horizontal, podendo ser expressa em graus ou em porcentagem.

Todas as análises foram realizadas no software QGIS 3.4 Madeira, com a utilização de imagens SRTM. A hipsometria foi reclassificada, a fim de estabelecer classes bem definidas para se observar as diferenças das altitudes de forma nítida. Para isso, foi utilizado plugin do GRASS GIS no QGIS 3.4, através da ferramenta r.recode. A declividade foi obtida através da ferramenta raster, onde fora selecionada a opção de gerar declividade expressa em porcentagens (figura 10). Posteriormente, esta variável foi reclassificada, utilizando a ferramenta r.reclass do plugin GRASS GIS, baseada em Lepsch (1991).

Tabela 1- Classes de declividade em porcentagem e graus. (LEPSCH, 1981).

\begin{tabular}{|c|c|c|}
\hline \multirow[t]{2}{*}{ Classes de relevo } & \multicolumn{2}{|c|}{ Declividade } \\
\hline & $\%$ & Graus \\
\hline Plano & $0-2$ & $0^{\circ}$ a $1^{\circ} 8^{\prime} 45^{\prime \prime}$ \\
\hline Suave Ondulado & $2-5$ & $1^{\circ} 8^{\prime} 45^{\prime \prime}$ a $2^{\circ} 51^{\prime} 45^{\prime \prime}$ \\
\hline Ondulado & $5-10$ & $2^{\circ} 51^{\prime} 45^{\prime \prime}$ a 542'38”' \\
\hline Moderadamente Ondulado & $10-15$ & 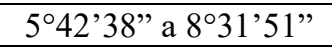 \\
\hline Forte Ondulado & $15-45$ & $8^{\circ} 31^{\prime} 51^{\prime \prime}$ a 2413'40" \\
\hline Montanhoso & $45-70$ & $24^{\circ} 13^{\prime} 40^{\prime \prime}$ a 3459'31" \\
\hline Escarpado & $>70$ & $>34^{\circ} 59^{\prime} 31^{\prime \prime}$ \\
\hline
\end{tabular}

No processo de classificação do relevo, houve a intenção de detalhar as informações para o Maciço da Tijuca, haja visto a falta de informação sobre este aspecto, assim como para a Bacia Hidrográfica do rio Tijuca dentro dos limites do PNT. O mapa de Dantas (2019) é atualmente o mais completo para o Município do Rio de Janeiro, baseado no quarto táxon proposto por Ross (1992). Como 
mencionado anteriormente, neste mapa o limite da área de estudo não apresenta uma grande variedade de formas, tendo como maior ocorrência o domínio serrano.

Portanto, há a necessidade de aprimorar as investigações, a fim de obter resultados detalhados baseados no quinto táxon. A metodologia de Weiss (2001) se mostrou eficiente para a presente pesquisa, pois se baseia em atributos morfométricos. O método consiste em obter informações da compartimentação do relevo pelo índice de posição topográfica (IPT). De acordo com Silveira e Silveira (2018) este índice é derivado de um algoritmo que mensura a diferença entre a elevação de um ponto central (Z0) e a média da elevação do seu entorno a partir de um raio predeterminado $(Z)$, descrito na equação: IPT $=$ Z0 - Z. Silveira (2019) aponta que valores positivos indicam que a célula se situa mais elevada que o entorno, valores negativos representam células mais rebaixadas e valores próximos a zero indicam células com declive constante (figura 5). É possível gerar informações sobre relevo, bacias de drenagem e declividade com esse parâmetro, como em Weiss (2001). Para esta etapa fora utilizado o plugin do SAGA GIS no QGIS 3.4, onde é possível gerar automaticamente este índice e as classes de relevo pela ferramenta Tpi based landform classification.

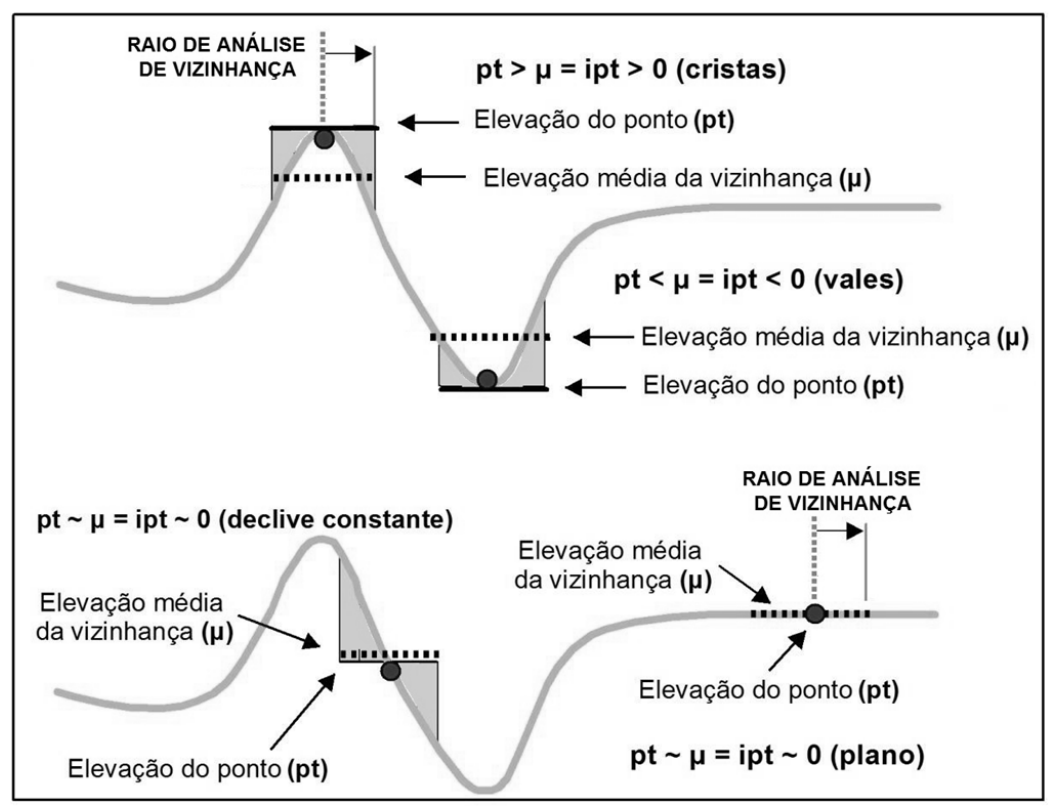

Figura 5-Exemplificação da função índice de posição topográfica (SILVEIRA, 2019).

\section{2) Índice de Geodiversidade}

As pesquisas em geodiversidade se desdobram em investigações qualitativas e quantitativas. Segundo Ruchkys et al. (2018) as primeiras estão 
relacionadas a descrição e identificação dos valores expostos por Gray (2004), enquanto os métodos quantitativos são baseados na análise integrada de seus elementos com uso de Sistemas de Informação Geográfica (SIG), com o desenvolvimento de índices numéricos utilizados para calcular a diversidade abiótica, nos quais irão indicar no mapa as áreas com maior ou menor geodiversidade.

A geração de índices de geodiversidade não possui metodologia única, onde algumas vezes se utiliza cálculo de grades vetoriais ou realiza a interpolação por Kernel entre outras técnicas, há exemplo de Kozlowski (2004), Serrano e Luiz Flaño (2007), Hjort e Luoto (2010), Pereira et al. (2013), Forte (2014), Santos et al. (2017), Betard e Peulvast (2019) e Silva et al. (2019).

O presente estudo se baseou na metodologia da análise de centróides (figura 13) e densidade de Kernel, conforme utilizada por Forte (2014) e Silva et al. (2019). Para gerar os centróides, é necessário ter as camadas vetoriais em polígonos e transforma-las em pontos, porém a camada não perde as informações da tabela de atributos. Posteriormente é feita a junção dos shapefiles e a classificação pelo índice de Kernel. Os elementos de geodiversidade utilizados na operação foram:

1. Geologia e estruturas geológicas - Folha Baía de Guanabara, escala 1:100.000 (VALERIANO et al., 2012);

2. Geomorfologia - Carta de padrões de relevo do Município do Rio de Janeiro/RJ, 1:25.000 (DANTAS, 2019);

3. Pedologia - Mapa semidetalhado de solos do Município do Rio de Janeiro/ RJ, escala 1:75.000 (LUMBRERAS e GOMES, 2004);

4. Hidrografia - Escala 1:10.000. Fonte: Data Rio/ Instituto Pereira Passos.

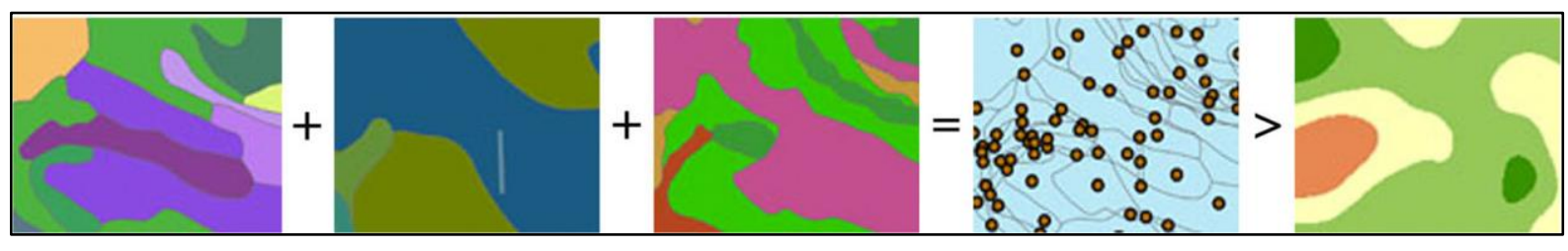

Figura 6-Procedimento ilustrativo para quantificação de geodiversidade, usando operações espaciais de sobreposição, atribuição de pontos para todos os novos polígonos e representação por kernel (FORTE, 2014).

Cabe salientar que neste método são utilizadas as três variantes principais para análise quantitativa em geodiversidade: geologia, geomorfologia e pedologia, 
conforme destaca Forte (2018), porém pode se considerar outros elementos como a hidrografia, entre outros. $\mathrm{O}$ autor ainda ressalta que "caso se exclua uma destas 3 variáveis de primordial importância, e se incluam outras mais, está a criar-se erroneamente uma distorção, em termos de densidade de pontos, que acabará inevitavelmente por enviesar a análise” (pág. 219).

$\mathrm{Na}$ presente pesquisa, foram produzidos dois mapas de índice de geodiversidade. $\mathrm{O}$ primeiro considerando as três variantes primordiais e estruturas, e o segundo inclui a hidrografia. A representação do índice pela densidade de Kernel se utilizou o número de célula 15 e de raio 1500, após vários testes para obter a melhor representação do fenômeno. Soares Filho (2019) também utilizou a combinação citada para o Parque Estadual da Pedra Branca (RJ). A intenção foi analisar qual mapa é o mais adequado para a proposta do estudo, pois há diferentes escalas envolvidas.

\section{3) Trabalho de Campo}

A etapa de trabalho de campo fora realizada entre outubro e novembro de 2020, totalizando cinco dias de atividade (Quadro 4). A presente ação teve como objetivo validar o mapa geomorfológico feito anteriormente, avaliar a compartimentação do relevo, aspectos geológicos e selecionar locais candidatos a sítios de geodiversidade.

Quadro 4- Roteiro de Trabalho de Campo

\begin{tabular}{|l|l|}
\hline Data & Destinos principais \\
\hline $\mathbf{2 2} / \mathbf{1 0}$ & Mirante Excelsior, Picos Andaraí Maior, Tijuca e Tijuca Mirim \\
\hline $\mathbf{2 3 / 1 0}$ & Caminho Dom Pedro Augusto, Estrada Major Archer e Cascata Diamantina \\
\hline $\mathbf{2 9 / 1 0}$ & $\begin{array}{l}\text { Caminho da Saudade, Caminho da Barrera, Morro do Almeida e Mirante da } \\
\text { Cascatinha }\end{array}$ \\
\hline $\mathbf{2 6 / 1 1}$ & Morro da Bandeira, Pico do Conde, Morro Anhanguera e Estrada Excelsior \\
\hline $\mathbf{2 7 / 1 1}$ & Estradas da Cascatinha e dos Picos até o Restaurante Floresta \\
\hline
\end{tabular}

Foram utilizados carta topográfica, GPS, martelo geológico, bússola geológica, celular para captura de imagens e aplicativo wikiloc, para cadastramento de pontos de interesse. Estas ferramentas são essenciais para o levantamento de informações e para uma boa operação em gabinete, na qual se irá avaliar a veracidade dos dados obtidos na etapa pré-campo. Os dados gerados foram 
fotografias para avaliação e ilustração da dissertação, pontos georreferenciados de sítios de geodiversidade e áreas de possíveis contatos litológicos.

\section{4) Mapeamento Litológico}

A presente etapa se baseou previamente em informações dos mapeamentos de geológico Folha Baía de Guanabara (Valeriano et al., 2009; 2012) e do Estado do Rio de Janeiro (HEILBRON et al., 2016). Posteriormente com a realização do trabalho de campo, fora realizada coleta de pontos em GPS de afloramentos, contribuindo desta forma, com a construção do mapa litológico do Alto Curso da Bacia do Rio Tijuca.

O levantamento da geologia do Rio de Janeiro ocorre desde o século XIX. Segundo Porto Jr. e Duarte (2012)

\footnotetext{
"A princípio, a geologia era descrita de forma subjetiva, estando inclusa em relatos de viajantes que, na época, podiam ser, tanto estudiosos (botânicos, naturalistas, geógrafos, por exemplo) como simples negociantes ou aventureiros que observavam o exotismo, as belezas e as riquezas do território que, por séculos, estivera protegido pela coroa portuguesa” (pág. 376).
}

Ao longo do século XIX outros levantamentos foram realizados. Destaque para os estudos mais específicos feitos pelo Barão de Von Eschewege e o naturalista Jean Rodolphe Agassiz. O primeiro publicou em 1831 análise sobre uma seção geológica entre a Baía de Guanabara e a Cidade de Uberaba, em Minas Gerais. Já Agassiz ressaltou os grandes blocos dispostos pelas encostas do Maciço da Tijuca, associando sua ocorrência a origem glacial, sendo esta teoria contestada posteriormente por seu discípulo Charles Frederick Hartt (PORTO JR. e DUARTE, 2012).

No século XX ocorreram ações para a continuidade de levantamentos e mapeamento do Município e entorno, através de diferentes instituições e em diferentes momentos (tabela 3). Everardo Backhauser, foi o primeiro a realizar o mapa geológico do antigo Distrito Federal (atual Município do Rio de Janeiro). Alberto Ribeiro Lamego contribuiu em diversos estudos geológicos e geográficos. No livro "O Homem e a Guanabara" (1964), o autor realizou uma avaliação sistêmica sobre a organização do relevo e geologia e como a sociedade se apropriou destes elementos. 
A publicação de mapa geológico na escala 1:50.000 de Helmbold et al. (1965 apud PORTO JR \& DUARTE, 2012) é considerada um grande marco, pois apresentou maiores informações. Já nas áreas pertencentes e adjacentes ao Maciço da Tijuca, há destaque para Gaglianone (1971) produziu levantamento e análise das Serras do Engenho Novo, Borel e Sumaré, fornecendo dados importantes sobre parte da Zona Norte Carioca. De acordo com Porto Jr. (2012) no início da década de 1980 as Universidades assumem a responsabilidade de levantamentos do Município, destacando estudos no Maciço da Tijuca com o trabalho de Pires (1982). Pires e Heilbron (1989) avaliaram a organização dos gnaisses no Maciço e em outras partes da Cidade. Sobreira (1989) realiza estudo de caso na Favela do Vidigal, na qual investigou as encostas ocupadas desordenadamente e gerando o mapa geológico-geotécnico.

A Serra da Carioca fora alvo de investigações e mapeamento por Eirado Silva et al. (1991). Tal estudo apresentou produto cartográfico na escala 1:10.000, contribuindo assim, no detalhamento das investigações. O setor Sudeste do Rio de Janeiro foi mapeado por Heilbron et al. (1993), envolvendo os morros e serras da Zona Sul, Serra do Engenho Novo e a maior parte do Maciço da Tijuca. Tal trabalho avançou no detalhamento das informações, apresentando escala 1:10.000 e nomenclatura das rochas ao invés de suíte, complexo e grupo. Já Silva et al. (2001), construíram o mapa simplificado da parte Sudeste do Rio de Janeiro com base em Helmbold et al. (1965) e Heilbron et al. (1993). Este último se mostra importante, pois houve a coloração das litologias e junção das informações de dois artigos altamente relevantes.

Em 2009, há nova ação e refinamento de informação da cartografia geológica da Folha Baía de Guanabara (VALERIANO et al., 2009) na escala 1:100.000, realizada através da parceria entre UERJ e CPRM. 
Tabela 2- Levantamentos geológicos prévios que abrangem o Maciço da Tijuca e/ou Rio de Janeiro. Adaptado de Valeriano et al. (2012).

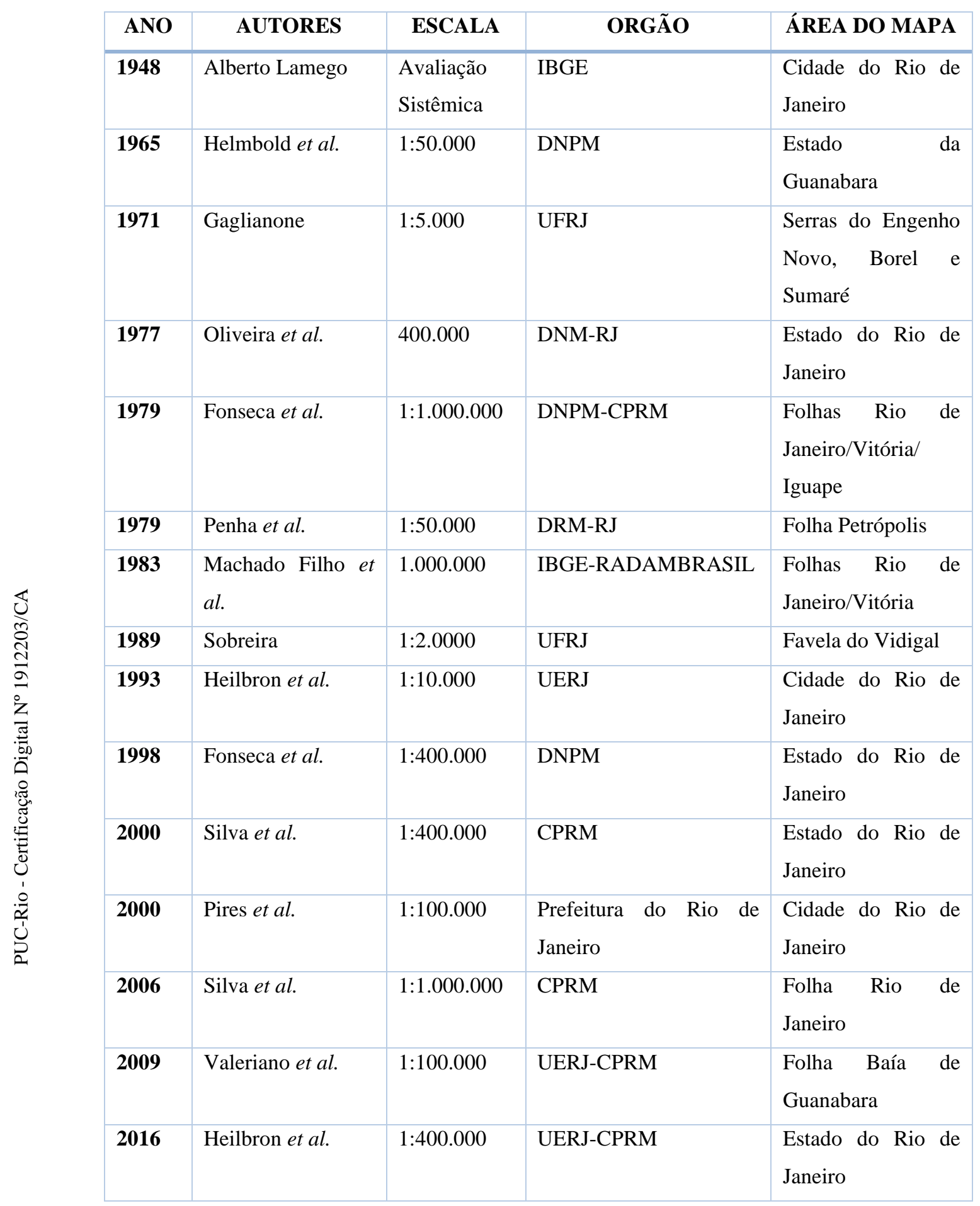

A tentativa de construir o mapa litológico de parte da Floresta da Tijuca é de contribuir com a promoção concreta do geoturismo e a geologia é a base para o entendimento da geodiversidade. 


\section{5) Inventário de Sítios de Geodiversidade}

A última etapa teve como propósito identificar e descrever áreas relevantes para a promoção do geoturismo, denominadas sítios de geodiversidade, dentro do limite de estudo principal, a bacia de drenagem do rio Tijuca (setor Floresta da Tijuca). Tal ação está vinculada a uma prática de geoconservação e auxilia diretamente nas atividades geoturísticas, pois a presente área de investigação possui fluxo intenso de turistas e é uma unidade de conservação. As ações feitas nesta etapa foram divididas em trabalho de campo, listagem em planilha e descrições gerais.

Para esta fase, será aplicada a proposta de Brilha (2016), baseada na inventariação de geossítios e sítios de geodiversidade e analisar o valor e serviços como proposto por Gray (2013). Cabe ressaltar que as estratégias de geoconservação vão além do inventário, as demais são a quantificação, classificação, conservação, valorização, divulgação e monitorização (BRILHA, 2005). Para Brilha (2016) os Geossítios estão vinculados a uma perspectiva científica, enquanto os Sítios de Geodiversidade, possuem valores culturais, turístico e educacionais. Para os geossítios há inicialmente uma avaliação qualitativa, baseada em quatro tópicos: representatividade, integridade, raridade e conhecimento científico. Posteriormente será realizada a etapa de quantificação, através de uma tabela com atributos, nos quais são adicionados valores. Tais valores refletem o grau de importância, conservação, degradação entre outras características. Para os sítios de geodiversidade também há os dois tipos de avaliação, porém a perspectiva qualitativa é fundamentada em duas perspectivas: potencial valor educacional e turístico. Para o primeiro quatro pontos são analisados:

1. Potencial didático

2. Diversidade geológica

3. Acessibilidade

4. Segurança

Para o potencial turístico se atribui também quatro tópicos:

1. Cenário

2. Potencial interpretativo

3. Acessibilidade

4. Segurança 
Para a etapa de quantificação, Brilha (2016) elenca em uma tabela diversos aspectos a serem considerados na avaliação (Tabela 3). Nesta pesquisa, foi utilizada a tabela do aplicativo Geossit da CPRM- Serviço Geológico do Brasil (https://www.cprm.gov.br/geossit/), que utiliza tal metodologia com adaptações de Cortés e Urquí (2009) e de Brilha (2016) (Tabelas 4, 5, 6, 7 e 8).

Tabela 3: Parâmetros utilizados na quantificação de geossítios e sítios de geodiversidade com potencial educacional e turístico. Adaptado de Brilha (2016)

\begin{tabular}{|c|c|c|c|c|c|}
\hline Geossítios & Peso & $\begin{array}{c}\text { Potencial } \\
\text { educacional }\end{array}$ & Peso & Potencial turístico & Peso \\
\hline Representatividade & 30 & Vulnerabilidade & 10 & Vulnerabilidade & 10 \\
\hline Localidade chave & 20 & Acessibilidade & 10 & Acessibilidade & 10 \\
\hline Conhecimento científico & 5 & Limitações de uso & 5 & Limitações de uso & 5 \\
\hline Integridade & 15 & Segurança & 10 & Segurança & 10 \\
\hline Diversidade geológica & 5 & Logística & 5 & Logística & 5 \\
\hline Raridade & 15 & $\begin{array}{l}\text { Densidade } \\
\text { populacional }\end{array}$ & 5 & $\begin{array}{l}\text { Densidade } \\
\text { populacional }\end{array}$ & 5 \\
\hline Limitações de uso & 10 & $\begin{array}{l}\text { Associação com } \\
\text { outros valores }\end{array}$ & 5 & $\begin{array}{l}\text { Associação com } \\
\text { outros valores }\end{array}$ & 5 \\
\hline & & Cenário & 5 & Cenário & 15 \\
\hline & & Singularidade & 5 & Singularidade & 10 \\
\hline & & $\begin{array}{l}\text { Condições de } \\
\text { observação }\end{array}$ & 10 & $\begin{array}{l}\text { Condições de } \\
\text { observação }\end{array}$ & 5 \\
\hline & & Potencial didático & 20 & $\begin{array}{c}\text { Potencial } \\
\text { interpretativo }\end{array}$ & 10 \\
\hline & & \multirow{2}{*}{$\begin{array}{l}\text { Diversidade } \\
\text { Geológica }\end{array}$} & \multirow[t]{2}{*}{10} & Nível econômico & 5 \\
\hline & & & & $\begin{array}{c}\text { Proximidade de áreas } \\
\text { recreativas }\end{array}$ & 5 \\
\hline Total & 100 & \multicolumn{2}{|l|}{100} & \multicolumn{2}{|l|}{100} \\
\hline
\end{tabular}

Tabelas 4, 5, 6, 7 e 8: Cálculo de quantificação de geossítios e sítios de geodiversidade. Fonte: site geossit da CPRM- Serviço geológico do Brasil (https://www.cprm.gov.br/geossit/).

4) Valor Científico

\begin{tabular}{|c|c|c|}
\hline & Critério & Nota \\
\hline A1 & Representatividade & Peso \\
\hline A2 & Local-tipo & $30 \%$ \\
\hline A3 & Conhecimento científico & $20 \%$ \\
\hline A4 & Integridade & $5 \%$ \\
\hline A5 & Diversidade geológica & $15 \%$ \\
\hline A6 & Raridade & $5 \%$ \\
\hline A7 & Limitações ao uso & $15 \%$ \\
\hline & Total & $10 \%$ \\
\hline
\end{tabular}


5) Risco de Degradação

\begin{tabular}{|c|c|c|}
\hline \multicolumn{1}{|c|}{ Critério } & Nota & Peso \\
\hline B1 & Deterioração de elementos geológicos & $35 \%$ \\
\hline B2 & Proximidade a áreas/atividades com potencial para causar degradação & $20 \%$ \\
\hline B3 & Proteção legal & $20 \%$ \\
\hline B4 & Acessibilidade & $15 \%$ \\
\hline B5 & Densidade populacional & $10 \%$ \\
\hline & Total & $\mathbf{1 0 0 \%}$ \\
\hline
\end{tabular}

6) O Risco de Degradação (RD), pode ser classificado em três níveis: baixo, médio, alto.

\begin{tabular}{|c|c|}
\hline Valor final & Risco de degradação \\
\hline $0<=$ Valor $<=200$ & Baixo \\
\hline $200<$ Valor $<=300$ & Médio \\
\hline $300<$ Valor $<=400$ & Alto \\
\hline
\end{tabular}

7) Potencial Uso Educativo e Turístico

\begin{tabular}{|c|c|c|c|c|}
\hline \multirow[t]{2}{*}{ Critério } & & \multicolumn{2}{|r|}{ Educativo } & Turístico \\
\hline & & Nota & Peso & Peso \\
\hline $\mathrm{C} 1$ & Vulnerabilidade & & $10 \%$ & $10 \%$ \\
\hline $\mathrm{C} 2$ & Acessibilidade & & $10 \%$ & $10 \%$ \\
\hline $\mathrm{C} 3$ & Limitações ao uso & & $5 \%$ & $5 \%$ \\
\hline $\mathrm{C} 4$ & Segurança & & $10 \%$ & $10 \%$ \\
\hline C5 & Logística & & $5 \%$ & $5 \%$ \\
\hline C6 & Densidade populacional & & $5 \%$ & $5 \%$ \\
\hline $\mathrm{C} 7$ & Associação com outros valores & & $5 \%$ & $5 \%$ \\
\hline $\mathrm{C} 8$ & Beleza cénica & & $5 \%$ & $15 \%$ \\
\hline C9 & Singularidade & & $5 \%$ & $10 \%$ \\
\hline $\mathrm{C} 10$ & Condições de observação & & $10 \%$ & $5 \%$ \\
\hline $\mathrm{C} 11$ & Potencial didático & & $20 \%$ & \\
\hline $\mathrm{C} 12$ & Diversidade geológica & & $10 \%$ & \\
\hline $\mathrm{C} 13$ & Potencial para divulgação & & & $10 \%$ \\
\hline C14 & Nível econômico & & & $5 \%$ \\
\hline $\mathrm{C} 15$ & Proximidade a zonas recreativas & & & $5 \%$ \\
\hline
\end{tabular}


8) Prioridade de Proteção

\begin{tabular}{|c|c|c|c|}
\hline Pelo Interesse & \multicolumn{2}{|c|}{ Valor } & \multicolumn{2}{c|}{ Risco de degradação } & \\
\hline Científico (lc) & & & \\
\hline Didático (ld) & & + & \\
\hline Turístico (lt) & & & \\
\hline Global $(\mathrm{lg}) *$ & & & \\
\hline
\end{tabular}

\begin{tabular}{|c|c|}
\hline Soma & Prioridade de Proteção \\
\hline $0<=$ Soma $<=300$ & A longo prazo \\
\hline $300<$ Soma $<=550$ & A médio prazo \\
\hline $550<$ Soma $<=750$ & A curto prazo \\
\hline $750<$ Soma $<=800$ & Urgente \\
\hline
\end{tabular}

Neste trabalho é feita a seleção e descrição de sítios, com foco para o turismo. A aplicação ao geoturismo do Parque Nacional da Tijuca, tendo com área laboratório o alto curso da bacia do rio Tijuca, resultará da análise integrada entre os mapas geomorfológico e litológico índice de geodiversidade e levantamento de sítios, no qual visará ações que contribuam de forma concreta na gestão territorial e ambiental do Parque. 


\section{5) Resultados e Discussões}

\section{1) Cartografia Geomorfológica e Geodiversidade do Maciço da}

Tijuca

\subsection{1) Contexto Geológico e Geomorfológico}

O Maciço da Tijuca encontra-se geologicamente contextualizado na porção central da Faixa Móvel Ribeira (figura 7). Segundo Almeida et al. (1973), esta faixa de dobramentos constitui uma entidade geotectônica do Neoproterozoico, com formação que remonta a orogênese Brasiliana/Pan-africana, em que ocorreram processos convergentes em margens ativas (Margens Continentais do Tipo Pacífico), há aproximadamente 560 milhões de anos. Tal evento se caracterizou pela amalgamação do supercontinente Gondwana. Tal faixa representa um dos orógenos da província Mantiqueira (ALMEIDA et al., 1981)

De acordo com Heilbron et al. (2004), esta província é um sistema orogênico neoproterozoico, na qual engloba as faixas Araçuaí, Ribeira, Brasília meridional, Dom Feliciano e São Gabriel, se desenvolvendo entre o sul do Estado da Bahia até o Rio Grande do Sul. 


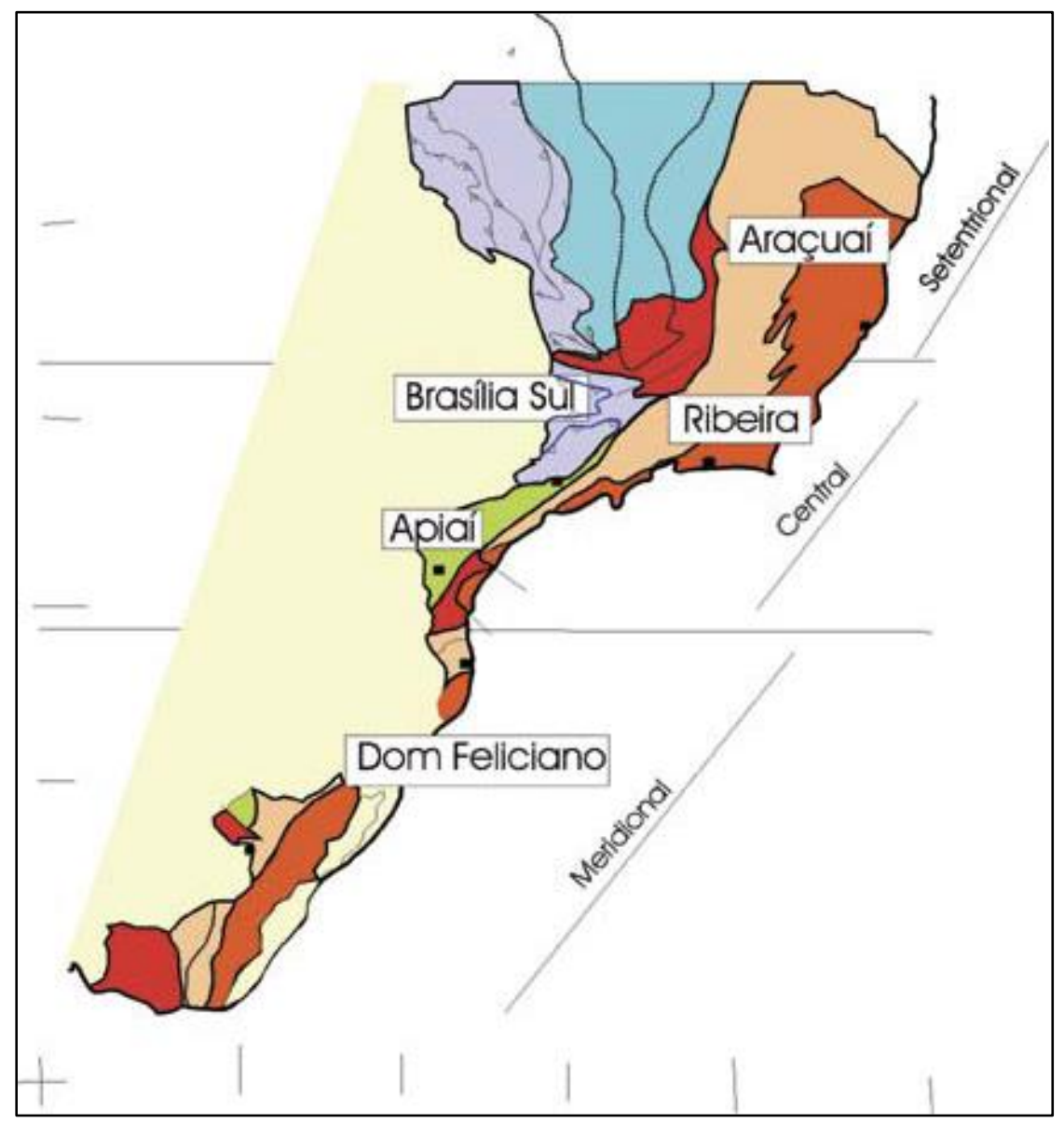

Figura 7: Subdivisão do Sistema Orogênico Mantiqueira: o segmento setentrional é o Orógeno Araçuaí; o segmento central inclui a porção sul do Orógeno Brasília e os orógenos Ribeira e Apiaí; e o segmento meridional inclui os orógenos Dom Feliciano e São Gabriel. As cores roxo e laranja indicam os terrenos que alojam os arcos magmáticos neoproterozóicos (HEILBRON et al., 2004, pág. 207).

A Faixa Ribeira apresenta uma direção estrutural de seus terrenos alinhada NE-SW de forma marcante (figura 8). Segundo Heilbron et al. (2004), este cinturão resultou da interação entre o Cráton do São Francisco e outra(s) placas e/ou microplaca(s) e/ou arco de ilhas, bem como com a porção sudoeste do Cráton do Congo. A Faixa está dividida entre quatro terrenos tectono-estratigráficos em sua porção central: Ocidental, Oriental, Central e Cabo Frio. Os três primeiros foram amalgamados entre ca. 605 e 570 Ma e o último entre ca. 530 a 510 Ma (Heilbron et al., 2012). Cada terreno é subdividido em domínios. 


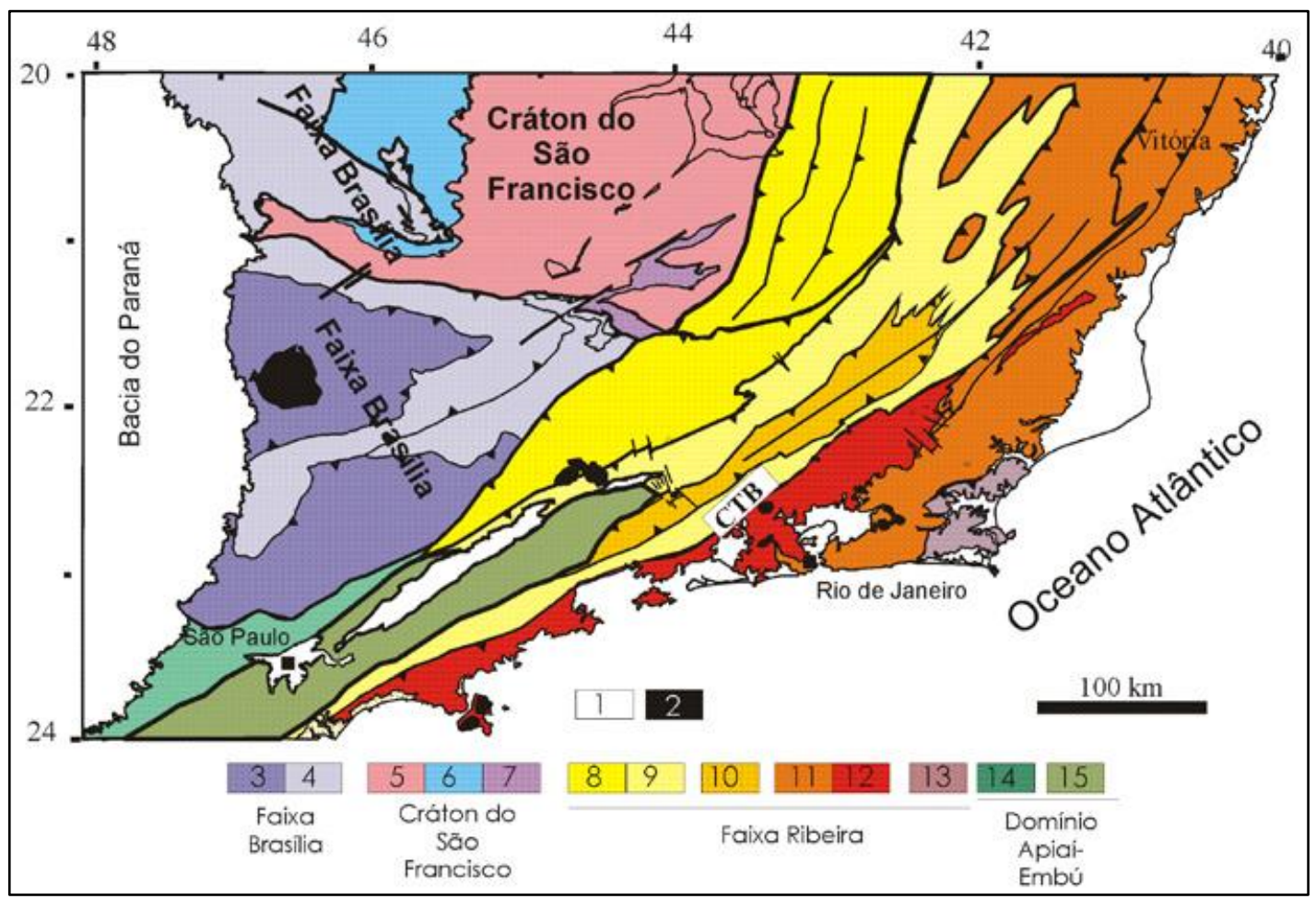

Figura 8: Compartimentação tectônica da Região SE brasileira (dados de Heilbron et al., 2004). Legenda: 1- para os terrenos da Faixa Ribeira: 8 e 9 - Domínios Andrelândia e Juiz de Fora do Terreno Ocidental; 10- Terreno Paraíba do Sul; 11 e 12 - Terreno Oriental, com o Arco Magmático Rio Negro discriminado (11); 13 - Terreno Cabo Frio. Fonte: Heilbron et al. (2004).

Após o fim desse evento tectônico e a relativa estabilidade crustal que se seguiu durante o Paleozoico, no Jurássico e Cretáceo se desenvolveu o processo de abertura do Oceano Atlântico e quebra do continente Gondwana. Entre diversas atividades e fases desse processo de abertura, no Cretáceo Superior, o processo de quebra do continente instalou o Sistema de Rifts Cenozoicos do Sudeste do BrasilSRCSB (ZALÁN e OLIVEIRA, 2005). Segundo os autores, a região Sudeste do Brasil não se constituiu de forma alguma, em uma típica margem passiva (Margem Continental do Tipo Atlântica) tal como preconizada na visão clássica da Teoria de Placas.

Tal compartimento fora anteriormente denominada por Almeida (1976) como Sistemas de Rifts da Serra do Mar e posteriormente definida por Riccomini (1989) como Rift Continental do Sudeste do Brasil. De acordo com Riccomini et al. (2004), esta feição se desenvolve entre o Município de Curitiba (PR) e o distrito de Barra de São João, localizado em Casemiro de Abreu (RJ). A feição é marcada pela presença das bacias tafrogênicas de Curitiba, São Paulo, Taubaté, Resende, Volta Redonda e Itaboraí, assim como pelo Gráben da Guanabara (figura 9). 
Esta última, alvo de estudos importantes como os de Almeida (1976), Asmus e Ferrari (1978) e Ferrari (2001), foi redefinida por Zalán (2004), como se alongando por cerca de 210 km na direção ENE-OSO, desde Paraty até Rio Bonito, extremo leste da Região Metropolitana do Rio de Janeiro. A formação destas feições se dá pela quebra do supercontinente Gondwana e abertura do Oceano Atlântico, contribuindo para formação dos maciços litorâneos, que de acordo com Azevedo Júnior (1991 apud Ferrari, 2001) corresponderiam a um relevo residual, associado a litologias mais resistentes e/ou a áreas sem a atuação de drenagens importantes. Outro importante destaque é a presença de rochas ígneas instaladas em diques toleíticos e alcalinos, assim como em plugs alcalinos, como os de Poços de Caldas, Itatiaia, Morro Redondo, Tinguá, Medanha, Tanguá/Rio Bonito e Morro de São João.

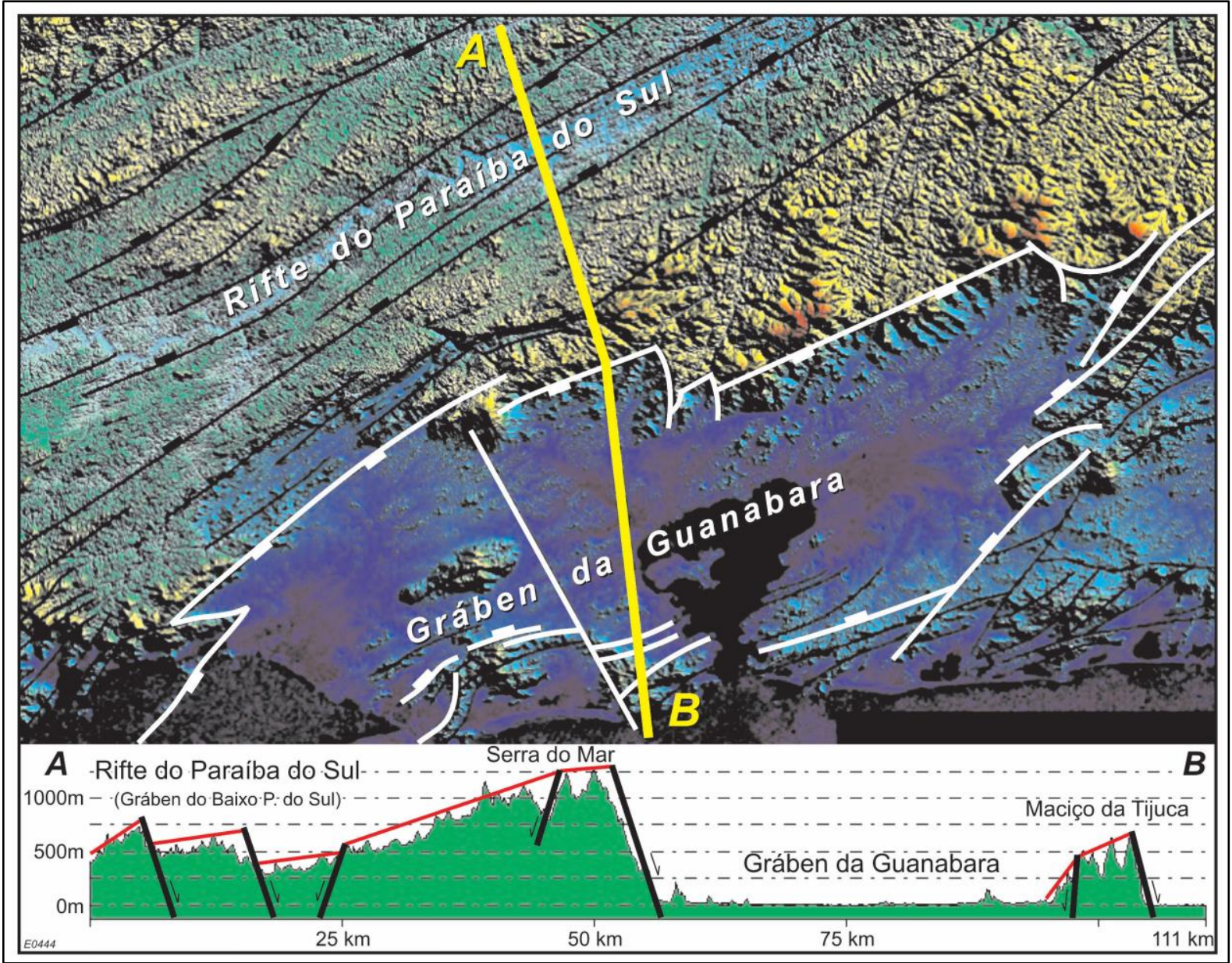

Figura 9: Perfil morfo-estrutural interpretado do Gráben da Guanabara, assimétrico com borda falhada (Serra do Mar) e borda flexural (Maciço da Tijuca). Por uma questão de simplificação, nem todas as falhas do mapa foram indicadas no perfil. Linha vermelha no perfil representa uma interpretação da atitude atual da Superfície de Aplainamento Japi (ZALÁN \& OLIVEIRA, 2005). 
De acordo com a Almeida e Carneiro (1998) a formação da Serra do Mar remonta provavelmente o Paleoceno. Ainda de acordo com os autores tal feição se caracteriza como um conjunto de escarpas festonadas com cerca de $1.000 \mathrm{~km}$ de extensão, em que termina o Planalto Atlântico no trecho voltado para a Bacia de Santos. Ela se estende do Rio de Janeiro ao norte de Santa Catarina. Já Penha (2015), salienta que se trata de uma escarpa de falha recuada pela erosão remontante, cuja formação iniciada no final do Cretáceo vem se desenvolvendo durante todo Cenozóico.

O Maciço da Tijuca, onde está localizada a área do presente estudo, configura-se como um maciço isolado remanescente do horst limítrofe da borda sul do gráben da Guanabara. No Maciço da Tijuca (figura 10) há a presença de ortognaisses, granitóides e sequências metassedimentares de alto grau vinculados ao domínio costeiro do terreno oriental da Faixa Ribeira. De acordo com Lobato (2013), tal domínio é caracterizado por abrigar rochas ortoderivadas com afinidade de arcos magmáticos, pertencentes ao Complexo Rio Negro (ca 605 a $450 \mathrm{Ma}$ ), apresentando assinatura de ambientes de zonas de subducção e encaixadas por rochas metassedimentares do Grupo São Fidélis. Há também granitóides sin a tardi colisionais intrudidos nessas litologias. 


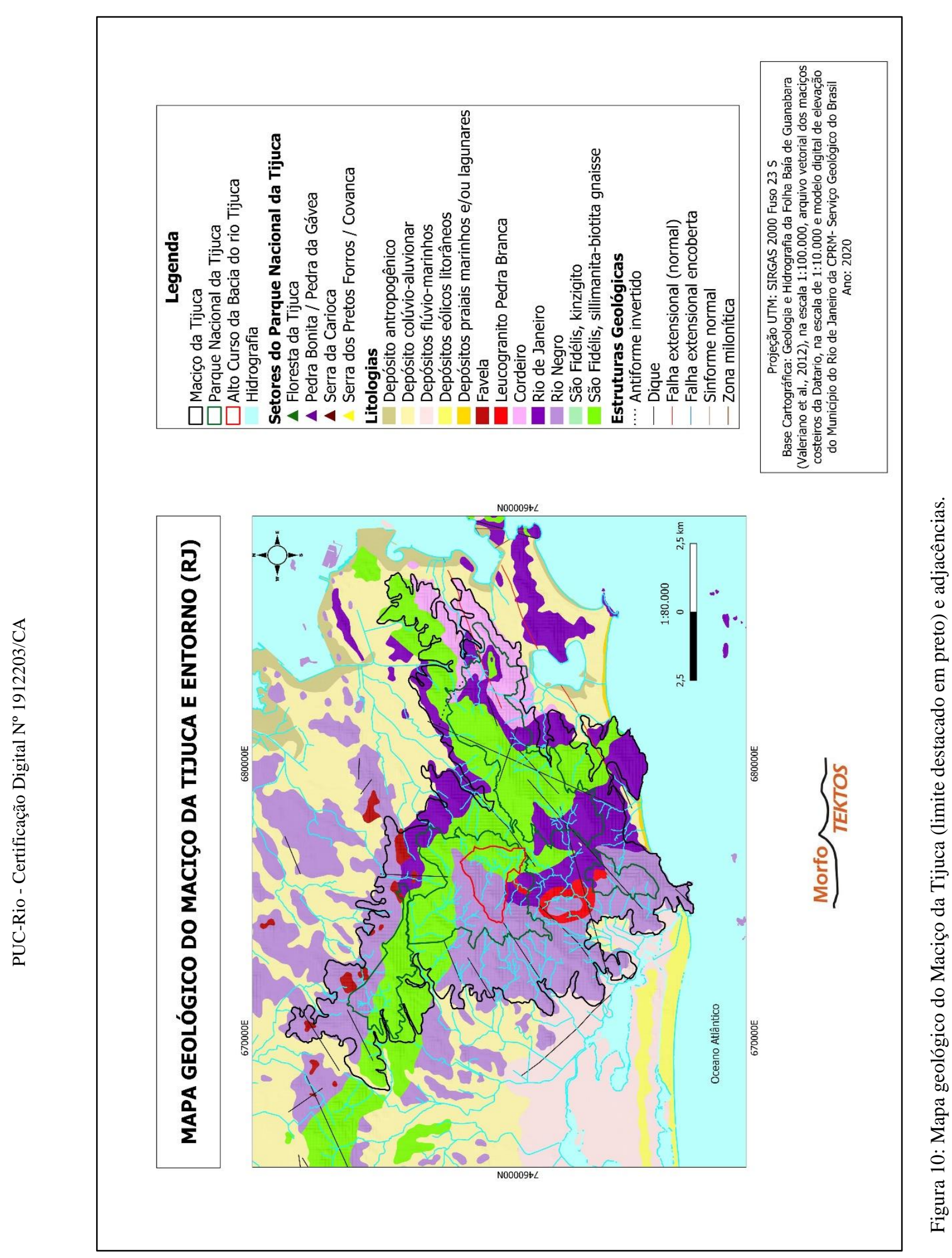


De acordo com Valeriano et al. (2012) ocorrem em dois tipos de rochas paraderivadas do grupo São Fidélis: silimanita granada biotita gnaisse e kinzigito. A primeira tipologia é caracterizada pela predominância de sillimanita-granada biotita gnaisse, com lentes de quartzito feldspáticos e calciosilicáticas. Já no kinzigito predominam cordierita-sillimanita-granada-biotita gnaisses escuros, sendo também gnaisses, com característica homogênea ou finamente estratificados, com veios leucossomáticos e lentes calciossilicáticas (Valeriano et al., 2012).

Os ortognaisses do Complexo Rio Negro (pré colisionais) apresentam composição básica a intermediária e evolução policíclica com complexa estruturação (VALERIANO et al., 2012). No Maciço da Tijuca sua ocorrência é marcada pelo Gnaisse Archer, sendo subdividido em plagioclásio gnaisse e microclina gnaisse. O plagioclásio gnaisse se caracteriza pela presença de quartzo dioritos a granodioritos em sua composição, tons escuros, polideformadas, migmatizadas, com interdigitações de bandas anfibolíticas e ampla variação de textura (VALERIANO et al., 2012). O segundo litotipo possui composição que varia de granodiorítica a granítica, bandamento, diferentes texturas, veios pegmatíticos e porfiroclastos de microclina (VALERIANO et al., 2012).

As litologias sin a pós colisionais são representadas pelas Suítes Rio de Janeiro, Cordeiro, Suruí e Nova Friburgo. A Suíte Rio de Janeiro é marcada pela ocorrência do gnaisse facoidal (augen gnaisse). Valeriano et al. (2012) descrevem essa unidade como sendo uma composta por uma rocha com megacristais de microclina com formas amendoadas $(3 \mathrm{a} 5 \mathrm{~cm}$ ) em matriz granítica rica em biotita, podendo conter teores expressivos de granada e hornblenda e minerais acessórios que incluem biotita, zircão, apatita, magnetita e ilmenita. A Suíte Cordeiro é um conjunto de ortognaisses, de acordo com Valeriano et al. (2012), que possuem origem anatética concomitante à deformação principal de baixo ângulo de mergulho.

No Maciço da Tijuca essa unidade é representada pelo leptinito, que segundo Vasconcellos (2011), é um gnaisse leucocrático, com teor de sílica acima de 65\% (ácido), com grão fino até médio, escassamente folheado, sendo comumente encontrado com textura grosseira ou cortado por pegmatitos e aplitos. Sua mineralogia é caracterizada pela ocorrência predominante de quartzo, feldspatos alcalinos e plagioclásio e quantidade menores de biotita e granada. Sua extensão ocorre entre os bairros de Santa Teresa e Jardim Botânico. A Suíte Suruí é vinculada 
a um conjunto de granitos tardi colisionais. $\mathrm{Na}$ área de investigação é representado pelo granito Pedra Branca, caracterizado por uma textura porfirítica, rico em megacristais de microclima pertítica em matriz monzogranítica (VALERIANO et al., 2012). Já a suíte Nova Friburgo é um conjunto de granitoides intrusivos não deformados, tendo na área de estudo a presença do Granito Favela (PIRES et al., 1982 apud VALERIANO et al., 2012). São caracterizados pela homogeneidade, cor cinza, texturas equigranulares a pofiríticas e algumas ocorrências de allanita.

Sobre o contexto geomorfológico, Dantas (2000) apresentou o Mapa Geomorfológico do Estado do Rio de Janeiro, dividindo em unidades morfoestruturais e morfoesculturais. A presente área de estudo se encontra na unidade morfoestrutural Cinturão Orogênico do Atlântico, que compreende formas de relevo de um conjunto diversificado de rochas metamórficas e ígneas de idade pré-cambriana a eopaleozóica. A unidade morfoescultural presente é denominada maciços costeiros e interiores. De acordo com Dantas (2000)

\begin{abstract}
"compreende um conjunto de maciços montanhosos relativamente alinhados sob direção WSW-ENE, desde o Maciço da Juatinga ao maciço da Região dos Lagos, estando situados em meio às baías e baixadas litorâneas. Foram inseridos também nessa unidade os maciços ou os alinhamentos serranos situados em posição de contrafortes da escarpa da Serra do Mar, tais como os maciços de Suruí e Conceição de Macabu" (pág. 11).
\end{abstract}

De acordo com o mapa geomorfológico de Dantas (2019), são encontradas as unidades serrano, morros baixos, morros altos e baixos, morrotes, rampas de colúvio/depósito de tálus e rampas de alúvio-colúvio (figura 11). 


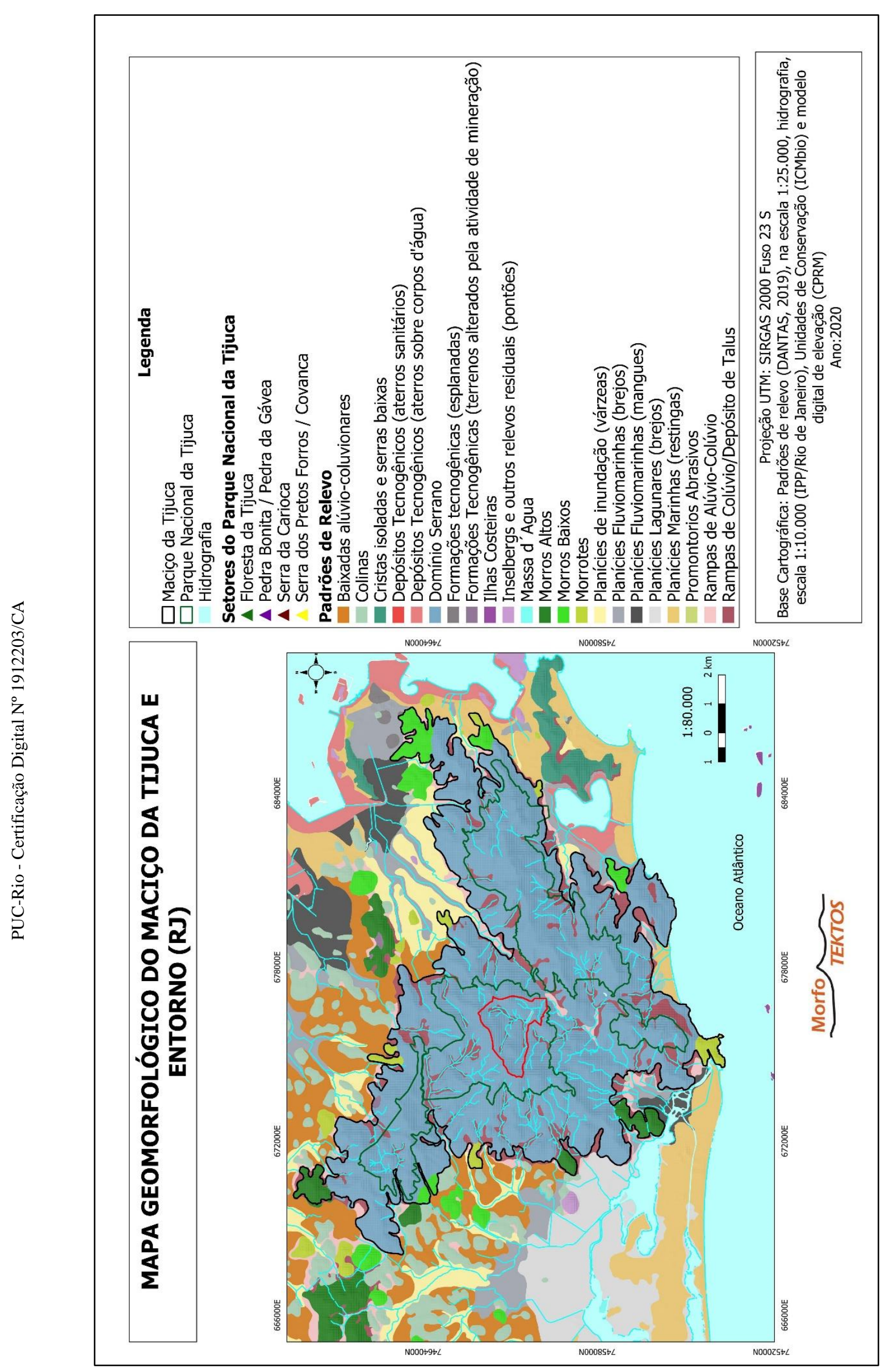

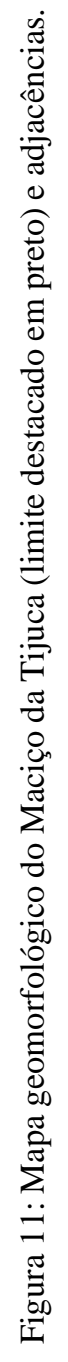


O complexo conjunto litoestrutural do Maciço da Tijuca se traduz em diversas feições geomorfológicas, ora mais resistentes e ora menos resistentes aos processos erosivos. A presença de diques contribuiu no desenvolvimento de vales, as falhas normais auxiliaram na ocorrência de vertentes abruptas com alta declividade e forte suscetibilidade a movimentos de massa, com riscos de desastres. Outro destaque se dá pela ocorrência de picos, como da Tijuca (Figura 12), Papagaio, Conde, Pedra da Gávea e Bonita e knickpoints, como a cascatinha de Taunay, nos quais refletem a resistência litológica e ajustes do nível de base.

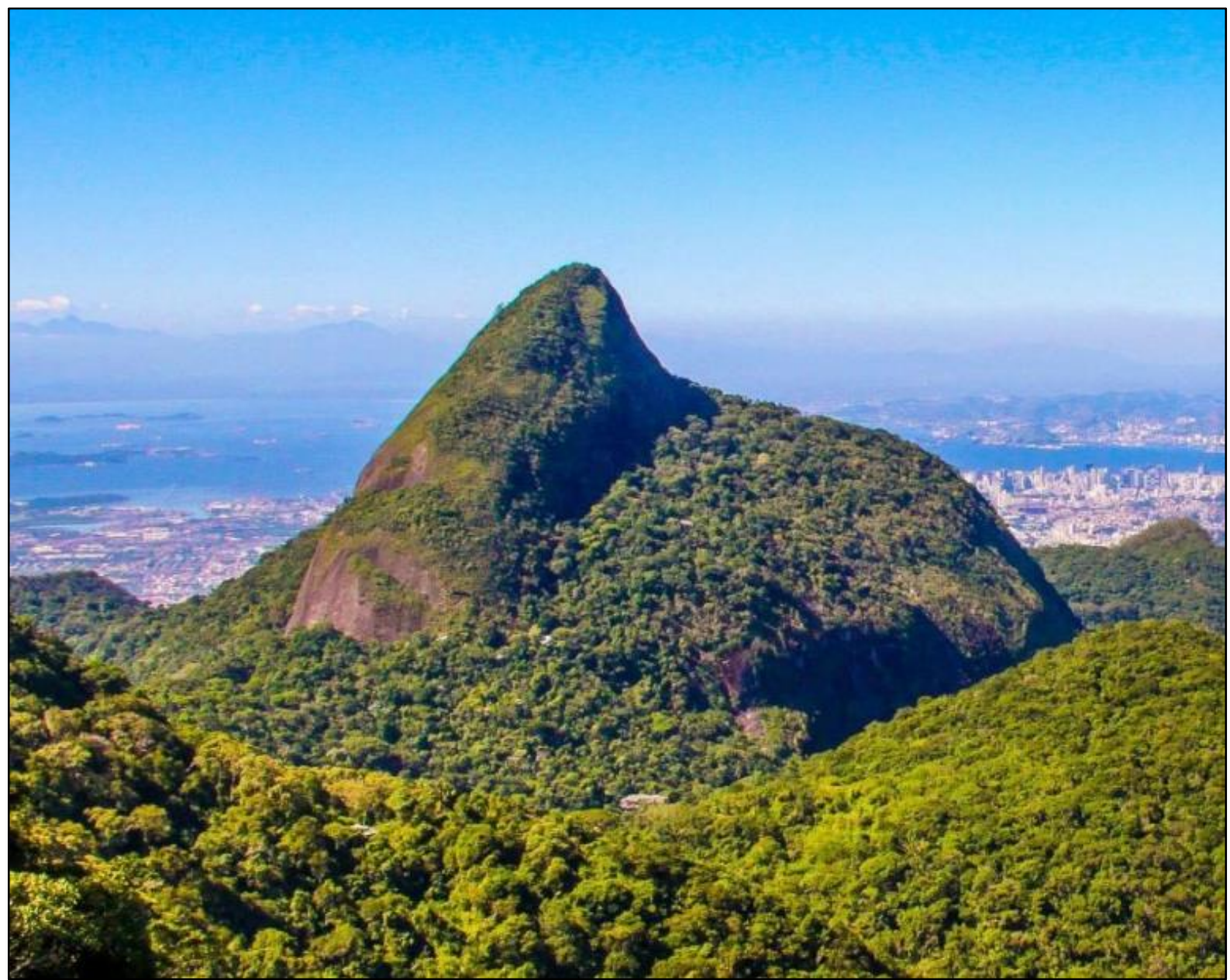

Figura 12: Vista do Pico da Tijuca com Baía da Guanabara e Serra do Mar ao Fundo. Fonte: Destinos do Rio.Disponível em: <https://www.destinosdorio.com.br/cidades/rio-de-janeiro/naturezaegeografia/montanhas/item/266-o-ponto-culminante-da-cidade-do-rio-de-janeiro-e-o-pico-datijuca-com-1021m-de-altitude> Acesso em 04/06/2020.

Segundo Coelho Netto (2005) o Maciço da Tijuca apresenta morfologia assimétrica, suas amplitudes de relevo e gradientes topográficos não possuem uniformidade espacial. Ainda de acordo com a autora, juntas de alívio, falhas e 
fraturas influenciam o intemperismo diferencial das rochas, no qual gerou a formação de blocos in situ. As drenagens principais percorrem as falhas e fraturas geradas pelos intensos processos geológicos mencionados anteriormente. $\mathrm{O}$ vale que divide as bacias dos rios Maracanã e Cachoeira, se destaca por ser um lineamento estrutural formado por dique e fraturas, pelas inflexões dos rios Maracanã e Tijuca e divide o maciço em Serra da Carioca e Serra da Tijuca.

Muitas encostas que bordejam o maciço foram e ainda são marcadas pelas ocupações irregulares e falta de planejamento territorial. A ocorrência de movimentos de massa é um fator preocupante e recorrente, sobretudo no verão, com forte ação das chuvas. Segundo Fernandes et al. (2006)

\begin{abstract}
"a transformação contínua da paisagem contribui para a modificação do comportamento hidrológico, caracterizando o desenvolvimento de condições favoráveis ao aumento de processos erosivos por diferentes mecanismos, e conseqüentemente, contribuindo para um aumento das descargas líquidas e sólidas nos canais fluviais. Durante os eventos pluviométricos mais intensos, essas descargas tornam-se maiores e mais rápidas, gerando mais freqüentemente às inundações nas porções inferiores dos vales e baixadas adjacentes. Como exemplo podemos citar os casos registrados em 1966, 1967, 1988 e 1996, que assumiram um caráter catastrófico, principalmente nas áreas habitadas por populações mais pobres, em face da carência de infraestrutura urbana, como da precariedade das construções aí localizadas".
\end{abstract}

\title{
5.1.2) Solos
}

A declividade acentuada, e o relevo predominantemente serrano, auxiliaram na formação de solos rasos no Maciço da Tijuca, onde há falta de estudos mais detalhados sobre a pedologia local (figura 13). Segundo o mapa de solos de Lumbreiras e Gomes (2004), há a presença de latossolos vermelho-amarelo e argissolos amarelo e vermelho-amarelo. De acordo com Slongo (2008), em áreas em que ocorrem associação entre latossolos e argissolos, apresentam caráter distrófico ou álico com perfis espessos. Já as que apresentam caráter eutrófico, possuem perfis rasos. Ainda de acordo com o autor, os argissolos são predominantemente cauliníticos, bem drenados e com textura média/argilosa e/ou média/ muito argilosa. Os latossolos estão relacionados a relevo forte ondulado a montanhoso e possuem textura argilosa (LUMBREIRAS e GOMES, 2004). Os cambissolos também ocorrem, porém em associação aos latossolos e sob floresta subperenifólia (LUMBREIRAS e GOMES, 2004). 


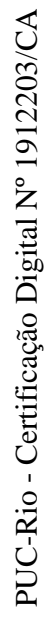
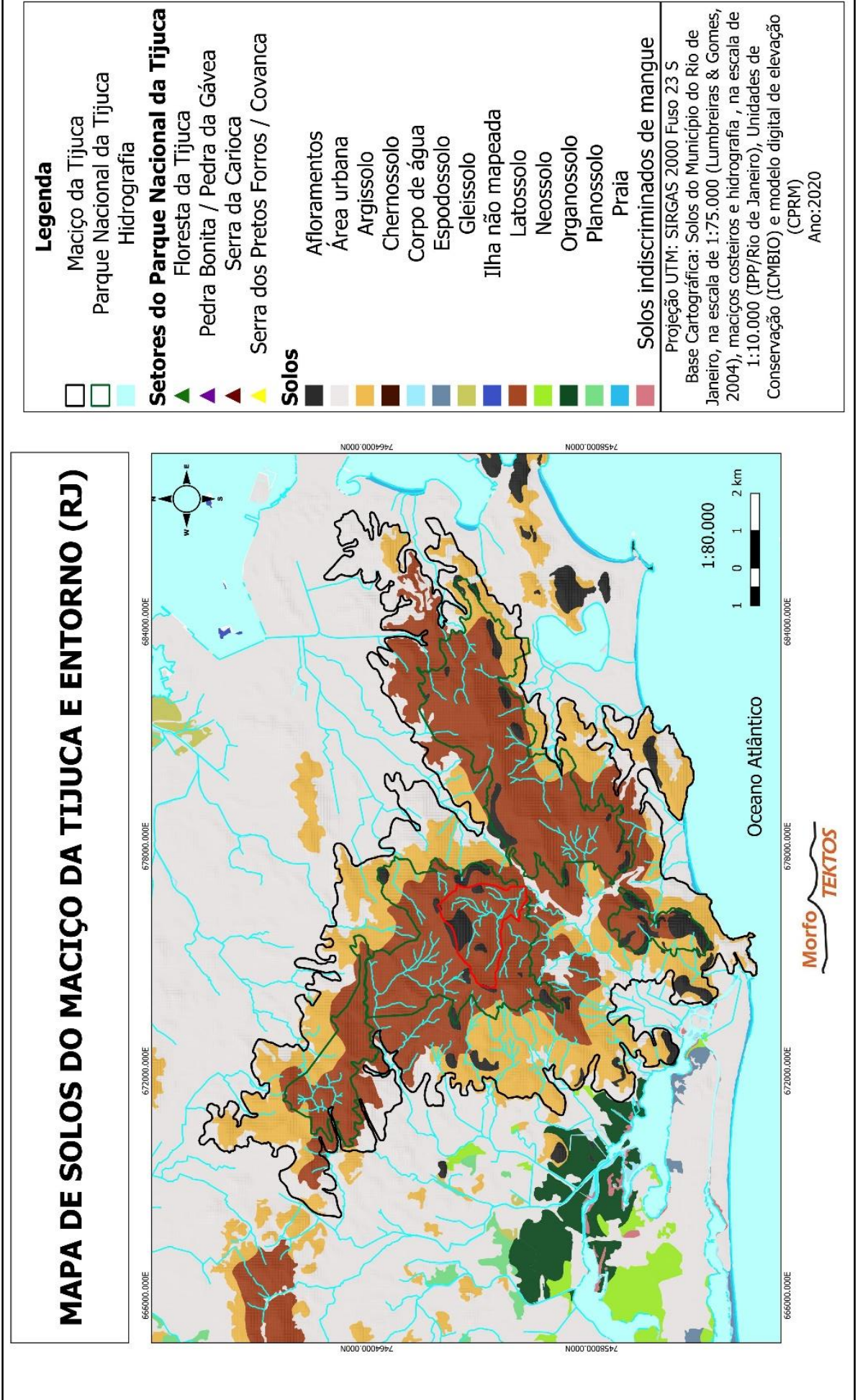

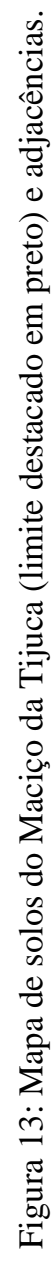




\subsection{3) Cartografia do Relevo do Maciço da Tijuca}

A hipsometria (figura 14) do Maciço da Tijuca apresenta variação de 1 a um pouco mais de 1000 metros. O mapa foi reclassificado em oito classes. Os pontos de menor altitude estão em suas bordas, no contato com as planícies fluviais e fluviomarinhas, entre as 1 a 100 metros, tendo a classe 50-100 metros com maior ocorrência $(12,10 \%)$ entre as baixas altimetrias. Já os locais de maiores cotas se concentram no centro e nordeste do maciço, tendo como destaque os picos da Tijuca, Papagaio e Cocanha no setor A do PNT, estando na cota acima de 900 metros e na classe 700 a 900 metros onde destacam-se o morro do corcovado no setor B e pedra da Gávea e Bonita no setor C.

As porções intermediárias ocorrem nas áreas que estão entre 100 a 500 metros. A classe 100-300 metros é a de maior ocorrência entre todas as classes, com $40,37 \%$ seguida de $300-500$ metros com $25,83 \%$. Estas classes representam as vertentes de transição entre as planícies e o domínio serrano, com destaque para a parte nordeste do maciço, no qual abrange como bairros Santa Teresa, Laranjeiras, Botafogo, Catete e Estácio e noroeste, onde se localiza o setor D (Serra dos Pretos Forros e Covanca), apresentando os locais com o relevo mais dissecado da área de estudo. Já as menores são 1-10 (0,09\%) e acima de 900 e 700-900 metros (0,26\%). Tais dados salientam a força dos processos morfoclimáticos, visto que as maiores classes se relacionam as partes intermediárias, enquanto os locais mais altos estão entre as menores porcentagens, aonde há maior resistência litoestrutural.

Tabela 9: Áreas em $\mathrm{km}^{2}$ e porcentagens das classes de hipsometria. Destaque em verde para as

\begin{tabular}{|c|c|c|}
\hline \multicolumn{3}{|c|}{ menores porcentagens e em rosa, para as maiores. } \\
\hline Classes & Área $\left(\mathrm{km}^{2}\right)$ & Porcentagem $(\%)$ \\
\hline $1-10$ metros & 0.10 & 0,09 \\
\hline $10-50$ metros & 4.27 & 3,84 \\
\hline $50-100$ metros & 13.44 & 12,10 \\
\hline $100-300$ metros & 44.81 & 40,37 \\
\hline $300-500$ metros & 28.68 & 25,83 \\
\hline 500-700 metros & 16.13 & 14,53 \\
\hline $700-900$ metros & 3.24 & 2,91 \\
\hline Acima de 900 metros & 0.29 & 0,26 \\
\hline
\end{tabular}




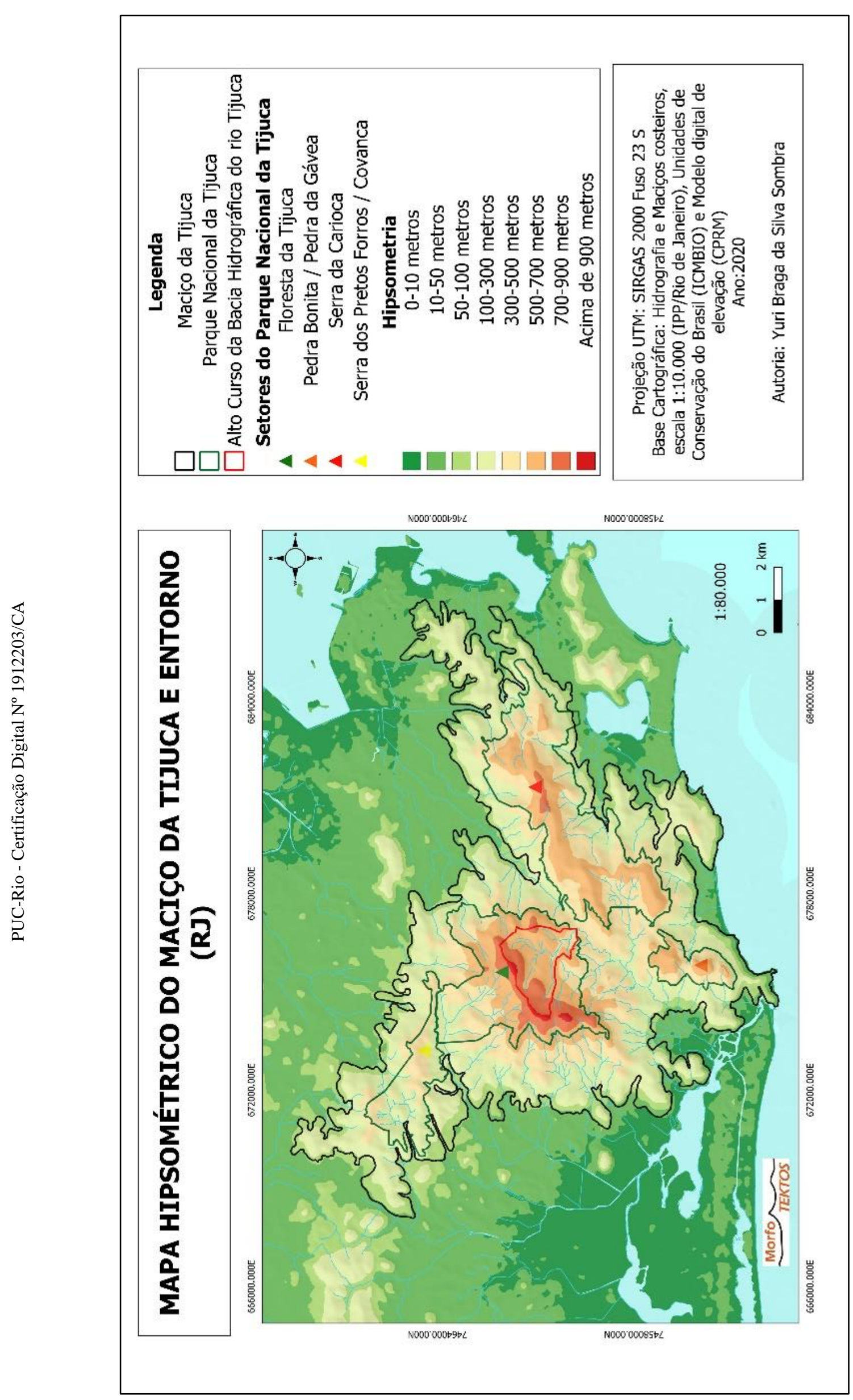

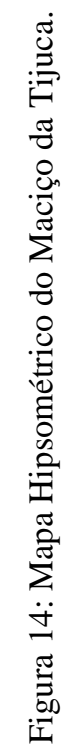


A declividade (figura 15) apresentou os sete conjuntos citados na proposta de Lepsch et al. (1991). Há maior ocorrência das categorias forte ondulado (56,16\%) e montanhoso (30,3\%), respectivamente. Já as menores inclinações estão entre as menores ocorrências, com $0,03 \%$ para plano, $0,38 \%$ para suave ondulado, $1,79 \%$ de ondulado e $3,72 \%$ em moderadamente ondulado. Tais declividades ocorrem em pequenas porções das bordas do maciço e no alto curso da bacia do rio Cachoeira, em especial nas sub bacias do rio Gávea Pequena e rio Tijuca. A classe escarpado ocorre em 7,57 \% da área de estudo e juntamente com forte ondulado e montanhoso, são as classes com maior suscetibilidade a movimentos de massa, ocorrendo predominantemente na Serra da Carioca e nos Picos da Floresta da Tijuca.

Tabela 10: Áreas em $\mathrm{km}^{2}$ e porcentagens das classes de declividade. Destaque em verde para as menores porcentagens e em rosa, para as maiores.

\begin{tabular}{|c|c|c|}
\hline Classes & Área $\left(\mathrm{km}^{2}\right)$ & Porcentagem \\
\hline Plano & 0.04 & 0,03 \\
\hline Suave ondulado & 0.42 & 0,38 \\
\hline Ondulado & 1.99 & 1,79 \\
\hline Moderadamente ondulado & 4.13 & 3,72 \\
\hline Forte ondulado & 62.34 & 56,16 \\
\hline Montanhoso & 33.64 & 30,30 \\
\hline Escarpado & 8.41 & 7,57 \\
\hline
\end{tabular}




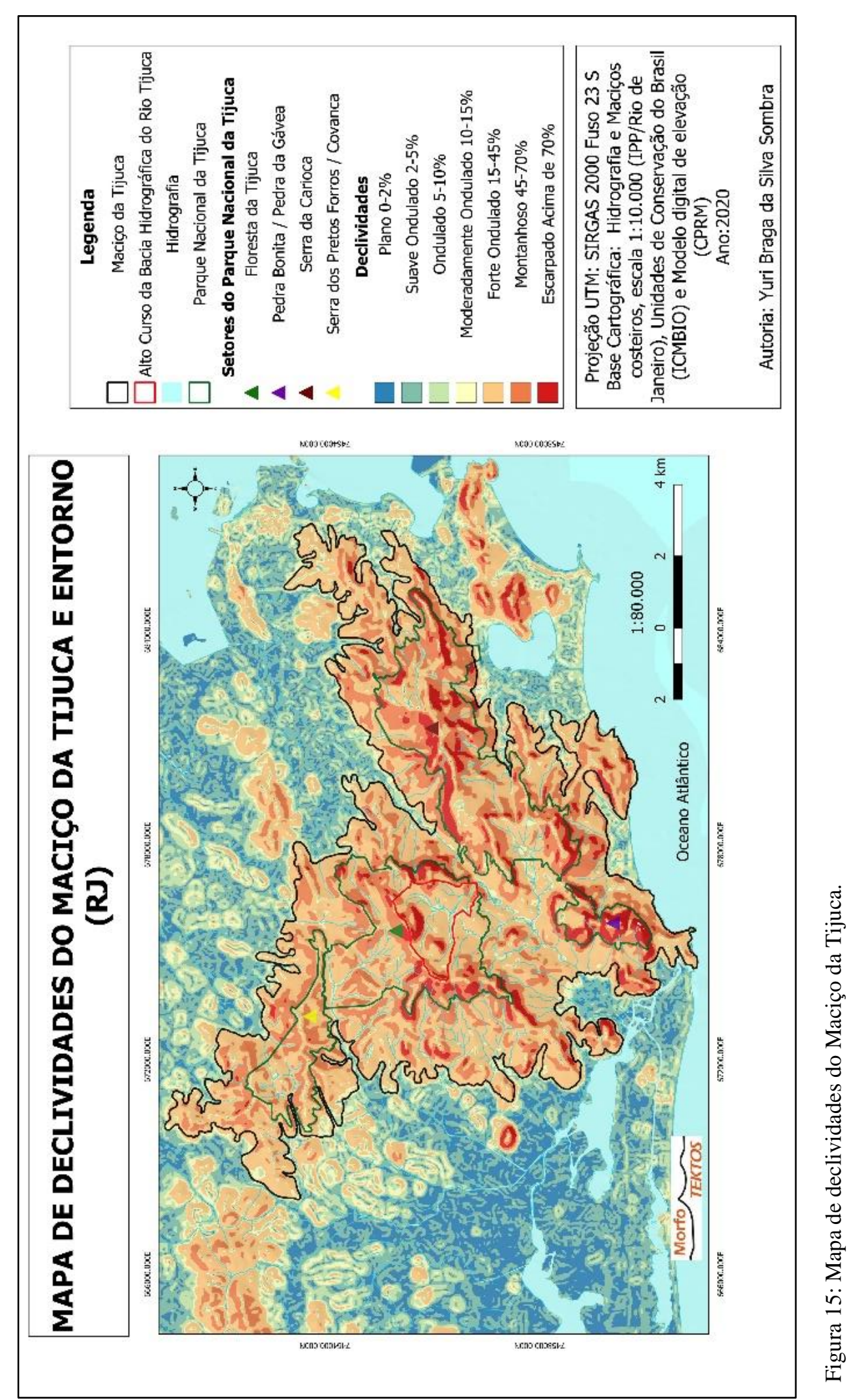


O mapa geomorfológico baseado no índice de posição topográfica-IPT (figura 16) indicou a presença das dez formas de relevo citadas em Weiss (2001), Silveira e Silveira $(2017 ; 2018)$. A primeira classe são os fundos de vale com forte incisão da drenagem, que apresentou $3,41 \%$ e possui maior ocorrência nas bordas do Maciço da Tijuca, em áreas de baixa declividade. Já os vales rasos e áreas de drenagem situadas no terço médio das vertentes se apresentam $8,42 \%$ do limite estudado. As cabeceiras de drenagens, com $0,40 \%$, estão situadas nos altos cursos das drenagens, com inclinações acentuadas. A quarta feição gerada, são as áreas situadas nos terços inferiores das vertentes ou vales abertos, são formas encontradas em baixos cursos de bacias hidrográficas e na base das vertentes, com 10,82\%.

Áreas planas constituem a quinta feição, e se mostram bem distribuída espacialmente, com ocorrências pontuais, e não possuindo grande tamanho, estando em $0,82 \%$ do maciço. Áreas situadas nas posições intermediárias das vertentes se localizam entre as baixadas e os patamares superiores, sendo as formas que apresentaram maior ocorrência, com 53,29\%, abrangendo as hipsometrias intermediárias (citadas anteriormente) e classes de declividades entre forte ondulado a escarpado. A sétima classe são as áreas situadas nas posições superiores das vertentes, nas quais ocorrem em $8,43 \%$, em pontos próximos aos picos e topos aplainados, como pedra da Gávea e Bonita, morro do Corcovado, o divisor de drenagem entre as bacias do rio Cachoeira e Maracanã e picos da Tijuca e Papagaio.

Os interflúvios secundários ou situados nas porções intermediárias das vertentes estão distribuídos na vertente sul do Maciço da Tijuca, abrangendo com baixas dimensões apenas os bairros da Zona Sul carioca, próximos aos setores Serra da Carioca e Pedra Bonita/Pedra da Gávea do PNT, com 0,09\%, sendo a menor porcentagem de área observada entre as classes mapeadas. A penúltima forma de relevo, é denominada topos rebaixados, interflúvios, cristas intermediárias ou morros em áreas planas, estando em todos os setores da área de estudo e em locais vinculados as altitudes intermediárias, com 7,38\%. Por fim, os interflúvios elevados ou na forma de cristas elevadas e topos elevados são encontrados nos pontos de maior altitude e na maioria dos divisores de drenagem, totalizando 6,84\% de presença na área de estudo. 


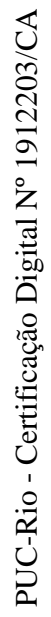

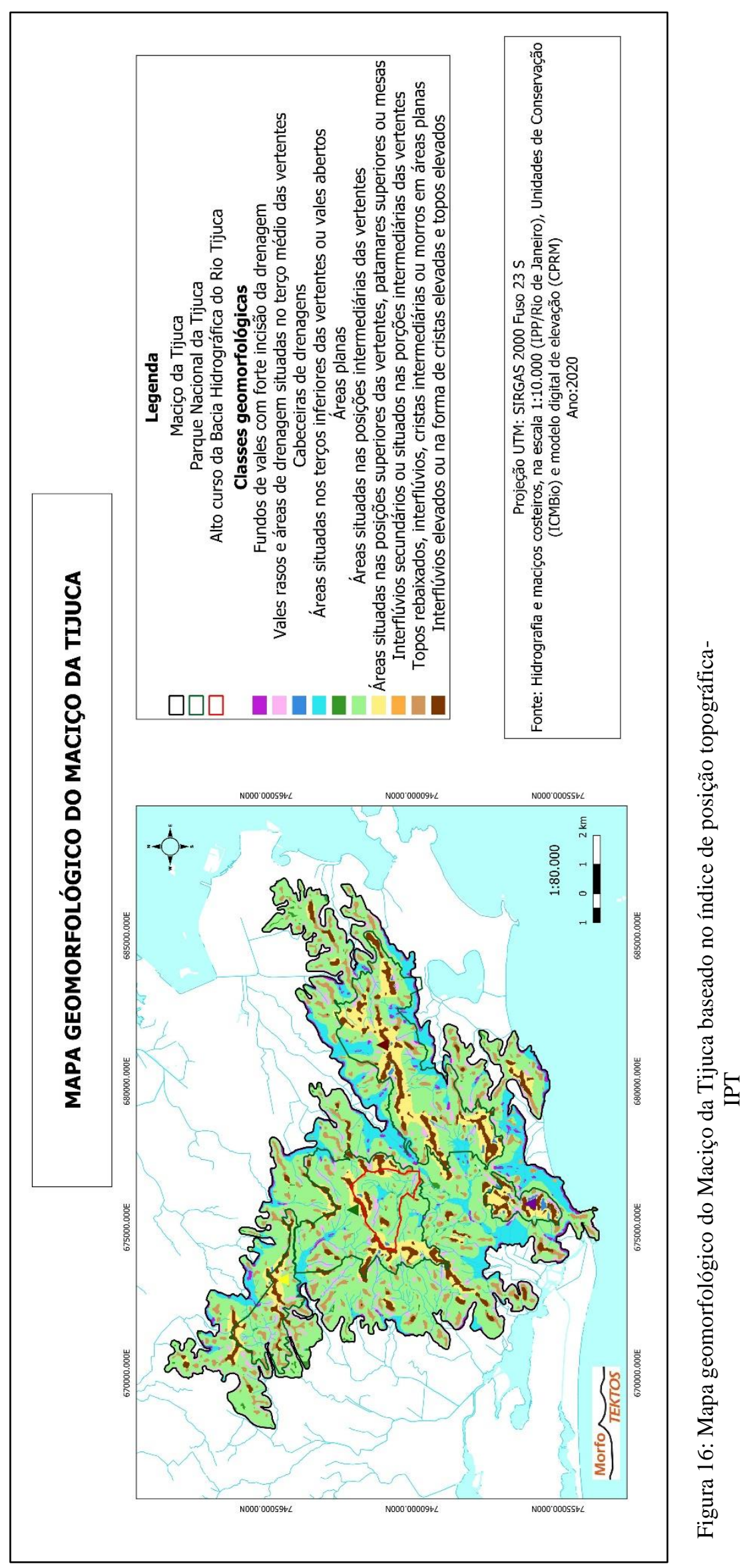


Tabela 11: Áreas em $\mathrm{km}^{2}$ e porcentagens das classes de relevo

\begin{tabular}{|c|c|c|}
\hline Classes & $\begin{array}{c}\text { Área } \\
\left(\mathbf{k m}^{\mathbf{2}}\right)\end{array}$ & $\begin{array}{c}\text { Porcentagem } \\
\mathbf{( \% )}\end{array}$ \\
\hline $\begin{array}{c}\text { Fundos de vale com forte incisão da } \\
\text { drenagem }\end{array}$ & 3,79 & 3,41 \\
\hline $\begin{array}{c}\text { Vales rasos e áreas de drenagem situadas } \\
\text { no terço médio das vertentes }\end{array}$ & 9,35 & 8,42 \\
\hline Cabeceiras de drenagens & 0,45 & 0,40 \\
\hline $\begin{array}{c}\text { Áreas situadas nos terços inferiores das } \\
\text { vertentes ou vales abertos }\end{array}$ & 12,02 & 10,82 \\
\hline Áreas planas & 0,92 & 0,82 \\
\hline $\begin{array}{c}\text { Áreas situadas nas posições intermediárias } \\
\text { das vertentes }\end{array}$ & 59,16 & 53,29 \\
\hline $\begin{array}{c}\text { Áreas situadas nas posições superiores das } \\
\text { vertentes }\end{array}$ & 9,36 & 8,43 \\
\hline $\begin{array}{c}\text { Interflúvios secundários ou situados nas } \\
\text { porções intermediárias das vertentes }\end{array}$ & 0,10 & 0,09 \\
\hline $\begin{array}{c}\text { Topos rebaixados, interflúvios, cristas } \\
\text { intermediárias ou morros em áreas planas }\end{array}$ & 8,20 & 7,38 \\
\hline $\begin{array}{c}\text { Interflúvios elevados ou na forma de } \\
\text { cristas elevadas e topos elevados }\end{array}$ & 7,60 & 6,84 \\
\hline
\end{tabular}

\subsection{4) Índice de Geodiversidade}

Para o mapa de índice de geodiversidade, foram estabelecidas cinco categorias de representação em ordem crescente: muito baixa, baixa, média, alta e muito alta. Haja visto a falta de escalas iguais, a presente etapa buscou obter uma estimativa generalizada para identificar os locais com maior ou menor geodiversidade e como esses resultados podem ser úteis a gestão do PNT. O primeiro índice (figura 17) apresentou maior presença das classes médio e baixo. A categoria médio, alto e muito alta ocorrem de maneira pontual, e em sua maior parte, nas bordas do Maciço da Tijuca. A categoria alta está presente em alguns locais muito visados por turistas e adeptos de práticas esportivas, como as áreas no entorno da Pedra da Gávea, Praia da Joatinga, Morros Dois Irmãos e Corcovado e Mirante Dona Marta. Também ocorrem em locais de ocupação densa e com impactos ambientais, como a favela da Muzema e entre os bairros de Cascadura e Praça Seca, na zona norte do Município do Rio de Janeiro. Áreas com geodiversidade muito baixa estão em partes dos setores Serra dos Pretos Forros/Covanca, Serra da Carioca e uma pequena parte próxima ao setor Pedra Bonita/Pedra da Gávea. Já a classe média está distribuída em sua maior parte nas bordas e em poucas porções no centro do maciço, como na Floresta da tijuca. 


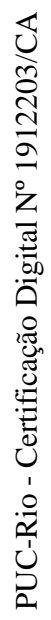

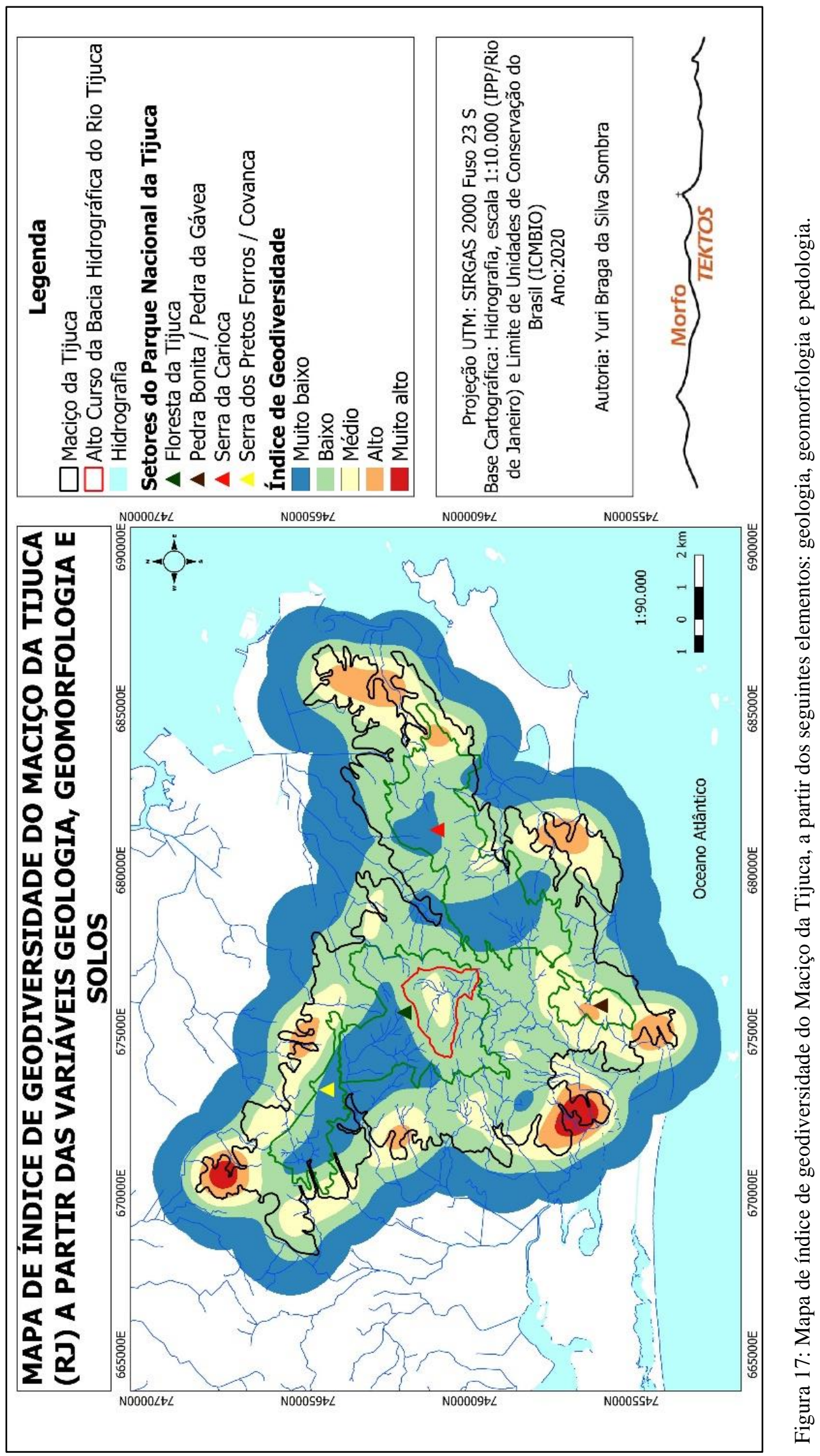


No segundo mapa de geodiversidade (figura 18), a hidrografia foi inserida na estimativa de Kernel, o que resultou informações muito diferentes do primeiro mapa. Certos locais que eram de alta geodiversidade, neste, estão com índice médio ou baixo, devido a inserção do elemento hidrografia. A classe muito alta ocorre próxima ao setor Floresta da Tijuca, na bacia do rio Cachoeira e dentro do setor Serra dos Pretos Forros/Covanca. Nas adjacências desta, está a categoria alto, assim como, em uma pequena porção na Serra da Carioca. Já o índice médio vincula-se as vertentes para a Zona Sul do rio de janeiro e que drenam para a bacia hidrográfica da Lagoa da Tijuca. Assim como no primeiro mapa, o baixo índice de geodiversidade predomina. A classe muito baixa está presente a noroeste do limite do maciço e no vale do rio Maracanã.

Cabe salientar que no segundo mapa as áreas em que ocorrem alta ou muito alta geodiversidade possuem influência pelas concentrações de drenagens, em detrimento dos demais elementos abióticos, visto a disparidade de escalas. Porém, se considera importante a presença da hidrografia na análise quantitativa de geodiversidade, pois está intimamente relacionada a geologia, geomorfologia e solos, assim como, é um dos atrativos mais importantes do Parque Nacional da Tijuca. 


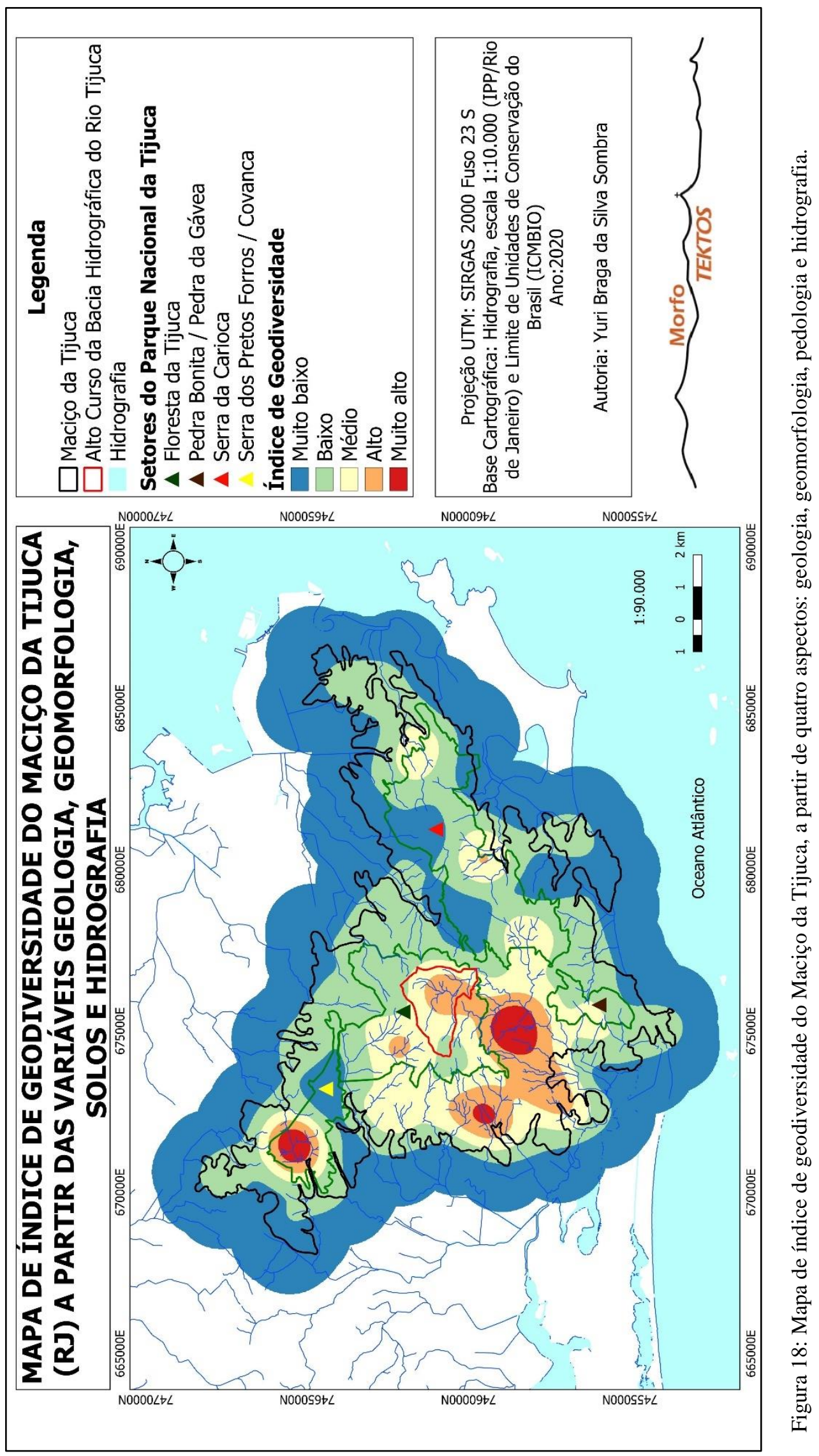




\section{2) Análise da Geodiversidade Para Aplicação ao Geoturismo do Alto Curso da Bacia do Rio Tijuca}

\subsection{1) Mapa Geomorfológico}

Na classificação do relevo para o alto curso da bacia de drenagem do rio Tijuca (1:10.000), o mapa geomorfológico apresenta maior detalhamento que o mapa anterior (figura 16). A classe das áreas situadas nas posições intermediárias das vertentes, continua apresentando maior ocorrência, apresentando 55,18\% da área mapeada. Há uma maior presença também da quarta classe, áreas situadas nos terços inferiores das vertentes ou de vales abertos, com 12,83\%. Assim como nos fundos de vale com forte incisão da drenagem, apresentando maior ocorrência, sobretudo, próximo à entrada da Floresta da Tijuca, tendo 2,51\% de ocorrência.

Os vales rasos e áreas de drenagem situadas nos terços médios das vertentes apresentam $7,02 \%$ e estão mais próximos a parte alta da bacia, com destaque para a área do sopé do Pico da Tijuca. Já a classe cabeceiras de drenagens ocorre de forma pontual próximo aos picos do Papagaio (Sub bacia do rio Archer) e Tijuca (Sub bacia do rio das Almas). De forma restrita, ocorrendo principalmente na parte sudoeste da área de estudo, estão as áreas planas com apenas $1.58 \%$. As áreas situadas nas posições superiores das vertentes estão próximas aos picos, em altas elevações e com declive acentuada, com 6,9\%. A classe interflúvios secundários ou situados nas porções intermediárias das vertentes assim como no mapa geomorfológico do Maciço da Tijuca, é a feição de menor representação, com apenas $0,24 \%$. Os topos rebaixados, interflúvios, cristas intermediárias ou morros em áreas planas estão principalmente nas bordas da bacia e no Morro do Archer, com 4,58\%. Por fim, os interflúvios elevados ou na forma de cristas elevadas e topos elevados marcam presença em $8,36 \%$ e possuem as altitudes mais elevadas. 


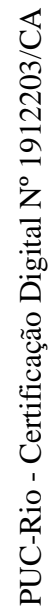
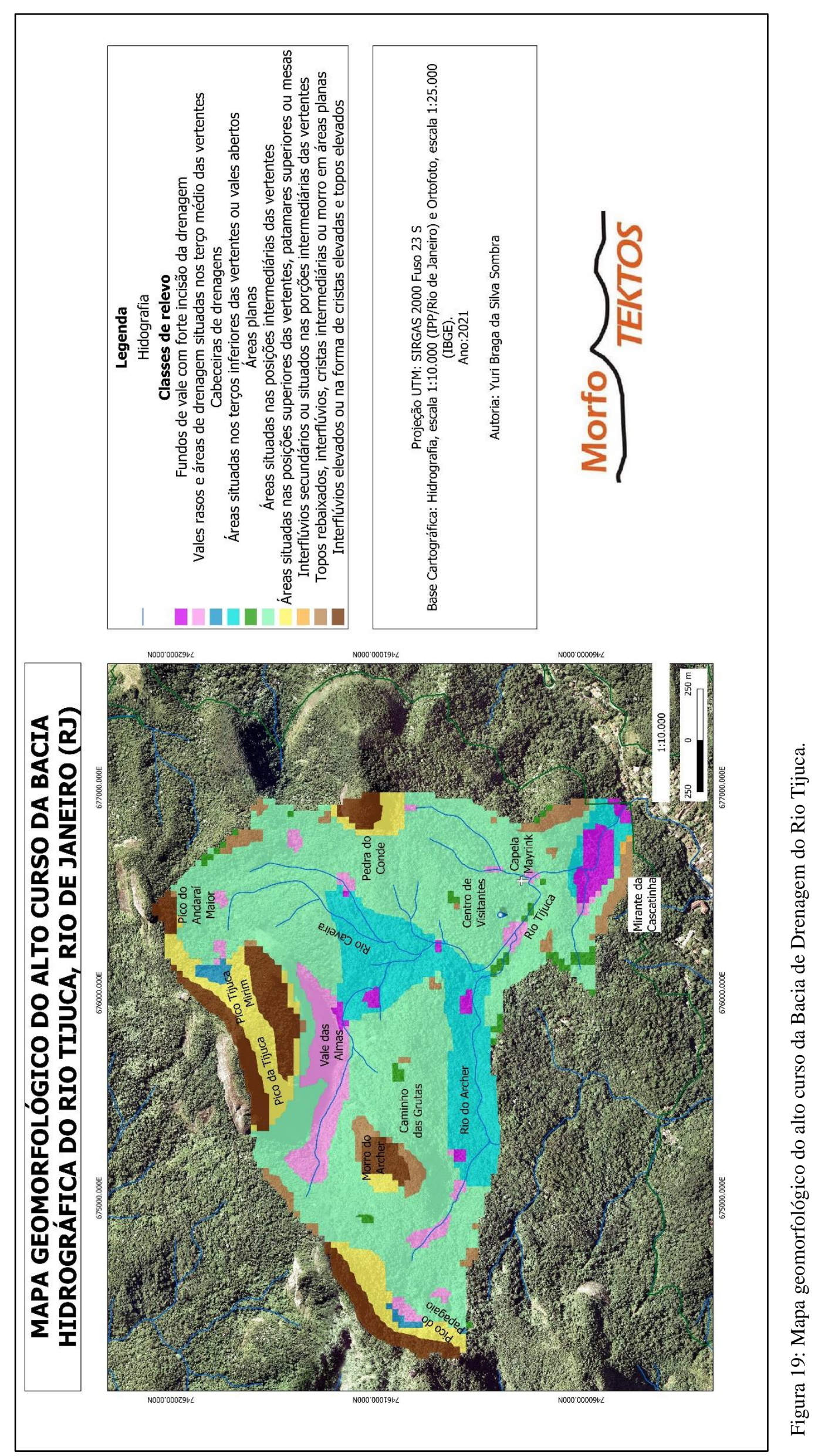
Tabela 12: Áreas em $\mathrm{m}^{2}$ e porcentagens das classes de relevo da Bacia do Rio Tijuca

\begin{tabular}{|c|c|c|}
\hline Classes & $\begin{array}{c}\text { Área } \\
\left(\mathrm{m}^{2}\right)\end{array}$ & Porcentagem (\%) \\
\hline $\begin{array}{c}\text { Fundos de vale com forte incisão da } \\
\text { drenagem }\end{array}$ & 92,7 & 2,51 \\
\hline $\begin{array}{c}\text { Vales rasos e áreas de drenagem situadas } \\
\text { no terço médio das vertentes }\end{array}$ & 259,2 & 7,02 \\
\hline Cabeceiras de drenagens & 27,9 & 0,75 \\
\hline $\begin{array}{c}\text { Áreas situadas nos terços inferiores das } \\
\text { vertentes ou vales abertos }\end{array}$ & 473,4 & 12,83 \\
\hline Áreas planas & 58,5 & 1,58 \\
\hline $\begin{array}{c}\text { Áreas situadas nas posições intermediárias } \\
\text { das vertentes }\end{array}$ & 2035,8 & 55,18 \\
\hline $\begin{array}{c}\text { Áreas situadas nas posições superiores das } \\
\text { vertentes }\end{array}$ & 254,7 & 6,90 \\
\hline $\begin{array}{c}\text { Interflúvios secundários ou situados nas } \\
\text { porções intermediárias das vertentes }\end{array}$ & 9 & 0,24 \\
\hline $\begin{array}{c}\text { Topos rebaixados, interflúvios, cristas } \\
\text { intermediárias ou morros em áreas planas }\end{array}$ & 169,2 & 4,58 \\
\hline $\begin{array}{c}\text { Interflúvios elevados ou na forma de } \\
\text { cristas elevadas e topos elevados }\end{array}$ & 308,7 & 8,36 \\
\hline \multicolumn{2}{|c|}{} \\
\hline
\end{tabular}

\subsection{2) Mapa Litológico}

No limite do alto curso da bacia de drenagem do rio Tijuca são encontrados rochas ígneas e metamórficas e depósitos sedimentares quaternários (figura 20). A litologia ígnea é representada pelo Granito Favela, que está vinculado a Suíte Nova Friburgo e, especificamente, encontrado no Pico do Papagaio. As metamórficas ortoderivadas são vinculadas ao complexo Rio Negro e a Suíte Rio de Janeiro, representadas respectivamente pelos Gnaisse Archer e Facoidal. Ocorre na parte nordeste, norte, noroeste e centro-leste da área de investigação. Já as paraderivadas, pertencem ao Grupo São Fidélis, onde são encontrados quartzito, kingizito e biotita gnaisse, tendo os dois primeiros ocorrem de forma restrita, a sul da delimitação mapeada. O contato entre o Complexo Rio Negro e Grupo São Fidélis ocorre no meio do alto curso bacia do rio Tijuca, em direção nordeste, na qual é a principal direção encontrada na Faixa Móvel Ribeira. O Gnaisse Facoidal possui contato na Pedra do Conde com o quartzito e na parte centro-oeste da bacia possui morfologia de divisor rebaixado entre as bacias dos rios da Solidão e do Archer, muito intemperizado, possuindo contato com quartzito e gnaisse Archer. 


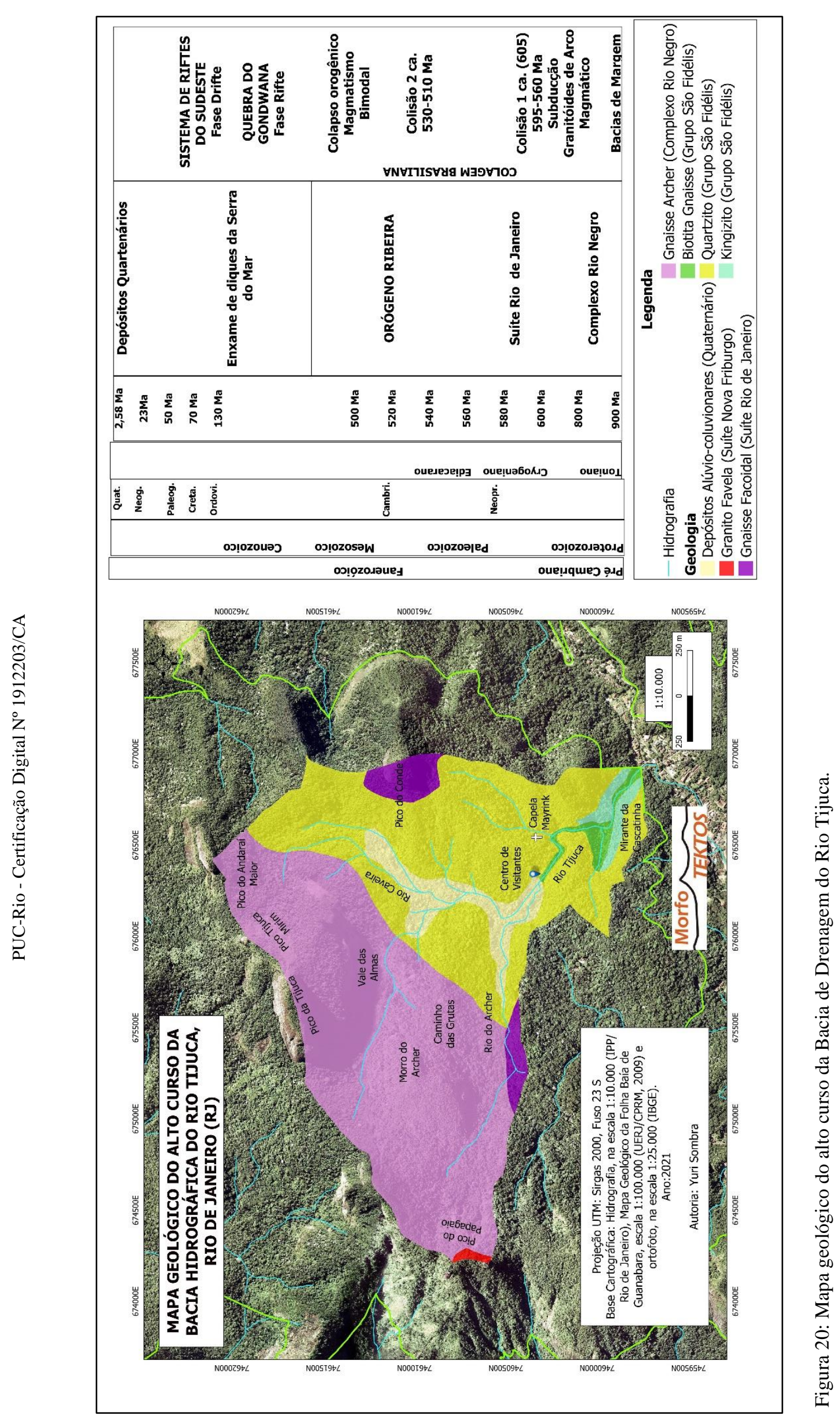


As maiores porcentagens referentes as classes de litologia mapeadas (tabela 13) pertencem ao ortognaisse do Complexo Rio Negro e quartzito do Grupo São Fidélis, respectivamente, 50, 9\% e 36,27\%. O contato central na bacia se dá por estas rochas, com as ortoderivadas a norte e as paraderivadas a sul. Há uma grande dificuldade em achar o contato exato, devido ao intenso processo de erosão ao longo do tempo. Em especial, o quartzito possui poucos afloramentos, tendo grande parte marcado pela ação intempérica (figura 21). Também há ocorrência de blocos deste tipo litológico nos topos de morros, a exemplo, do Morros do Almeida, do Visconde, da Bandeira, Alto do Visconde, Alto do Mayrink e do Mesquita. A maior presença de blocos ortoderivados se dá na base do Morro do Archer, onde há grande depósito de tálus e ocorrências de grutas.

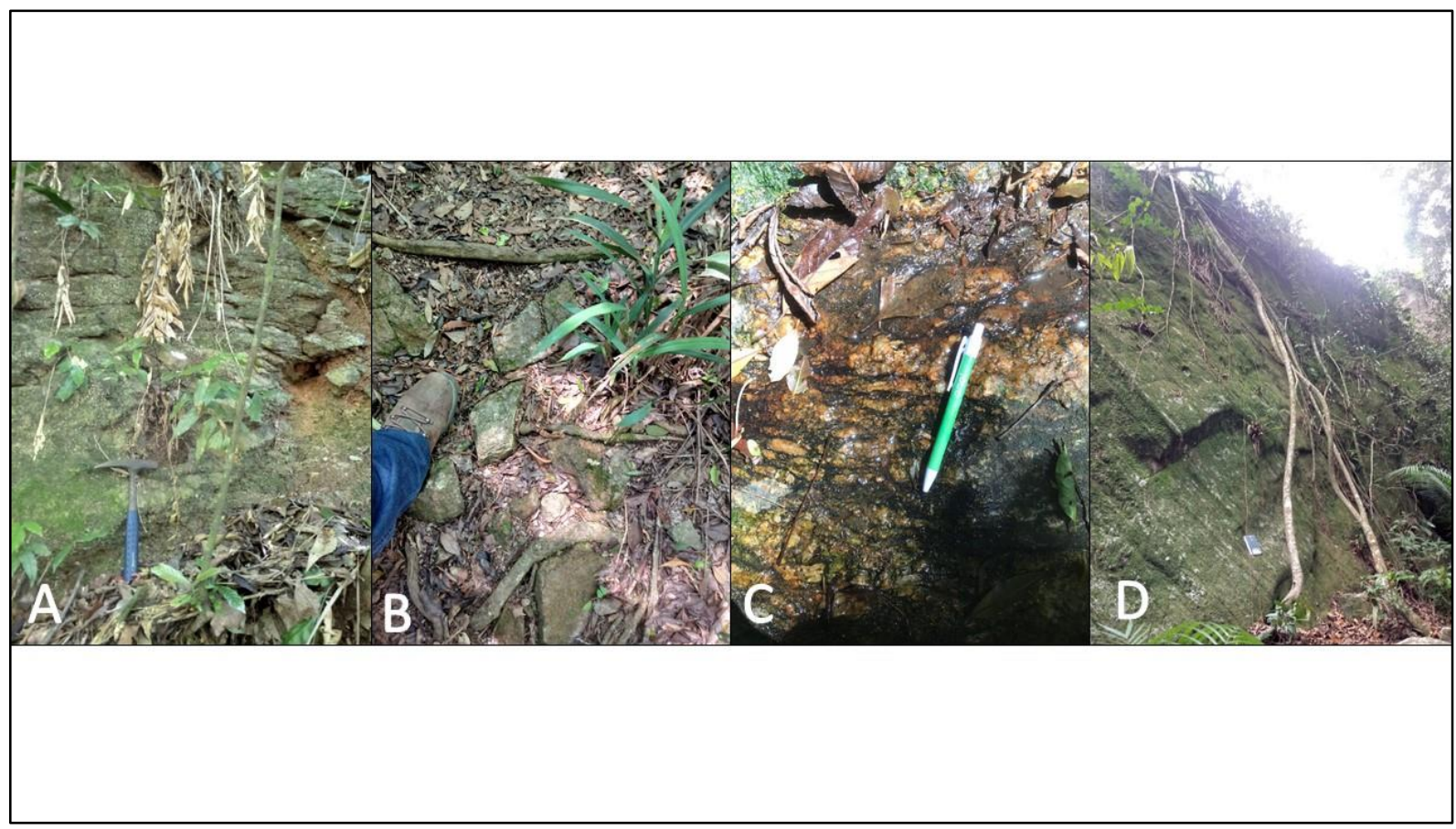

Figura 21: Quartzito e Gnaisse Archer. A-Afloramento de quartzito com indicação de dobramento. B- Blocos de quartzito na trilha para o Morro da Bandeira. C- Ortognaisse no leito do rio do Archer; D- Bloco de gnaisse no Caminho das Grutas.

As porcentagens medianas são dos depósitos alúvio-coluvionares $(5,51 \%)$ e gnaisse facoidal $(3,44 \%)$. Os depósitos mapeados estão no centro do limite estudado e representam o encontro entre os vales do rio do Archer e rio das Almas. O rio Tijuca se forma na parte final do vale das Almas com a junção dos rios das Almas e rio Caveira. Próximo ao Centro de Visitantes do PNT, o rio do Archer deságua no rio Tijuca. Obviamente há outros depósitos coluviais e aluviais na bacia, porém em menor dimensão do que o mapeado. O presente material sedimentar se destaca na paisagem, se caracterizando como vale suspenso, sobretudo na junção entre as 
planícies de inundação dos rios do Archer e Tijuca, estando na margem esquerda do primeiro e na margem direita do segundo (figura 22). O gnaisse facoidal, como mencionado anteriormente, se encontra nas bordas leste e oeste da área de estudo, e também em grande parte do Maciço da Tijuca e da Cidade do Rio de Janeiro.

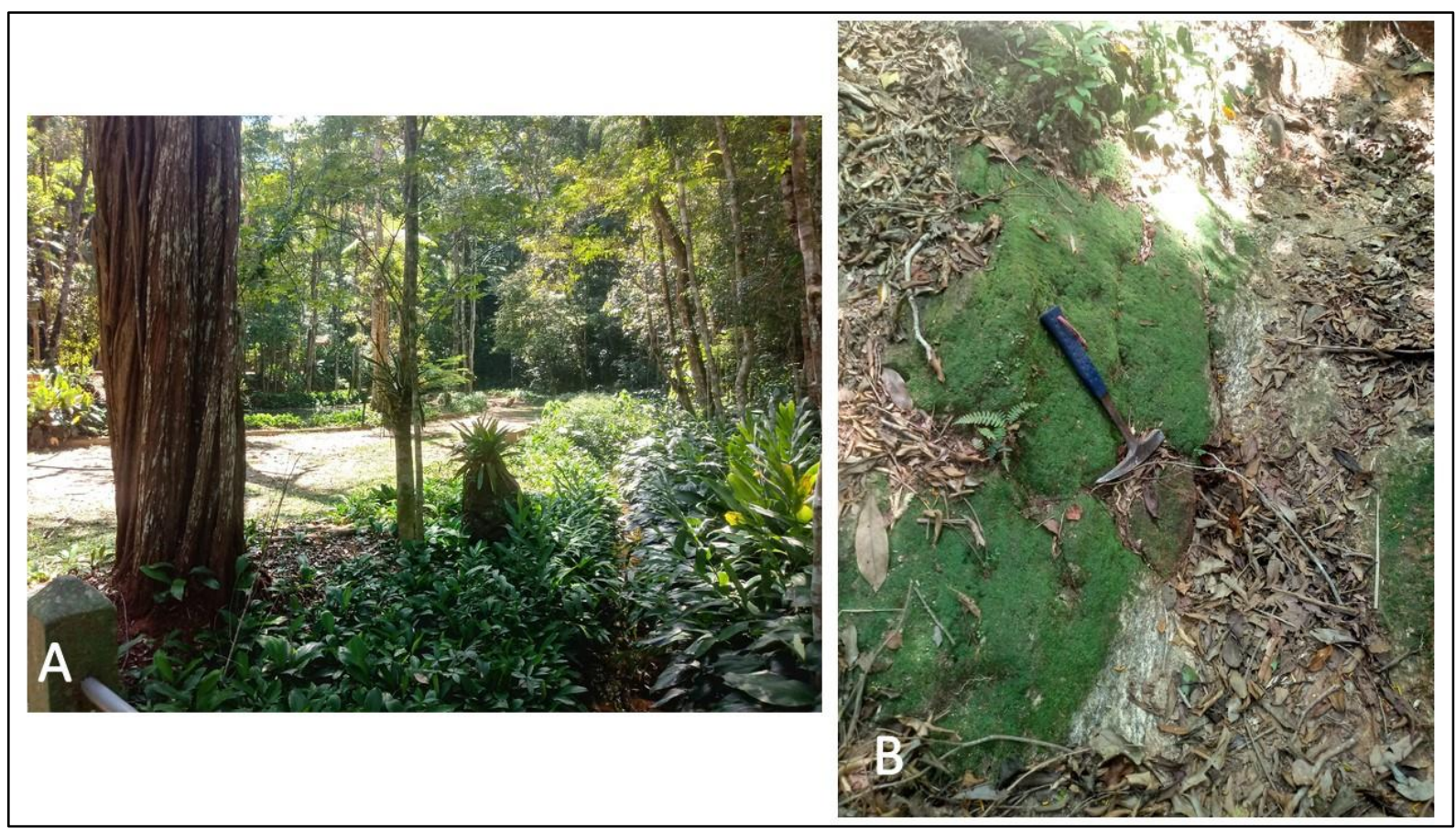

Figura 22: Planície de inundação e Gnaisse Facoidal. A-Recanto dos Pintores, com presença de depósitos aluviais; B- Afloramento de Gnaisse Facoidal na Trilha da Barreira, que liga o Restaurante dos Esquilos com a Estrada Major Archer.

O granito Favela, biotita gnaisse e kingizito apresentam as menores ocorrências (figura 23). O primeiro está restrito no limite nordeste da bacia e possui $0,25 \%$. O biotita gnaisse possui $1,48 \%$ e se destaca principalmente na parte inicial da Floresta da Tijuca, possuindo importante afloramento na Cascatinha de Taunay. Possui algumas variações em sua composição, com ocorrência também de silimanita e granada. Já o kingizito é caracterizado por ser muito intemperizado. Está em 0,86\% da área mapeada e se conecta as demais rochas do Grupo São Fidélis por forte dobramento. 


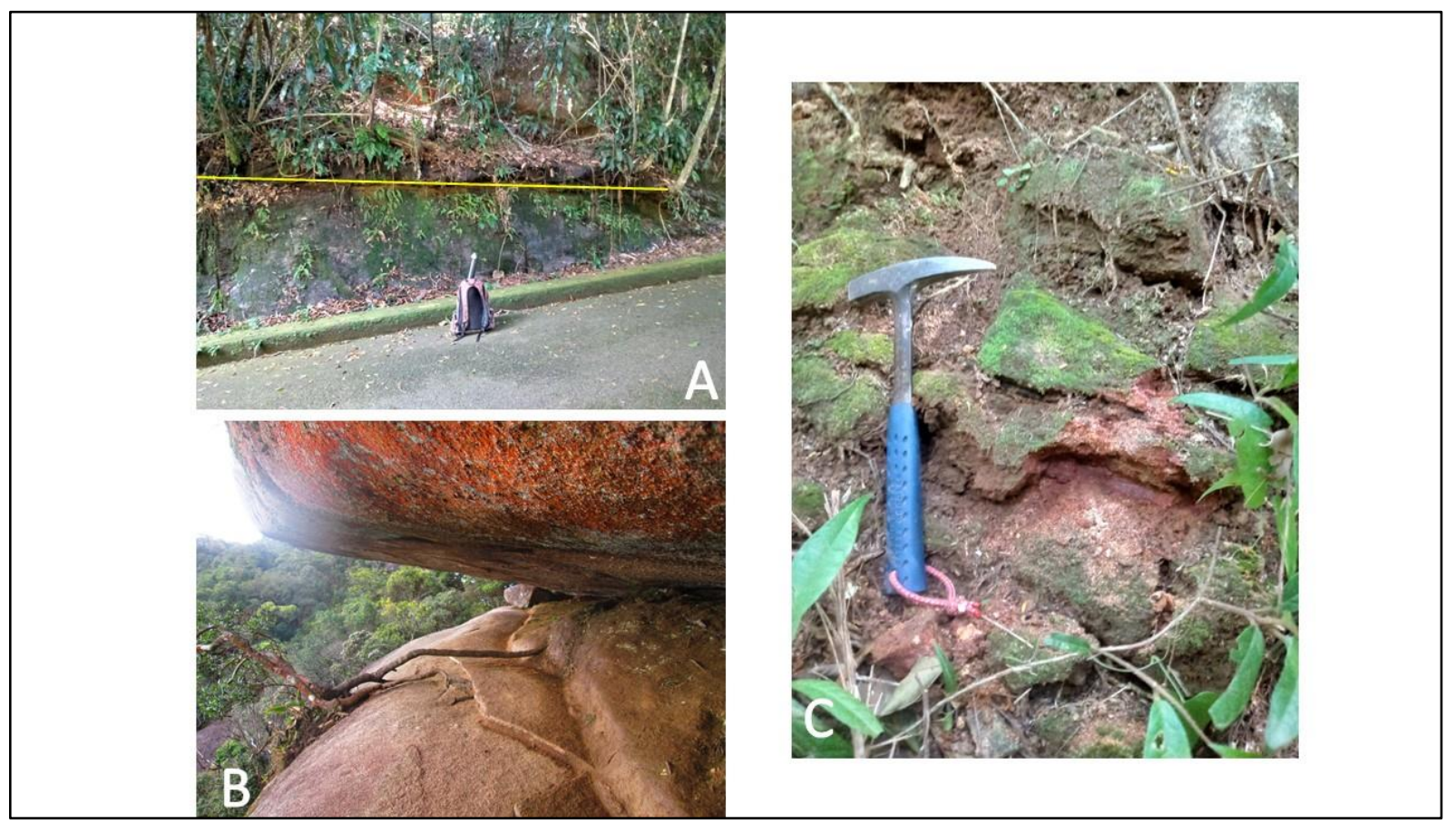

Figura 23: Biotita Gnaisse, Granito Favela e Kinzigito. A- Linha amarela representando o contato entre biotita gnaisse (abaixo) e quartzito (acima).

Tabela 13: Área em hectares e porcentagem das classes de geologia

\begin{tabular}{|c|c|c|}
\hline Litologia & Área $\mathbf{( H a )}$ & Porcentagem $\mathbf{( \% )}$ \\
\hline Biotita Gnaisse & 5,47 & 1,48 \\
\hline $\begin{array}{c}\text { Depósitos Alúvio- } \\
\text { coluvionares }\end{array}$ & 20,28 & 5,51 \\
\hline Gnaisse Archer & 187,67 & 50,9 \\
\hline Gnaisse Facoidal & 12,69 & 3,44 \\
\hline Granito Favela & 0,937 & 0,25 \\
\hline Kingizito & 5,55 & 0,86 \\
\hline Quartzito & 133,50 & 36,27 \\
\hline
\end{tabular}

\section{3) Sítios de Geodiversidade}

Nesta fase, foram contabilizados 28 sítios de geodiversidade (figura 24). Este fato demonstra que a bacia do rio Tijuca possui um potencial muito grande e que necessita de maior detalhamento e divulgação da sua diversidade abiótica. Para maior facilitação de entendimento, foram estabelecidos três setores da bacia: Alto, Médio e Baixo, escalonados desde os picos mais altos (setor alto), o vale suspenso da bacia do Rio Tijuca (setor médio) e os vales entalhados em direção à saída do Parque (setor baixo). Os sítios identificados serão listados então por setores a seguir: 


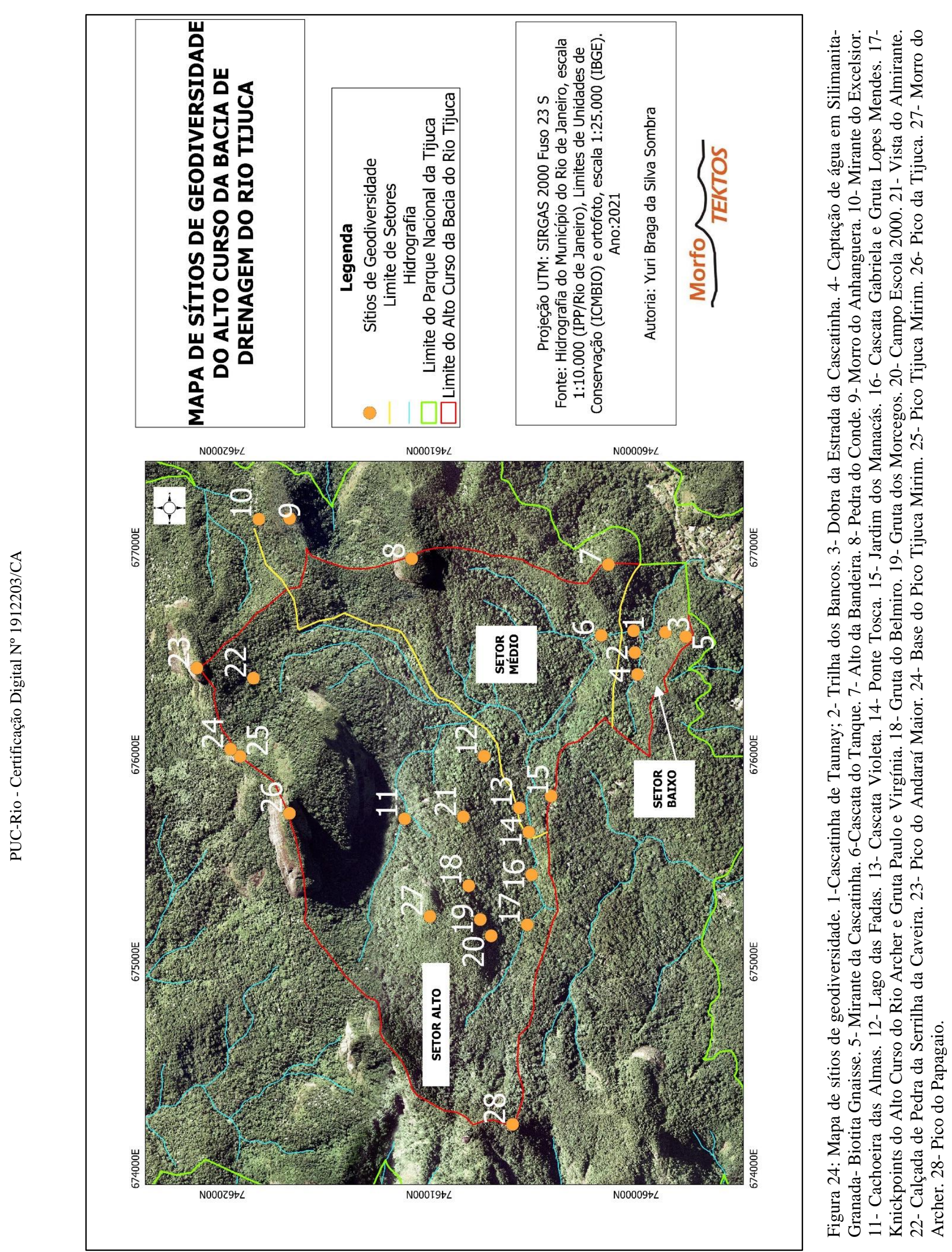




\subsection{1) Setor Baixo}

\section{Cascatinha de Taunay}

Este sítio é uma das grandes atrações turísticas do Parque Nacional da Tijuca. Possui um apelo estético muito forte e fornece informações didáticas sobre geomorfologia, tectônica e petrologia. É caracterizado pela ocorrência de Biotita Gnaisse com presença de veios graníticos, bandamentos e fraturas que exercem controle sobre a drenagem. Sobre a perspectiva geomorfológica se configura como um nível de base local ou knickpoint (na língua inglesa), com considerável desnivelamento altimétrico (figura 25).

O nome se origina do pintor Francês Nicolas-Antonie Taunay. Segundo Priedols et al. (2010) o artista chegou ao Brasil com a Missão Artística Francesa em 1816 e fixou residência ao lado da Cascatinha, tornando-se grande divulgador daquele local. Outro destaque se dá pela presença da Ponte Escragnole sobre o rio Tijuca. 


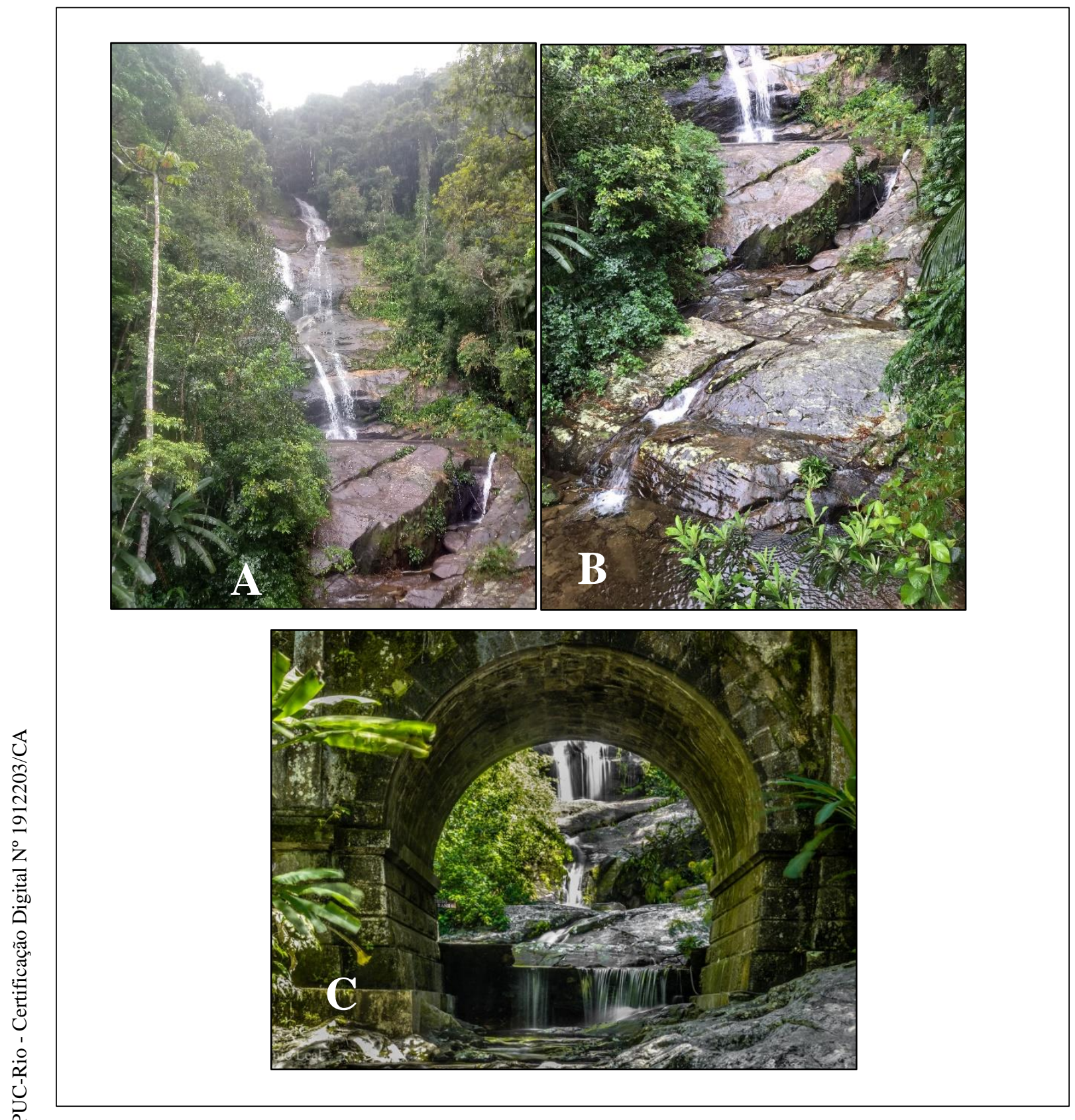

Figura 25: Cascatinha de Taunay. A- Visão geral da cascata; B- Fraturas. Fonte: Fernando Gomes Oliveira; C- Parte inferior da ponte Job de Alcântara com a cascata ao fundo. Fonte: 〈https://prond.com.br/explorar/rj/rio-de-janeiro/cascatinha-taunay-floresta-da-tijuca〉, acesso em $14 / 04 / 21$.

\section{Trilha dos Bancos}

O presente sítio está localizado na Trilha dos Bancos, logo após a Cascatinha de Taunay (figura 26). O nome se deve a presença de bancos para descanso ao longo do caminho, que segundo Siqueira et al. (2013), são revestidos por azulejos de Sèvres, datados do século XIX. Este ponto apresenta caráter didático, pois do início ao fim da trilha é possível observar afloramentos de Biotita Gnaisse, o mesmo gnaisse do ponto anterior, onde ocorrem bandamentos e fraturas e é possível 
observar o escoamento subterrâneo que escorre entre as fraturas e, que em função do corte feito pela trilha, aflora na forma de gotejamentos constantes.

Há placas na trilha que mostram a dinâmica hidrológica do ambiente florestal, porém, as placas podem ser incrementadas demonstrando uma maior relação com a geodiversidade.

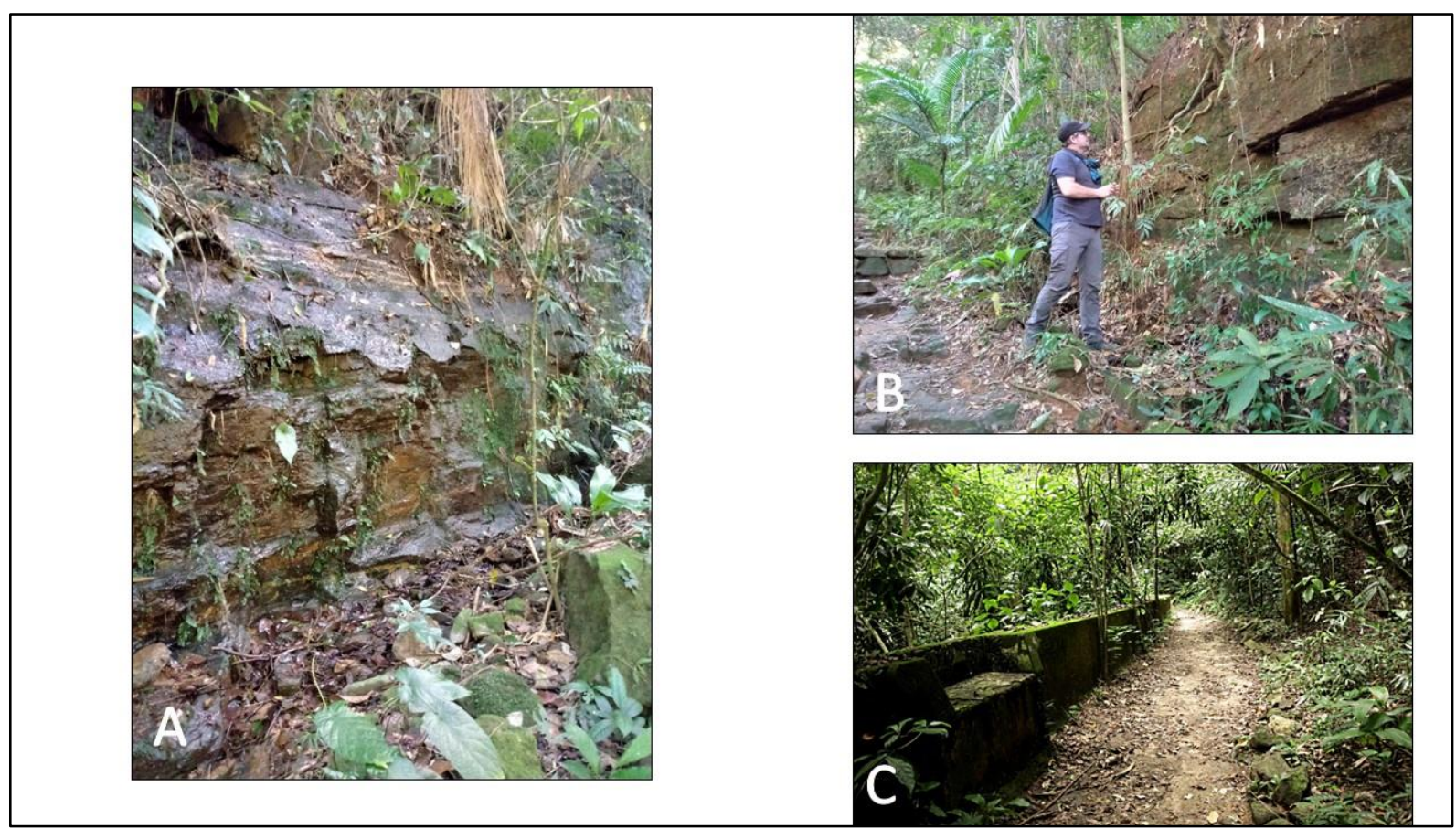

Figura 26: Trilha dos Bancos. A- Afloramento com escoamento hídrico e serrapilheira em sua base; B- Afloramento com fratura no início da trilha; C- Parte da trilha após primeira curva, com destaque ao banco (O ECO, 2013). Disponível em https://www.oeco.org.br/noticias/27706-uerj-lanca-guiasobre-trilhas-do-parque-nacional-da-tijuca/.

\section{Captação de água em Biotita Gnaisse}

Acima da área citada anteriormente, ocorre afloramentos do mesmo biotita gnaisse com veios, escoamento hídrico e captação de água para os usuários do Parque utilizarem (figura 27). Demonstra ser uma área de interesse múltiplo, pois pode ser útil ao turismo como para pesquisas científicas.

Os veios graníticos se destacam, tornando a área um laboratório a céu aberto, tanto de petrologia como de hidrologia. A direita da captação, há o contato entre o Quartzito e a Biotita Gnaisse, sendo a primeira rocha citada vinculada a antigos ambientes arenosos e a segunda, a uma sedimentação lamosa pretérita. Esta verificação, contribui para as discussões de geoconservação e evolução geológica na visitação ao presente sítio. 


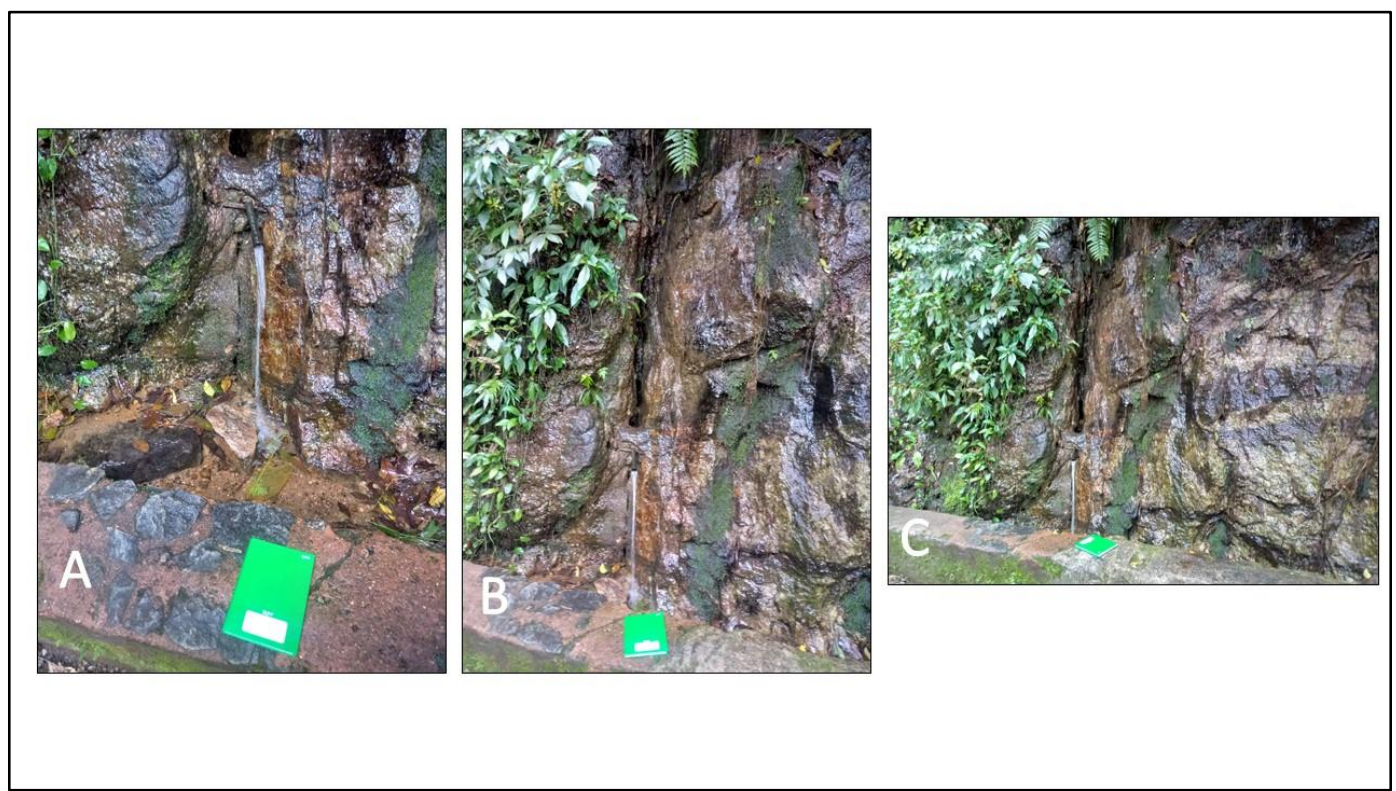

Figura 27: Captação de água em biotita gnaisse, que chega a ter uma canalização do fluxo para utilização dos usuários.

\section{Mirante da Cascatinha}

Uma das grandes atrações da área de estudo, o Mirante da Cascatinha fornece um excelente panorama, na qual é possível observar alguns picos da bacia e serras fora do limite da área de estudo. Está inserido no Morro do Visconde, que está a oeste do portão de entrada da Floresta da Tijuca (figura 28).

É possível visualizar e realizar discussões sobre o papel dos níveis de base locais (knickpoints) sobre a evolução geomorfológica, resistência litológica e erosão diferencial. O mirante está localizado sobre afloramentos de quartzito, onde há pouco desenvolvimento de solo. Há estrutura de madeira instalada para apreciação da paisagem, no formato deck e placa explicativa com mapa, foto e descrição, porém sem menções à geodiversidade. 


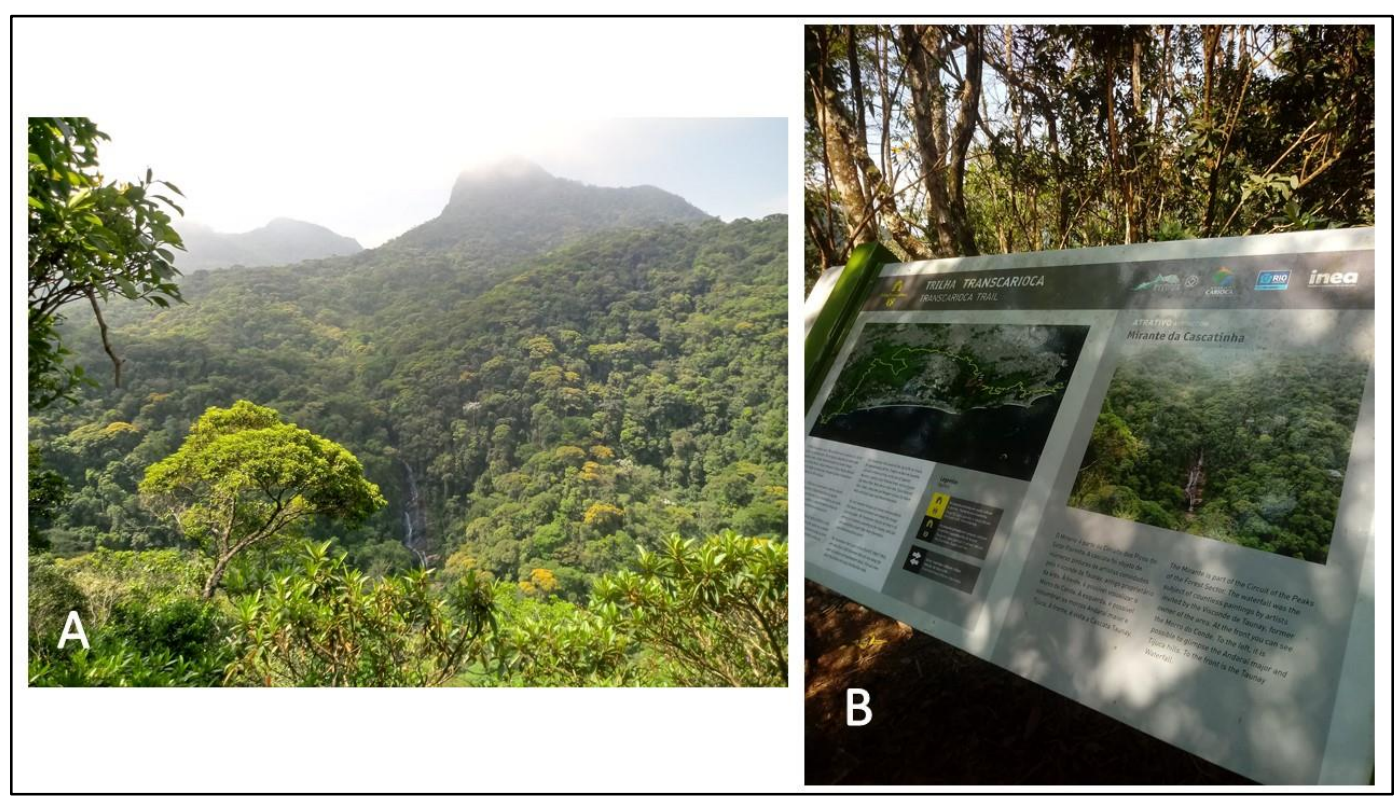

Figura 28: Mirante da Cascatinha. A:Visão da cascatinha de Taunay e, picos e vale suspensos; BPlaca próximo ao Mirante.

\section{Dobra de Quartzito da Estrada da Cascatinha}

A presente estrutura se destaca em uma curva na Estrada da Cascatinha, paralela à Trilha dos Bancos. A litologia local é caracterizada por quartzito e suas estruturas de foliação apresentam-se dobradas, revelando o esforço tectônico em seu processo de formação. É um afloramento importante para divulgação científica pois facilita a compreensão do que representa uma dobra e como está organizada a litoestratigrafia na Floresta da Tijuca, na qual os quartzitos estão no topo do Grupo São Fidélis.

O acesso se dá pelo acostamento da estrada, porém é necessário ter uma estrutura turística adequada para a observação e análise da área, de preferência com uma placa explicativa e desenhos esquemáticos para uma compreensão didática do fenômeno. 


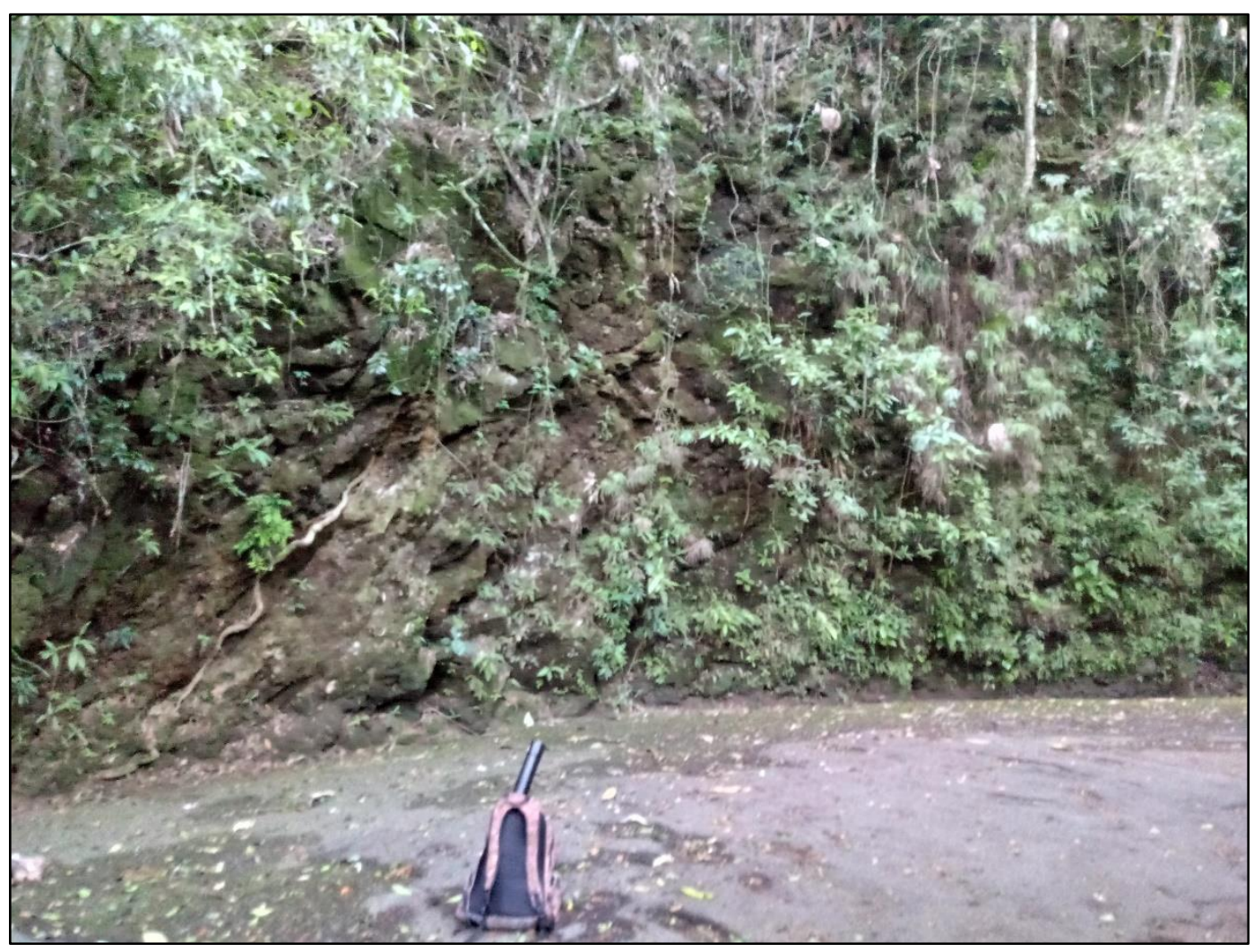

Figura 29: Dobra da Estrada da Cascatinha

\subsection{2) Setor Médio}

\section{Cascata do Tanque}

A cascata do Tanque se localiza próximo a capela Mayrink e está a montante da cascatinha de Taunay (figura 30). Apresenta sequência de níveis de base locais (knickpoints) em afloramentos de Biotita Gnaisses e Kinzigito no leito fluvial rochoso. A jusante deste ponto e antes da própria queda da Cascatinha Taunay ocorrem processos de sedimentação, devido ao papel dos níveis de base na quebra da energia de transporte da carga sedimentar fluvial. Consiste em um ponto com grande potencial geoturístico com ênfase nos processos fluviais. O uso recreativo das cachoeiras é proibido nesse ponto por questões de segurança, mas a área possui grande beleza cênica e opções de recreação próximas, como playground com mesas e churrasqueira. Seguindo as propostas de Gray (2013), podem ser observados nesse ponto, os potenciais serviços que se vinculam a este local associados a suporte turístico, conteúdos culturais e conhecimento científico. 


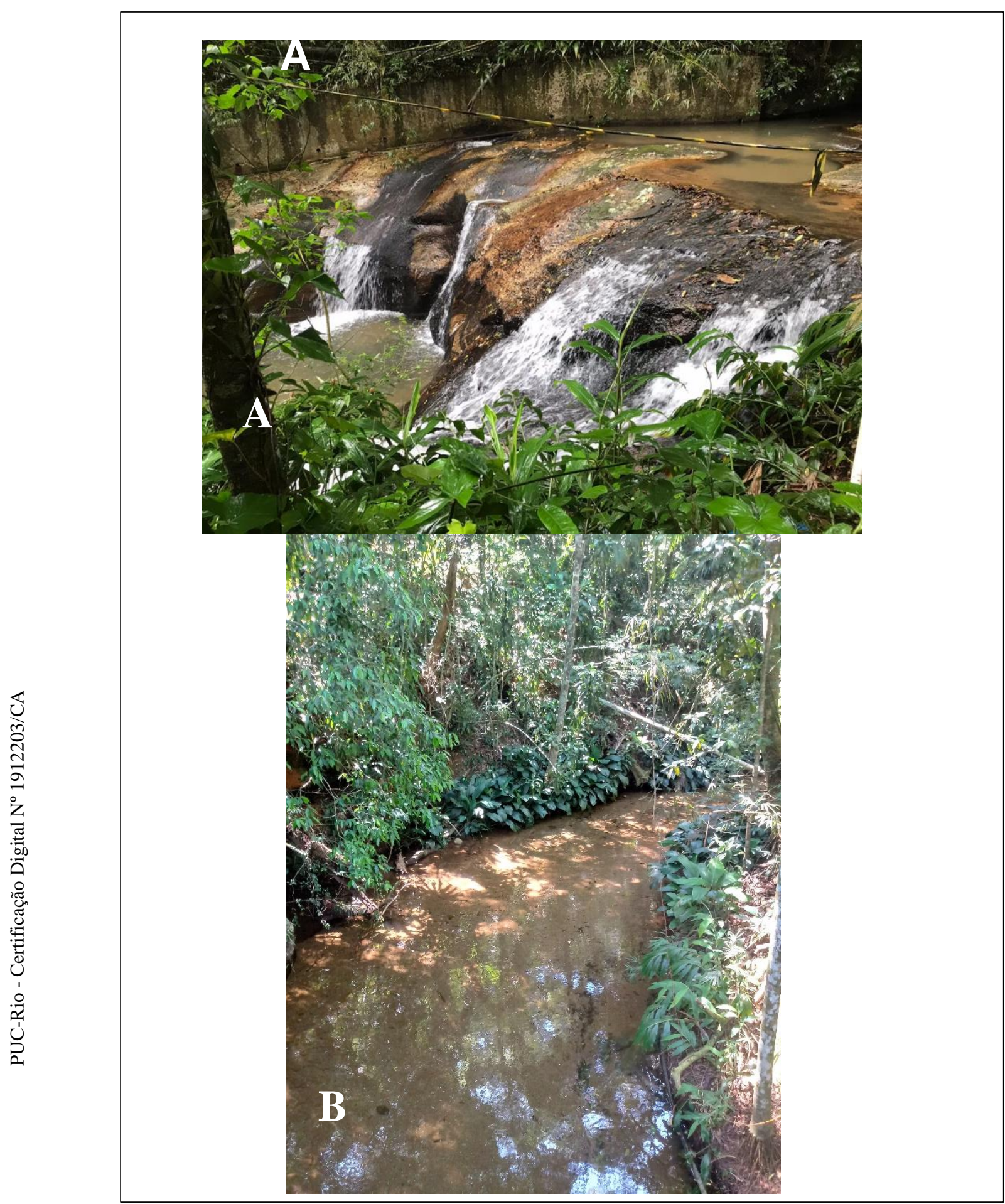

Figura 30: Sítio de geodiversidade Cascata do Tanque. A- Knickpoint que ressalta o leito do rio; BMeandro localizado ajusante ao knickpoint, no qual se configura opostamente a imagem A, onde o rio apresenta sedimentação.

\section{Mirante do Excelsior}

No extremo leste, da bacia de drenagem do rio Tijuca, em seu divisor com o rio Excelsior e no sopé do Morro do Anhaguera, está instalado o Mirante do Excelsior (figura 31). Com vista exuberante da zona norte da cidade e do centro do Rio de Janeiro, Baía de Guanabara e da cidade de Niterói, o mirante foi fundado no 
Século XIX, pelo Barão D’Escragnole e inspirada no poema Excelsior do escritor estadunidense Henry Wadsworth Longfellow. O acesso mais fácil se dá pela estrada homônima, mas também pode-se chegar pelo Caminho da Pedra do CondeAnhaguera. Estas características demonstram o valor cultural da área.

Em seu aspecto geológico, novamente o substrato rochoso é composto pelos quartzitos do Grupo São Fidélis. Próximo à entrada do mirante apresentam-se afloramentos do quartzito que podem constituir pontos de interesse geológico que revelam a transformação metamórfica dos antigos depósitos arenosos situados na bacia sedimentar back arc do Grupo São Fidélis.

Em relação à infraestrutura, há aspectos que precisam ser melhorados, como reforma da estrutura de concreto do mirante, que apresenta rachadura e placas indicativas e informativas danificadas.

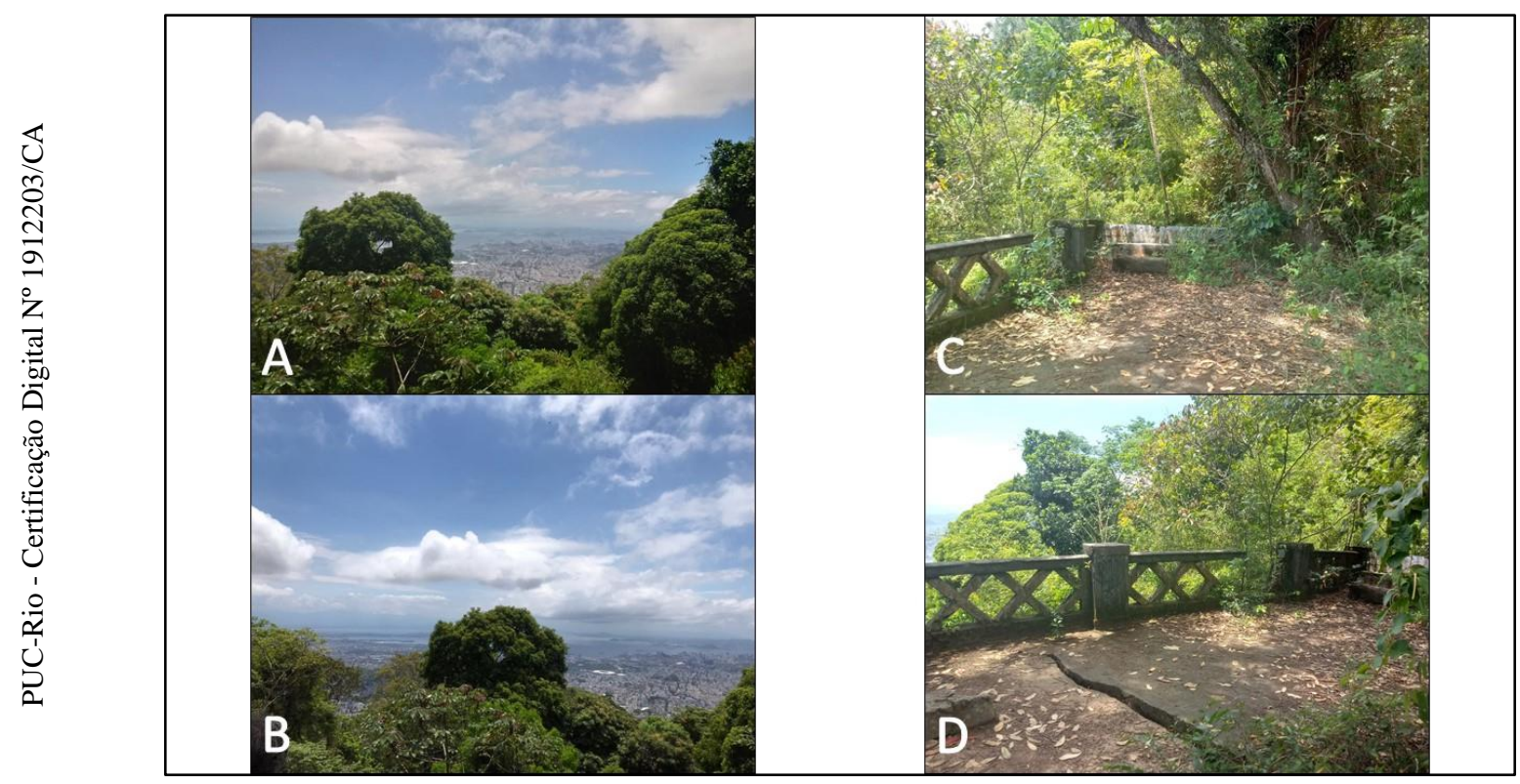

Figura 31- Mirante do Excelsior. A-Vista para Niterói; B-Vista para a Baía de Guanabara e seu fundo; C- Mureta e banco sem manutenção; D- Rachadura em frente a mureta de apoio para observação.

\section{Cascata Violeta (Efêmera)}

Após o vale suspenso na qual se encontra o centro de visitantes da Floresta da Tijuca e a sede administrativa do Parque, conhecida como Barracão há o Caminho Pedro Augusto, apresentando importantes aspectos geológicos, biológicos, históricos e bancos para descanso. Dentre estes pontos está a Cascata Violeta, caracterizada por ser uma drenagem efêmera ou intermitente, ou seja, que possui água apenas nas estações chuvosas (figura 32). 
A drenagem encaixa-se sobre uma estrutura de dobramento do quartzito, altamente fraturada. A drenagem com canal de drenagem bem definido corta o caminho, vertente abaixo. O dobramento indica uma estrutura anticlinal, com alto grau de fraturamento e se torna um excelente ponto de interesse geológico capaz de exemplificar didaticamente processos tectônicos e esforços crustais para a formação de dobras e fraturas, contribuindo assim para estudos científicos, roteiros geoturísticos e atividades educacionais.

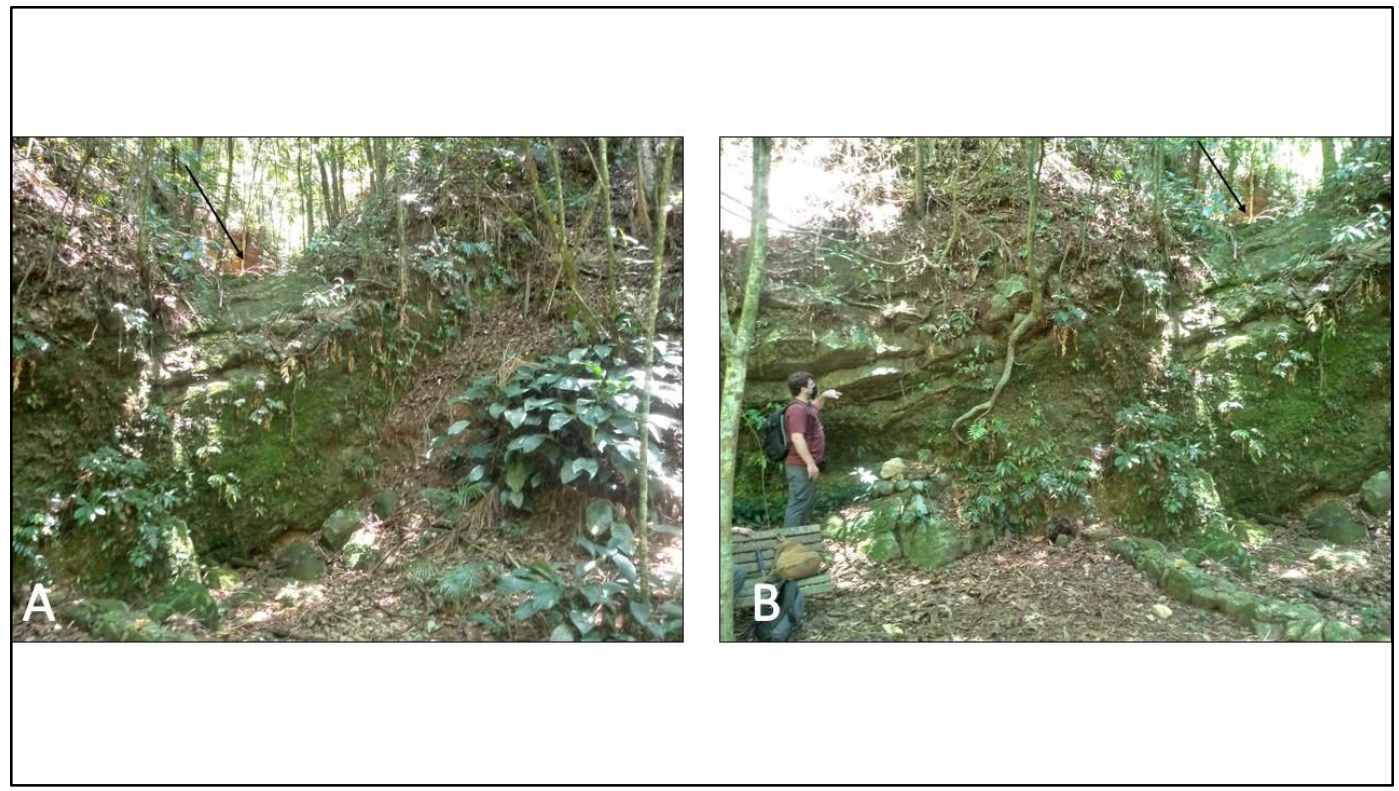

Figura 32: Cascata Violeta. A- Seta indicando canal de drenagem efêmero e indicação de dobramento sobre quartzito; B- Afloramento de quartzito com indicação de fraturas e seta indicando canal de drenagem.

\section{Ponte Tosca}

O presente sítio também está localizado no Caminho Pedro Augusto. Se caracteriza por ser uma pequena ponte sobre o rio do Archer, sustentada por blocos de rocha (matacões) em suas pontas. De acordo com Maia (1967) é uma reminiscência da administração do Barão de Escragnolle, tendo Auguste Glaziou, Paisagista Francês, assistido a obra. É um sítio de geodiversidade ex situ (figura 33), no qual demonstra valor histórico e cultural.

O local apresenta depósitos de tálus no rio e na vertente, provenientes de antigas avalanches detríticas que permitem o entendimento do trabalho de entalhamento fluvial, recuo de vertentes e abertura de vale, pois está na transição da encosta para a planície aluvial onde está o Recanto dos Pintores, Centro de Visitantes e o Barracão. 


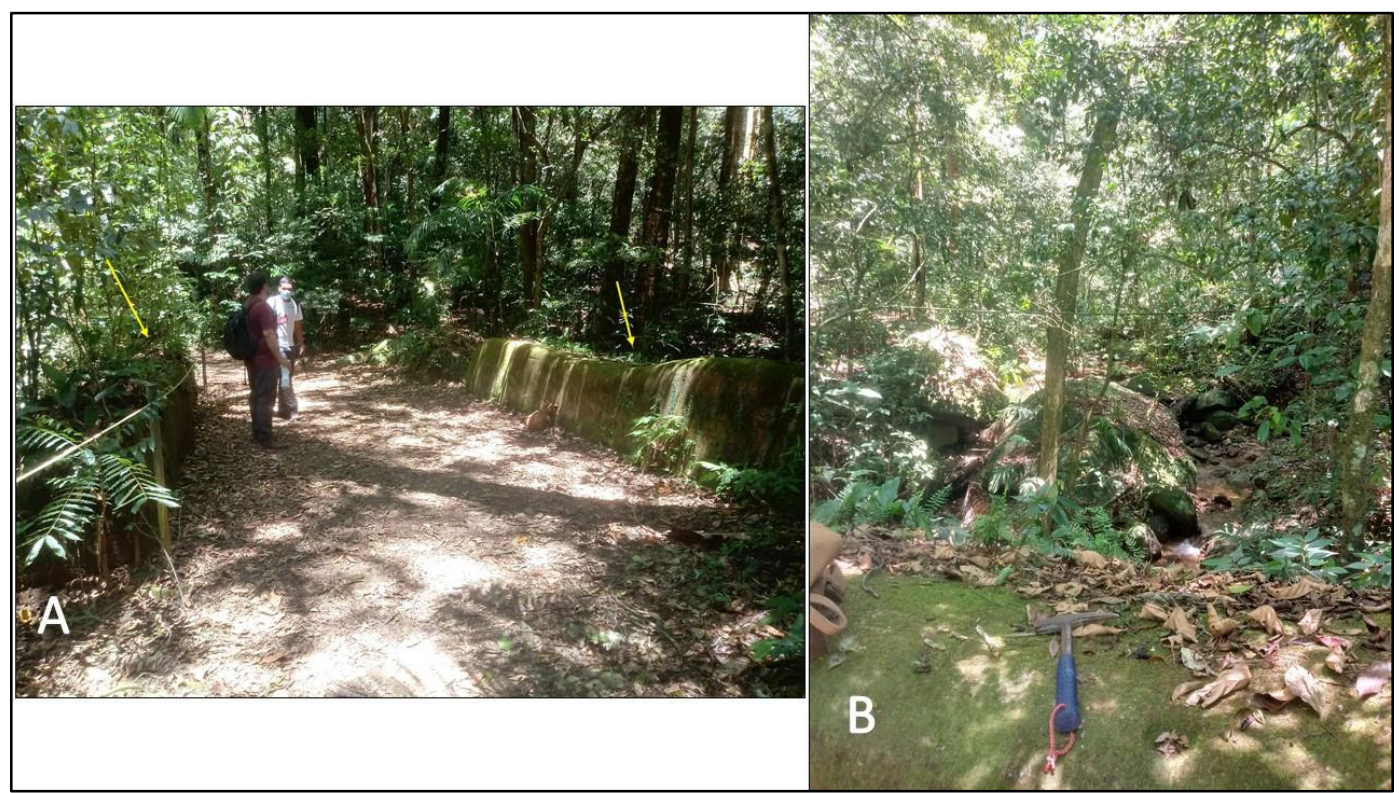

Figura 33: Ponte tosca no Caminho Pedro Augusto. A: Setas indicando as bordas da ponte; B- Rio Archer com bastante presença de tálus.

\section{Jardim dos Manacás}

Na ponta leste do Caminho Pedro Augusto ocorre o Jardim dos Manacás um ambiente de descanso e apreciação da floresta. Segundo Maia (1967) “este pequeno jardim foi guarnecido com arbustos que florescem no inverno- azaléas e manacásdaí o seu nome” (pág. 90).

O grande destaque neste local é a fonte Wallace, vinda da França, e as árvores ao seu redor (figura 34). Os aspectos de geodiversidade a serem explorados são: a captação de água pela fonte, a transição de compartimentos geomorfológicos, na qual se sai da planície aluvial para área de encostas íngremes rumo ao alto curso do rio Archer e, por fim, a conexão entre divisores de água, pois o jardim está instalado entre a bacia do rio Tijuca e bacia do rio da Solidão, caracterizado por ser um divisor rebaixado. 


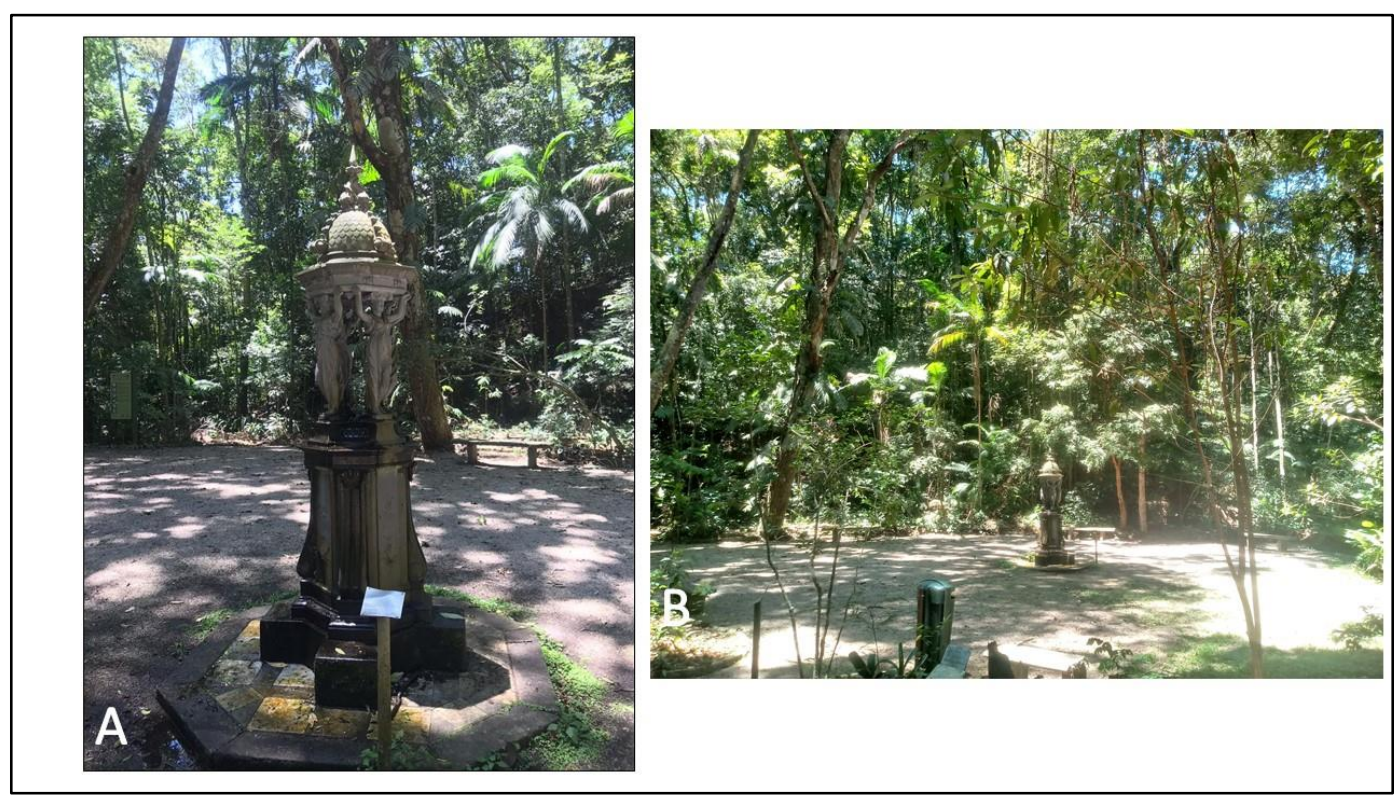

Figura 34: Jardim dos Manacás. A- Fonte Wallace. Fonte: Fernando Gomes; B- Visão geral do sítio.

\section{Gruta Lopes Mendes e Cascata Gabriela}

$\mathrm{Na}$ vertente de transição entre o Recanto dos Pintores e a estrada Major Archer, está situado o Caminho da Saudade, caracterizado por ser uma trilha plana e suave, com presença de depósitos coluviais e de tálus, interflúvios, cascatas efêmeras, gruta e knickpoints.

No meio deste caminho há a Gruta Lopes Mendes e a Cascata Gabriela (figura 35). A gruta é formada por blocos de ortognaisses vindos das avalanches detríticas provenientes do setor alto do Parque, onde encontram-se os maiores Picos do maciço, formados pelas litologias do Complexo Rio Negro. Os blocos são marcados por intrusões de veios de leucogranitos com pequenas dimensões.

A cascata Gabriela, por sua vez, apresenta piscina artificial, construída na gestão do Barão D'escragnolle e a drenagem é orientada pela fratura da rocha, identificada, segundo Roza (2007), como um bloco de Granito Favela, também identificado como proveniente dos picos mais elevados do Parque. Para jusante da Cascata Gabriela, a drenagem passa por baixo da Ponte Glaziou, uma importante estrutura histórica do Parque. Nesse ponto é possível verificar novamente a drenagem entalhando o leito fluvial em rocha, revelando afloramentos dos quartzitos que constituem o substrato sobre o qual o colúvio com blocos ou tálus estão depositados.

O presente sítio demonstra informações importantes acerca da geodiversidade, possibilitando ações geoturísticas, exaltando a dinâmica da 
paisagem, descrições sobre contatos litológicos, topografia, interflúvios e movimentos de massa (queda de blocos).

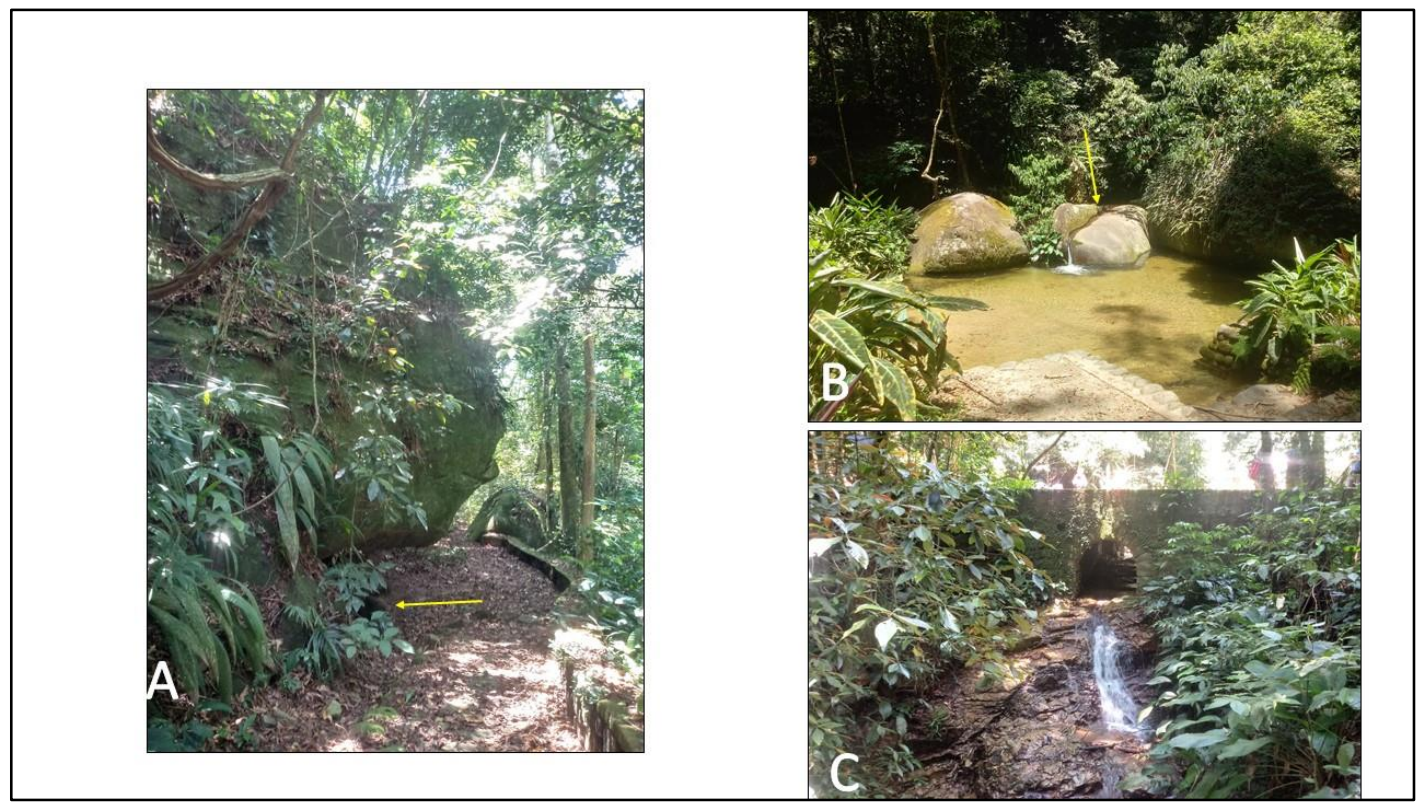

Figura 35: Gruta Lopes Mendes e Cascata Gabriela. A: Bloco que origina a Gruta Lopes Mendes, com seta que destaca a sua entrada; B- Cascata Gabriela, com seta indicando a fratura por onde a drenagem percorre; C- Ponte Glaziou e rio Archer com leito rochoso, formado por quartzito, localizado após a Cascata Gabriela.

\section{Alto da Bandeira}

A leste do portão de entrada da Floresta da Tijuca, está localizada o Morro do Alto da Bandeira (figura 36). O relevo é representado por cristas intermediárias (classe 9, vide mapa geomorfológico) e morro alto, sustentados, mais uma vez, por quartzitos. Este local é paralelo ao Morro do Alto Visconde, onde foi citado anteriormente o Mirante da Cascatinha, sendo separado pelo vale encaixado do rio Tijuca que se posiciona entre a Cascatinha de Taunay e a portaria deste setor do PNT.

As vistas para as Pedras da Gávea e da Agulhinha da Gávea, vale do Alto da Boa Vista, vertente reversa da Serra da Carioca e Oceano Atlântico são as grandes referências para o geoturismo nesse ponto. Sobre essa paisagem pode-se explorar o conteúdo a respeito da evolução tectônica e geomorfológica do relevo carioca, expondo processos relativos a quebra do continente Gondwana e abertura do Oceano Atlântico, bem como aspectos tectônicos e climáticos que auxiliaram na morfologia dos vales e compartimentação do relevo, além das estruturas tectônicas relativa às dobras e falhas regionais, capazes de explicar a ocorrência dos quartzitos ocupando os topos de morros. 


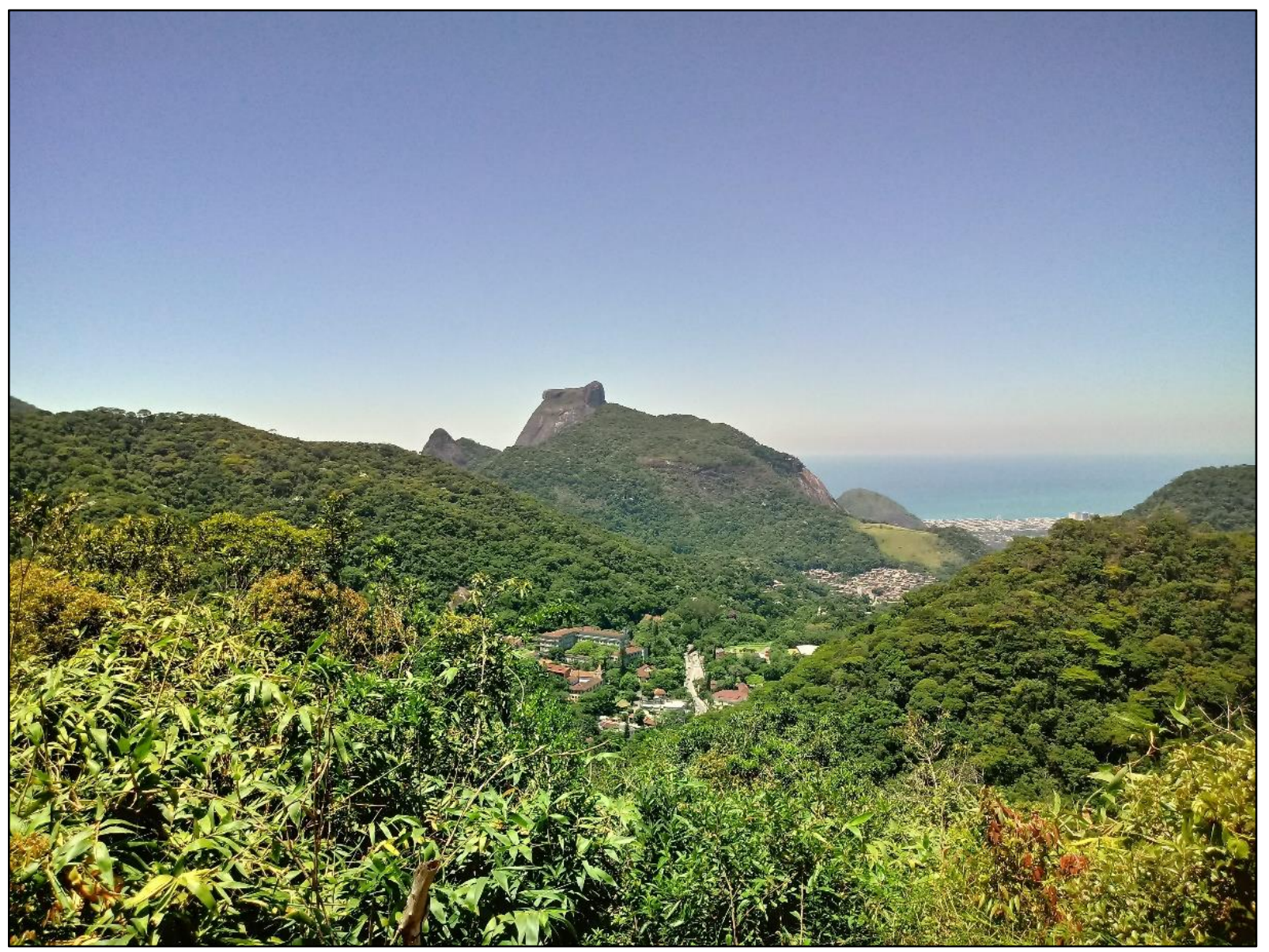

Figura 36: Vista da Pedra da Gávea, Agulhinha da Gávea e Vale do Alto da Boa Vista, a partir do Alto da Bandeira.

\section{Pedra do Conde}

A Pedra do Conde está acima do Morro do Alto da Bandeira e chega à cota de mais de 800 metros. Formada por Gnaisse Facoidal em seu topo, apresenta trilha de acesso com grau de dificuldade considerável a partir da bifurcação com o Caminho do Anhanguera. Nessa trilha é possível notar afloramentos rochosos das diversas litologias que ocorrem no Grupo São Fidélis até o corpo intrusivo do Gnaisse Facoidal no topo da montanha (figura 37).

Em seu topo, possui pontos de observação para a exuberante paisagem carioca, com vistas para a Baía de Guanabara e para o Oceano Atlântico ao sul. O sítio se torna importante não somente por ser um excelente local de observação, mas também pela sequência de litologias que revela ao longo de sua subida, incluindo o importante Gnaisse facoidal em uma de suas raras ocorrências no interior desse setor da Floresta da Tijuca. Esta rocha possui contato com os quartzitos do Grupo São Fidélis e a diferença entre o relevo é perceptível na paisagem, pois a resistência aos processos de intemperismo dessa unidade litológica 
é maior, gerando relevo com maior altitude, vinculado ao domínio serrano (DANTAS, 2018). No mapeamento geomorfológico com uso do índice de posição topográfica, a área é classificada como cristas elevadas e topos elevados (classe 10).

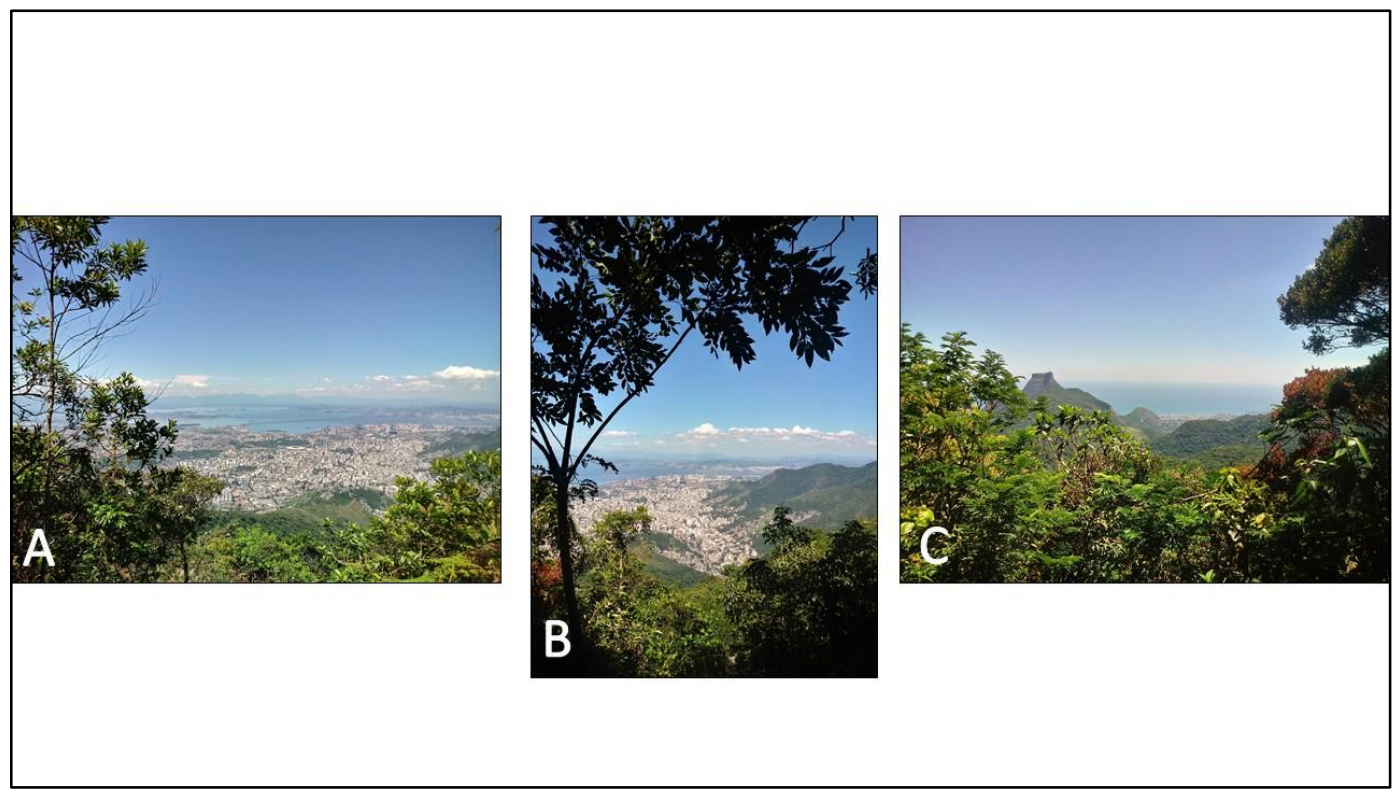

Figura 37: Vistas a partir da Pedra do Conde. A- Vista para Baía de Guanabara e parte da Zona Norte Carioca; B- Ponto de observação

\section{Morro do Anhanguera}

Acima do Mirante do Excelsior, há o Morro do Anhaguera. O acesso se dá pelo caminho do Anhaguera, após a bifurcação para a Pedra do Conde. Também há acesso pela Estrada do Excelsior, onde há bifurcação a direita para trilha

A subida apresenta pequenos e médios blocos de quartzitos e pouco desenvolvimento de manto de intemperismo, e é possível observar nitidamente o vale do alto curso do rio Maracanã e parte da vertente reversa e topo da Pedra do Conde. A vegetação mais seca que nas áreas com as demais litologias citadas, devido aos solos rasos e poucos férteis. Este sítio é um divisor de drenagem tríplice, pois os materiais e drenagens escoam para as bacias dos rios Tijuca, Excelsior e Maracanã. Em seu topo há eucaliptos, vegetação que não é nativa da Mata Atlântica, instalada durante a gestão do Barão D'escragnolle. Devido as características da vegetação, apresenta suscetibilidade e risco a incêndios.

O sítio Morro do Anhanguera (figura 38), como em outros sítios é um excelente local de estudo e apresentação de divisores das bacias hidrográficas, história ambiental (devido as intervenções antrópicas na vegetação), dinâmica hidrológica em áreas com quartzitos e evolução do lineamento central do Maciço da Tijuca, no qual é possível observar do sítio. 


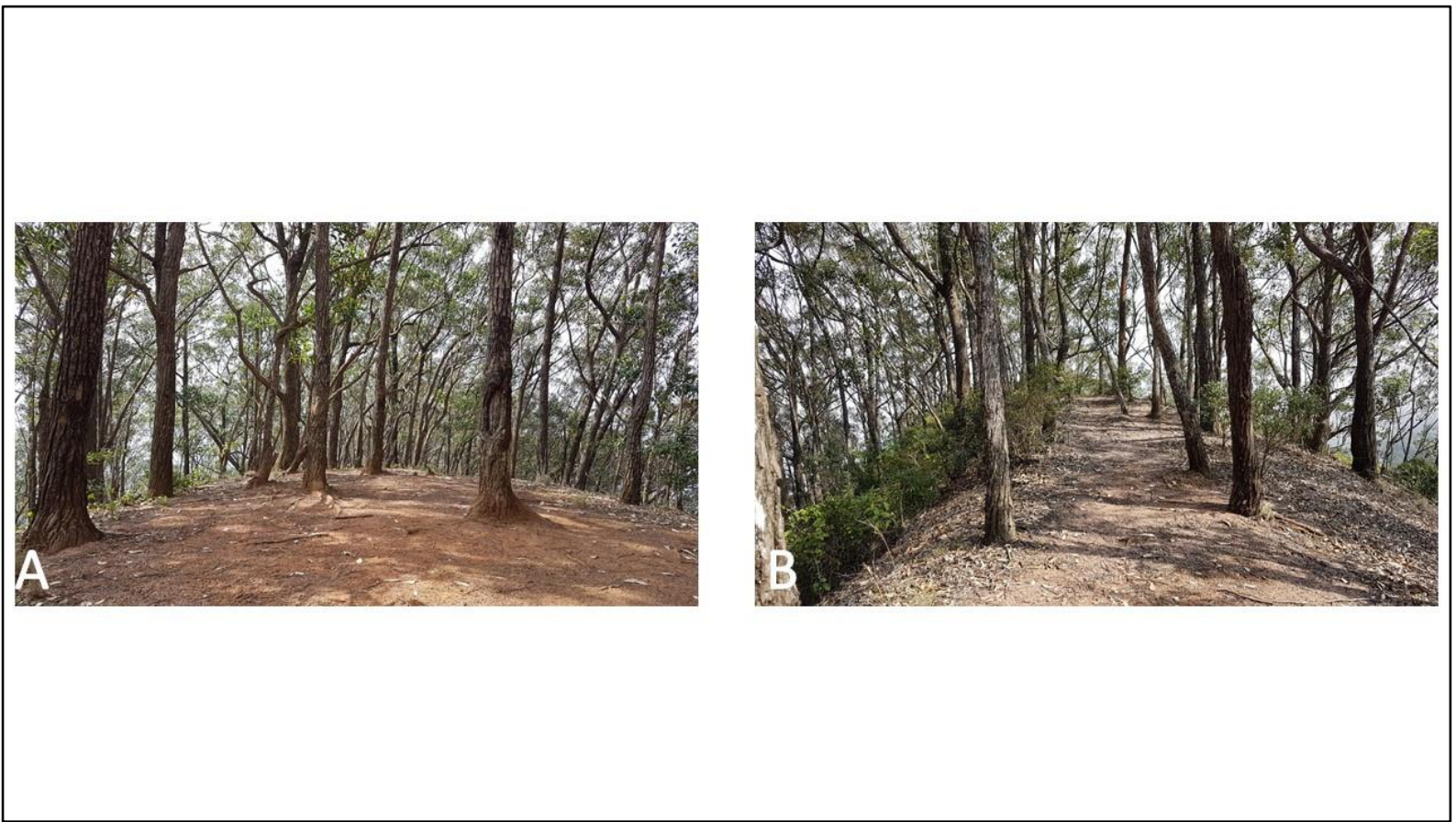

Figura 38: Alto da Bandeira. A: Topo do Morro do Anhaguera com maior arredondamento; B:

Topo do Morro do Anhaguera, com destaque ao afunilamento do divisor de águas das bacias do rio Maracnã, Tijuca e Excelsior. Fonte: Wikiloc. Disponível em: https://pt.wikiloc.com/trilhastrekking/pnt-travessia-bom-retiro-portao-da-floresta-via-caveira-com-5-cumes-26246881. Acesso em 15/05/21.

\subsection{3) Setor Alto}

\section{Gruta do Belmiro}

Na parte noroeste da bacia, situado na sub bacia do rio Archer, ocorre uma área cercada por inúmeros depósitos de tálus, no sopé do Morro do Archer. Configura-se em uma vasta área de depósitos de blocos de grande volume e em grande quantidade, formando um sistema de grutas e abrigos entre eles. $\mathrm{O}$ sistema é um dos grandes atrativos do PNT, tendo grande visitação. A Gruta do Belmiro (figura 39) representa uma destas cavidades formada entre blocos de gnaisse da unidade Gnaisse Archer, pertencente ao Complexo Rio Negro. No mapa de padrão de relevo de Dantas (2019), o local é identificado como rampas de colúvio-tálus. Segundo a classificação obtida pelo índice de posição topográfica, na área predomina a classe 6: posições intermediárias das vertentes, compartilhando espaço com algumas áreas planas (classe cinco) e topos rebaixados, interflúvios, cristas intermediárias ou morro em áreas planas (classe nove). Segundo o mapeamento de Lumbreras e Gomes (2004), na área são encontrados latossolos, dada a escala de mapeamento, porém no campo naturalmente encontra-se a classe dos cambissolos e esta. 
A geologia se apresenta rica do ponto de vista litológico e estrutural, pois há presença de inúmeros veios graníticos intrudidos no Gnaisse Archer e chama atenção a foliação desta rocha. Há a possibilidade de desenvolver planos de geoturismo para esta área, que também não explicita informações sobre temas que potencialmente podem ser tratados na área. Entre tantos destaca-se o processo de formação das grutas, fornecendo debates sobre movimentos de massa (quedas de blocos), o papel hidrológico que as grutas exercem nas encostas e caracterização da rocha que as compõem.

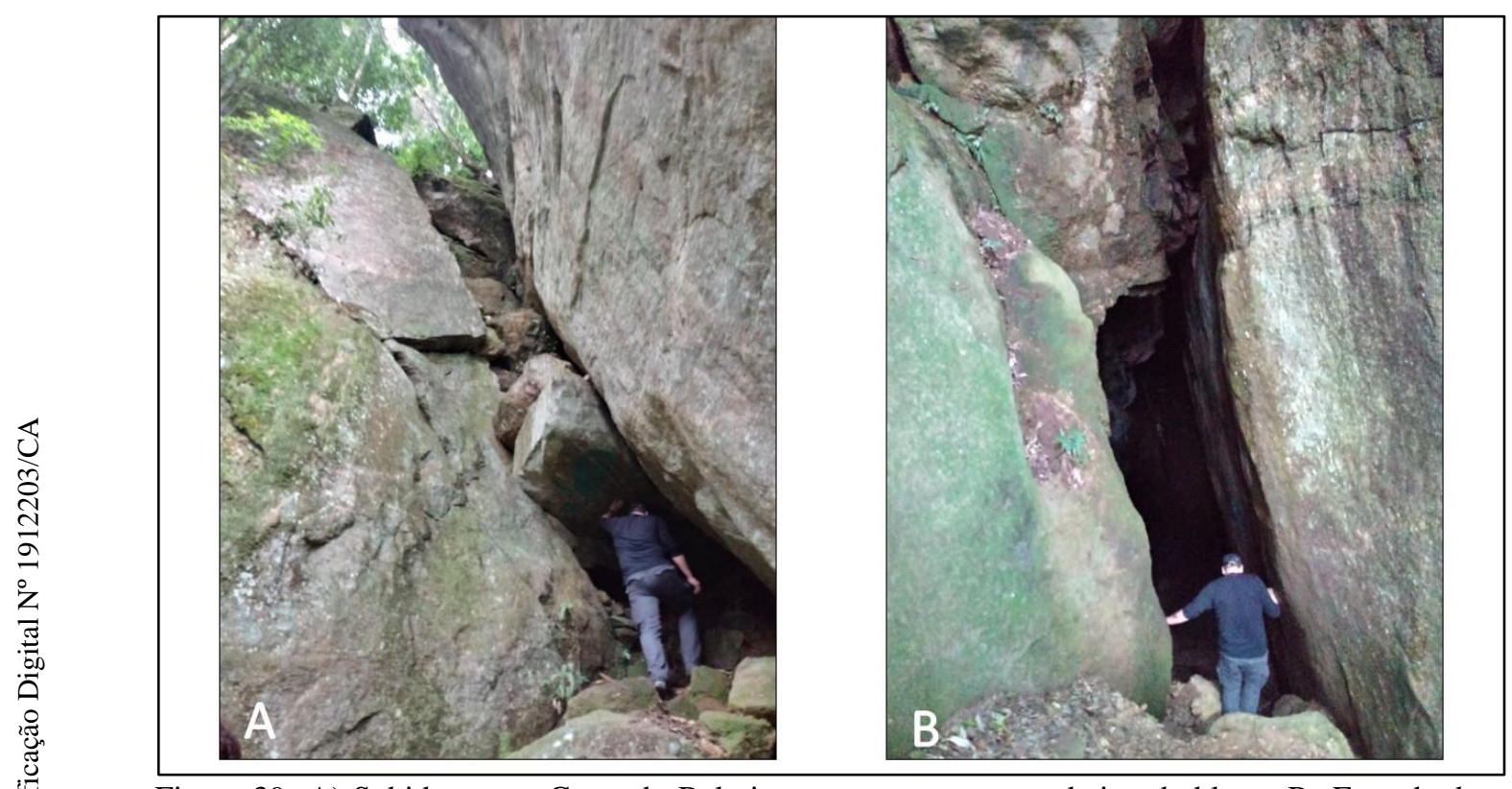

Figura 39- A) Subida para a Gruta do Belmiro, com passagem por baixo de bloco; B- Entrada da Gruta.

\section{Gruta dos Morcegos}

O presente sítio está no meio do Circuito das Grutas, apresentando pequena entrada e um grande salão. O seu teto tem uma abertura onde entra a iluminação. As paredes são formadas por imensos blocos em forma de "lascas" onde o Gnaisse Archer (Complexo Rio Negro) apresenta espetaculosas feições geológicas, como diques e sills de leucogranitos intrudidos e marcante foliação mineral (figura 40).

Devido a sua escuridão, é recomendável utilizar objeto luminoso para observar seu interior. No fundo da gruta há blocos menores rolados em formato de depósitos pelas fendas dos blocos maiores. Além das características naturais que atraem visitantes em geral, a valorização da geodiversidade do sítio se torna necessária, como forma de incremento a visitação e também o fortalecimento da 
percepção geocientífica para sua conservação, na qual elucida principalmente a dinâmica de queda de blocos e a gênese de intrusões.

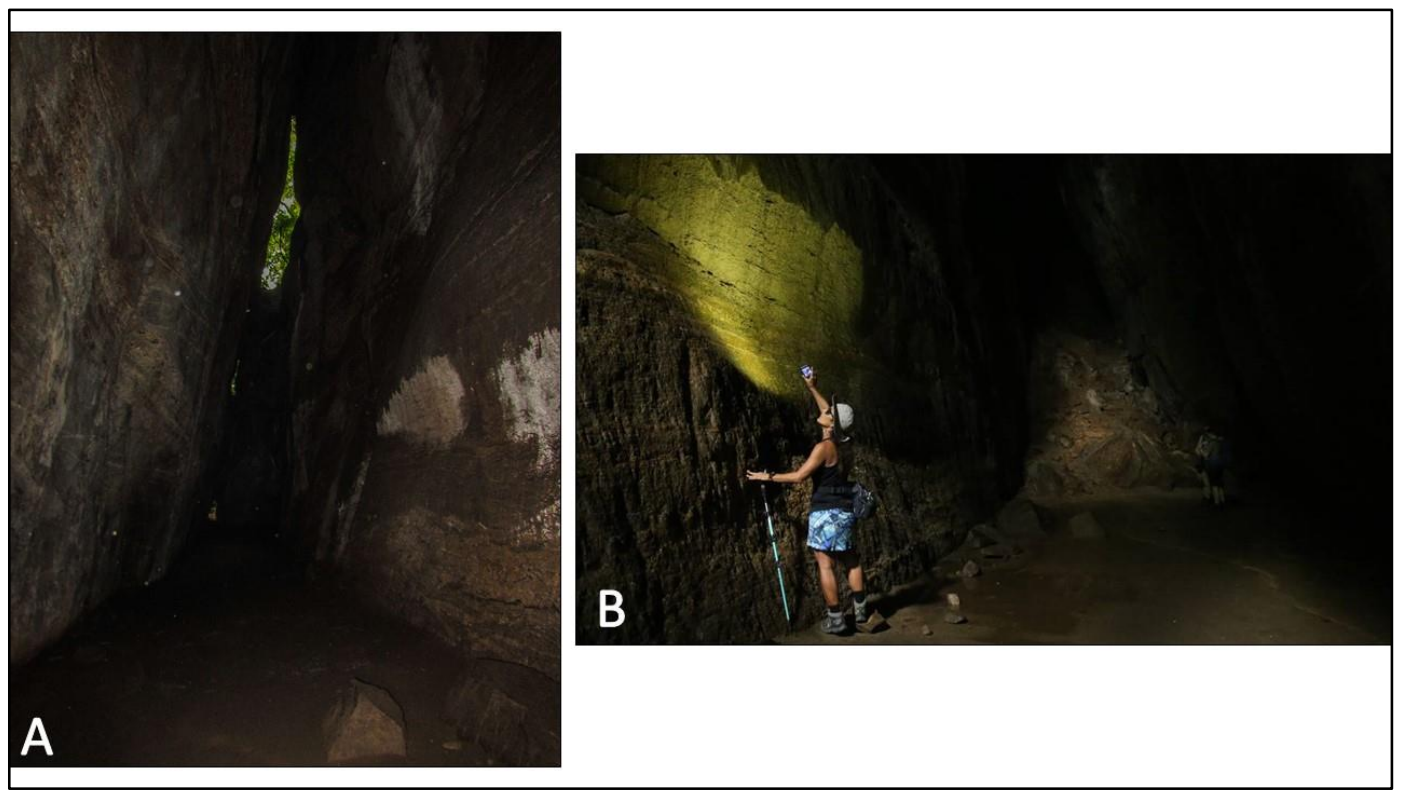

Figura 40: Gruta dos Morcegos. A- Perspectiva do fundo da gruta, com destaque a presença de veios graníticos. Fonte: Vamos Trilhar. Disponível https://www.vamostrilhar.com.br/aventuras/conheca-tudo-sobre-o-circuito-das-grutas-da-florestada-tijuca-rj/. Acesso em: 15/05/21; B- Visão da gruta a partir da sua entrada. Fonte: Jornal O Globo. Disponível em: https://oglobo.globo.com/rio/conheca-alguns-recantos-pouco-visitados-do-parquenacional-da-tijuca-24279582. Acesso em 15/05/21.

\section{Campo Escola 2000}

O Campo Escola 2000 é um importante centro de prática de escalada, também instalado no Circuito das Grutas (figura 41). É representado por um grande bloco de Gnaisse Archer. O bloco possui inclinação invertida, conhecida por escaladores como parede negativa. Os veios, a foliação mineral e as fraturas definem as garras e locais de apoio para as vias de escalada que ficam marcadas pelo pó de magnésio usado na prática do esporte. Devido a grande dimensão do bloco, é possível investigações científicas, turísticas e escolares na sua frente e em suas partes laterais. A junção entre prática de esporte e geoturismo se torna uma importante ferramenta de ação e conscientização sobre conservação ambiental, morfogênese e aspectos geológicos. 


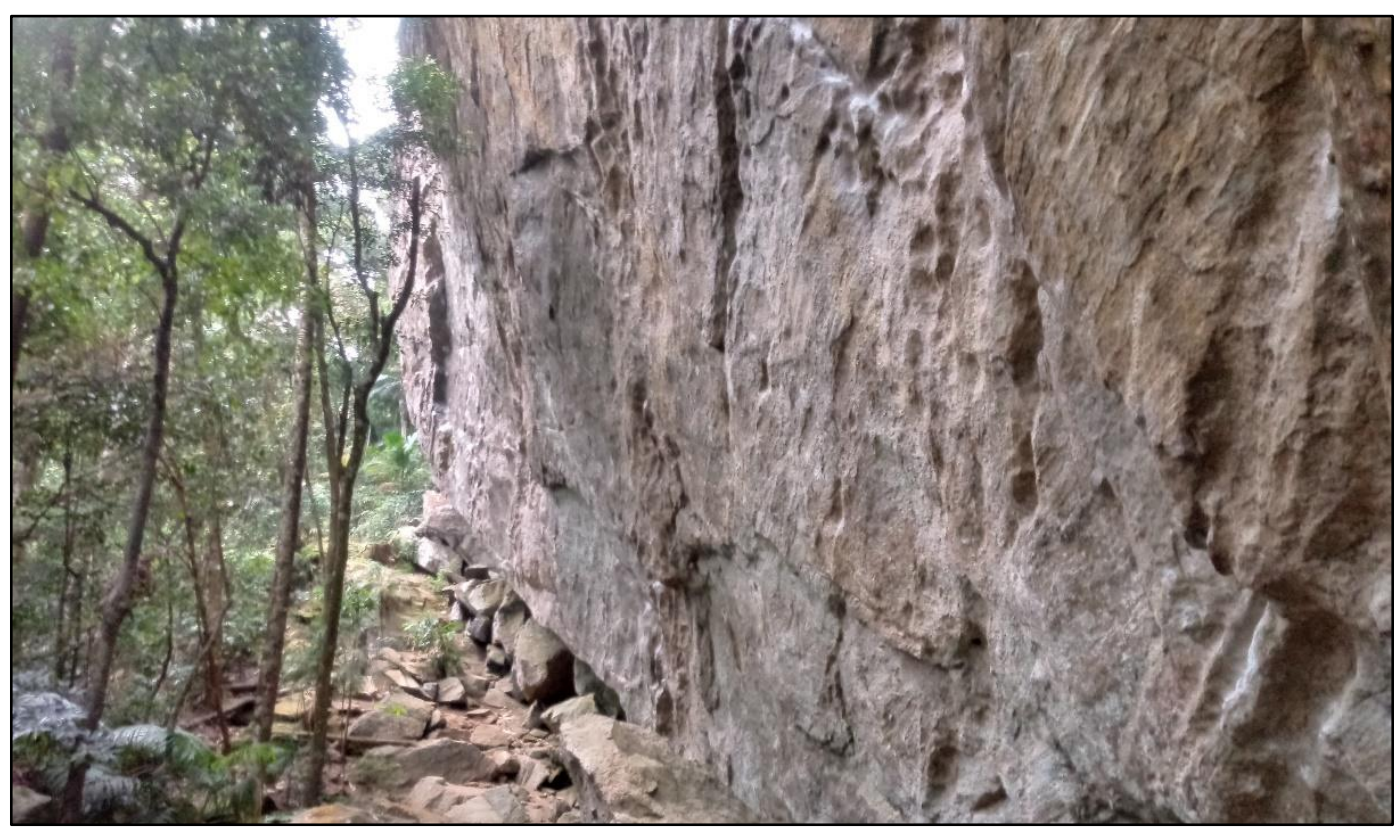

Figura 41: Sítio de Geodiversidade Campo Escola.

\section{Cachoeiras do Alto Curso do Rio Archer e Gruta Paulo e Virgínia}

O presente sítio demonstra caráter múltiplo, pois apresenta mais de uma atração geoturística. Ao longo da drenagem do rio Archer, este ponto é formado por uma sequência de quedas d'água com destaque para as Cascatas Diamantina e da Baronesa e pela Gruta Paulo e Virgínia (figura 42).

As cachoeiras apresentam características diferentes: a Cascata Diamantina possui duas quedas sobre afloramento de ortognaisse, enquanto a da Baronesa a drenagem escoa sobre afloramentos e blocos desta rocha.

As Grutas, além de proporcionarem abrigo e encantamento por sua formação em meio de imensos blocos rochosos, exibem atributos geológicos em suas paredes como dobras e veios.

As descrições mencionadas e observações de campo, puderam fornecer informações para que se promova a valorização do conteúdo científico para a informação geoturística, bem como sua geoconservação, pois todos os atrativos estão vinculados a traços geomorfológicos e geológicos, sendo importante tanto para o âmbito científico como social. Há também estrutura de apoio, denominado Recanto Paulo e Virgínia, com bancos para descanso e lazer, estacionamento e banheiros. 


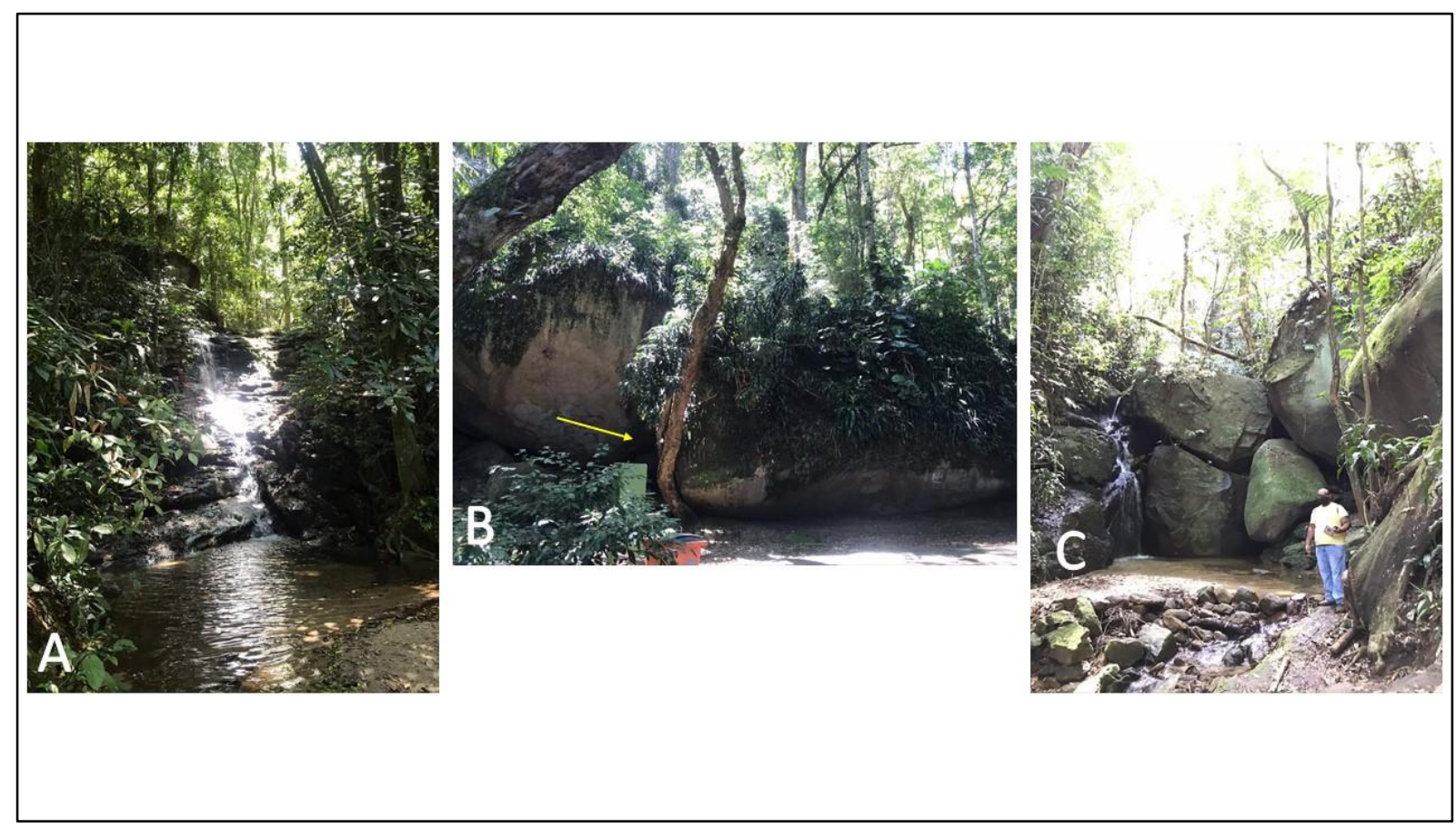

Figura 42: Cachoeira do alto curso do rio do Archer e Gruta Paulo e Virgínia. A- Cascata Diamantina; B- Seta indicando entrada da Gruta Paulo e Virgínia; C- Cascata da Baronesa.

\section{Vista do Almirante}

Ao longo da Estrada Major Archer é possível observar a transição da compartimentação do relevo, e o Mirante do Almirante é um dos melhores pontos para esta inspeção. O nome do local é homenagem ao Almirante Beaurepaire, sogro do Barão de Escragnolle (MAIA, 1967). Do local, se tem vista para as Pedras da Agulhinha e da Gávea, parte do setor médio da bacia do rio Tijuca e da vertente reversa da Serra da Carioca (figura 43).

Representa um limiar hipsométrico/geomorfológico, pois está entre as rampas coluviais e de tálus em direção ao Circuito das Grutas e a vertente de contato geológico (entre o Grupo São Fidélis e Complexo Rio Negro) e geomorfológico (de acordo com a classificação IPT, topos rebaixados e áreas situadas nas posições intermediárias das vertentes), que apresenta característica abrupta até chegar ao vale aberto e planície aluvial que conecta o Caminho Pedro Augusto ao Vale das Almas. 


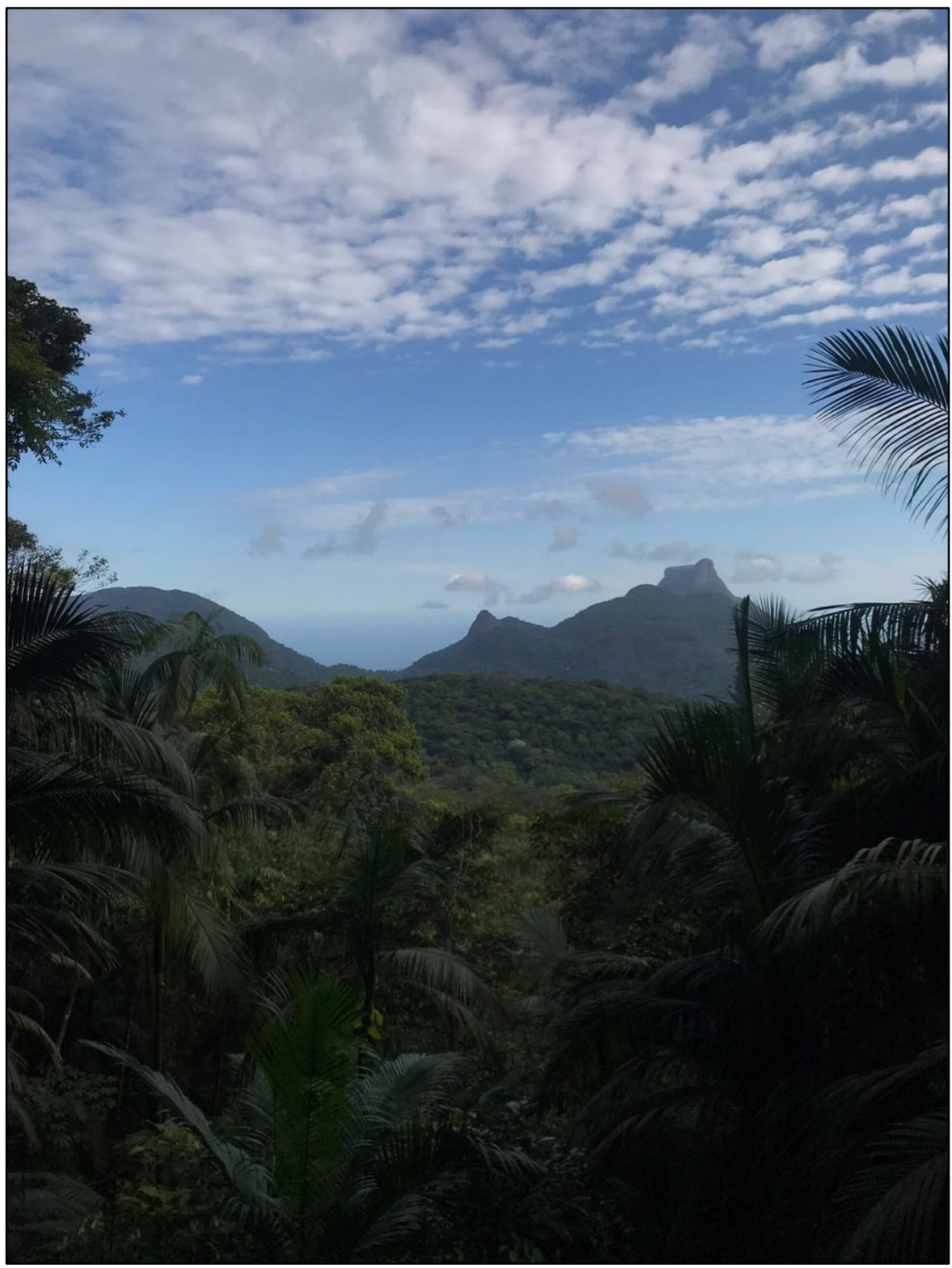

Figura 43: Vista do Almirante.

\section{Lago das Fadas}

No início do Setor Alto e com acesso principal pela Estrada dos Picos, o Lago das Fadas é um recanto de lazer e contemplação. O substrato geológico novamente é formado por quartzitos, com relevo de topos rebaixados e áreas intermediárias das vertentes, pouca presença de solo e captação de água para consumo humano e para o lago (figura 44).

O Lago é artificial e possui algumas espécies de peixes. Está na parte oeste da bacia do rio das Almas, próximo ao divisor de drenagem com a bacia do rio do Archer e também está perto da zona de contato entre os conjuntos de rochas paraderivadas e ortoderivadas supracitados. $\mathrm{Na}$ área do playground, é possível 
observar pequenos blocos de quartzito. O uso antrópico da água e a organização das classes de relevo são elementos-chave para a divulgação da geodiversidade local.

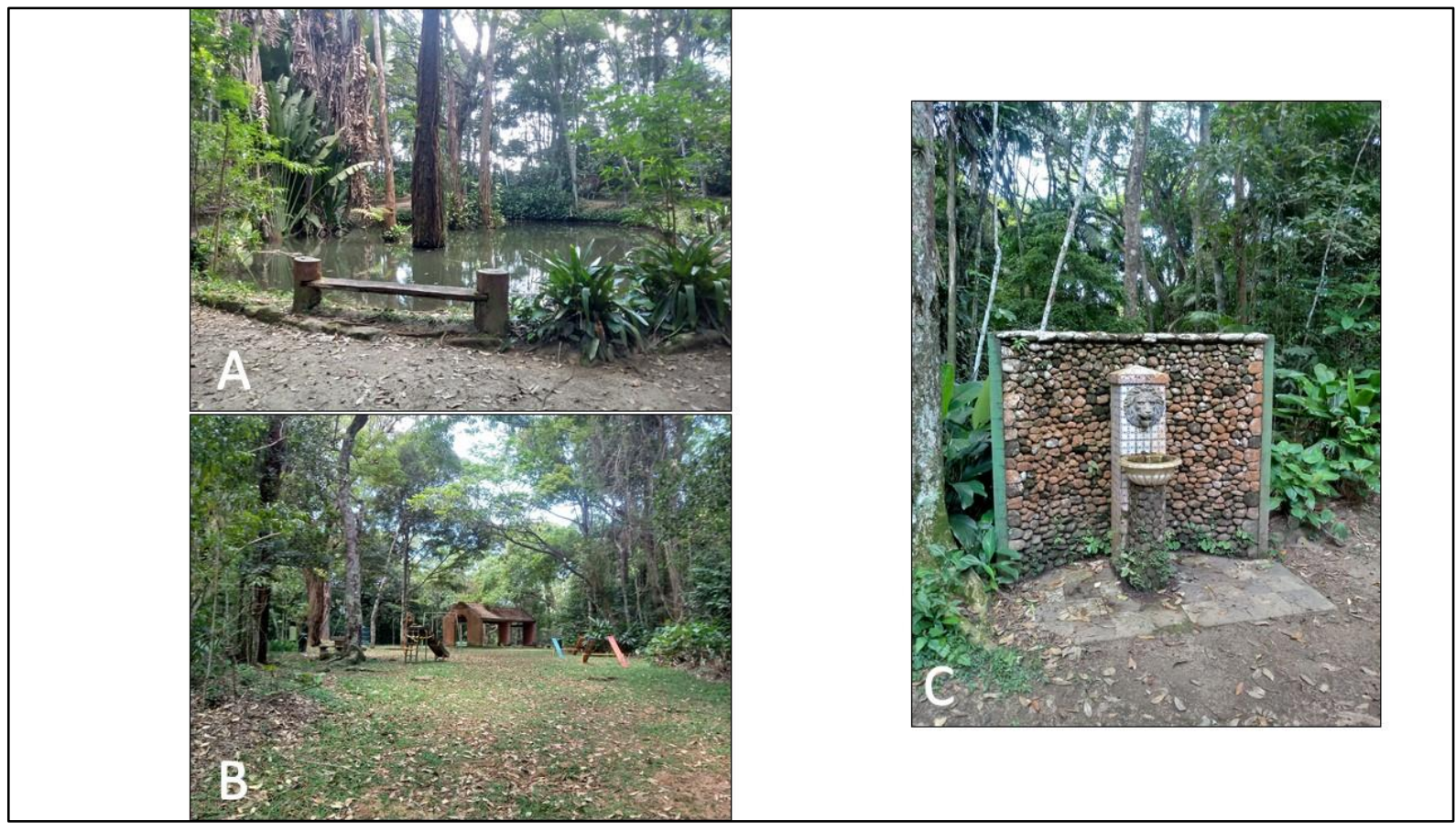

Figura 44: Sítio de Geodiversidade Lago das Fadas. A- Lago das Fadas; B- Playground, localizado ao lado do lago; C- Bebedouro.

\section{Cachoeira das Almas}

Este sítio está localizado no rio das almas e bacia homônima. Trata-se de uma cachoeira (knickpoint) sobre ortognaisse Archer, onde ocorrem diversos planos de fraturas e depósitos de tálus dispostos em sua proximidade. É um famoso destino do do PNT com intensa visitação pois é uma das cachoeiras onde é permitida balneabilidade (figura 45).

A denominação Almas vem de práticas religiosas, realizadas a época dos escravos. O vale do rio das Almas é encaixado e está em grande parte inserido no Complexo Rio Negro. Para acessar a Cachoeira das Almas, o visitante pode percorrer variados caminhos, porém o principal é o Caminho das Almas. Apresenta particularidades importantes para estudos e divulgação científica de hidrologia, geologia estrutural e geomorfologia. 


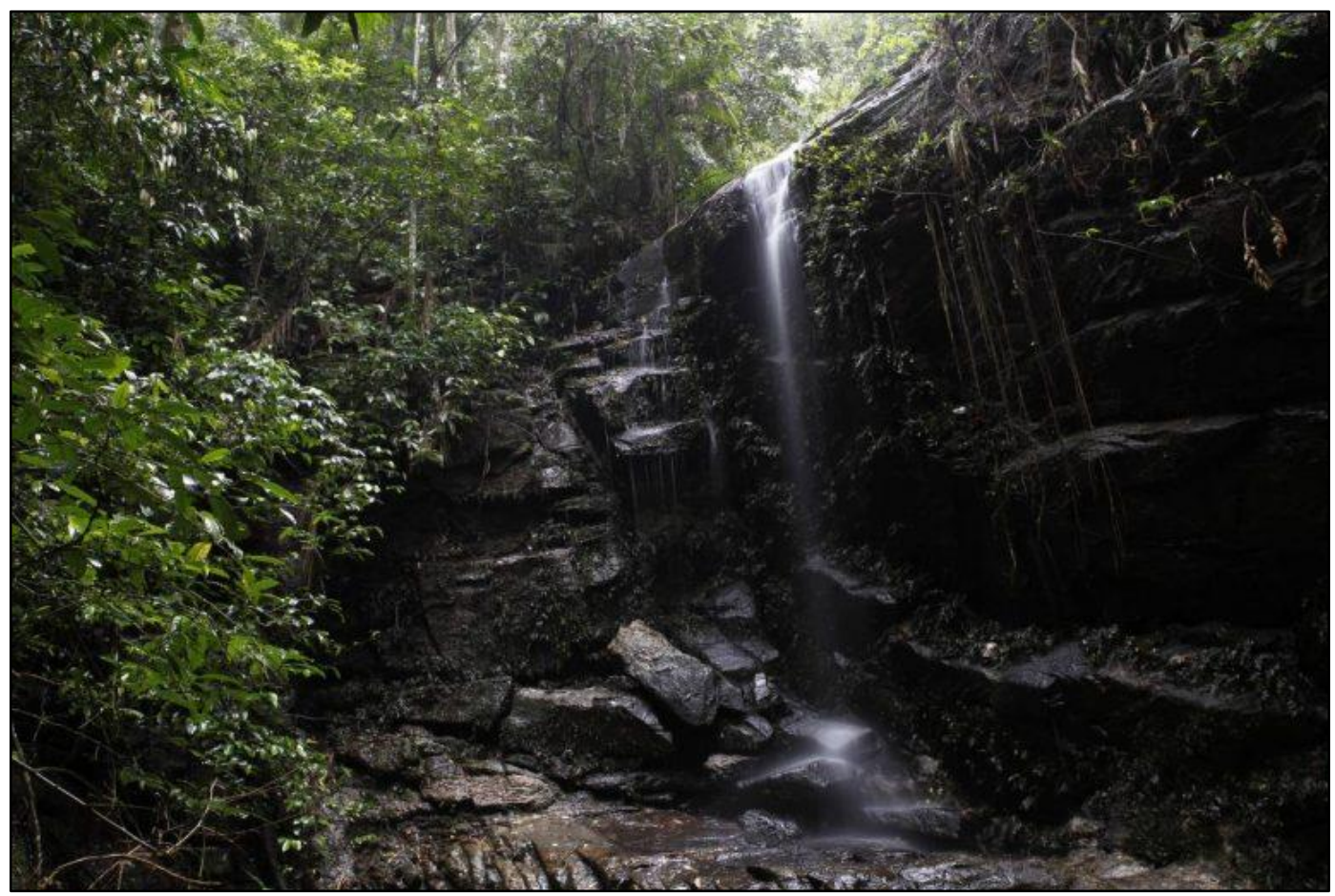

Figura 45: Cachoeira das Almas. Fonte: Parque Nacional da Tijuca. Disponível em: https://parquenacionaldatijuca.rio/locais/cachoeira-das-almas/. Acesso em: 15/05/21.

\section{Caminho de Pedra da Serrilha da Caveira}

Na Serrilha da Caveira, que liga a Estrada do Excelsior até a trilha dos Picos da Tijuca, Tijuca Mirim e Andaraí Maior, há um trecho calçado com blocos rochosos de ortognaisse. Não se sabe detalhes sobre a construção deste empreendimento, mas supõe que possa datar da época em que fazendas estavam instaladas sobre a hoje conhecido PNT e provavelmente construído por escravos (figura 46).

É um típico sítio de geodiversidade ex situ. Este fato mostra que os elementos abióticos são utilizados há muito tempo pelas sociedades. O sítio se torna fundamental para o resgate histórico não somente sobre o período de escravidão, mas também sobre a dinâmica econômica dentro do maciço antes do reflorestamento e da instalação de uma unidade de conservação. 


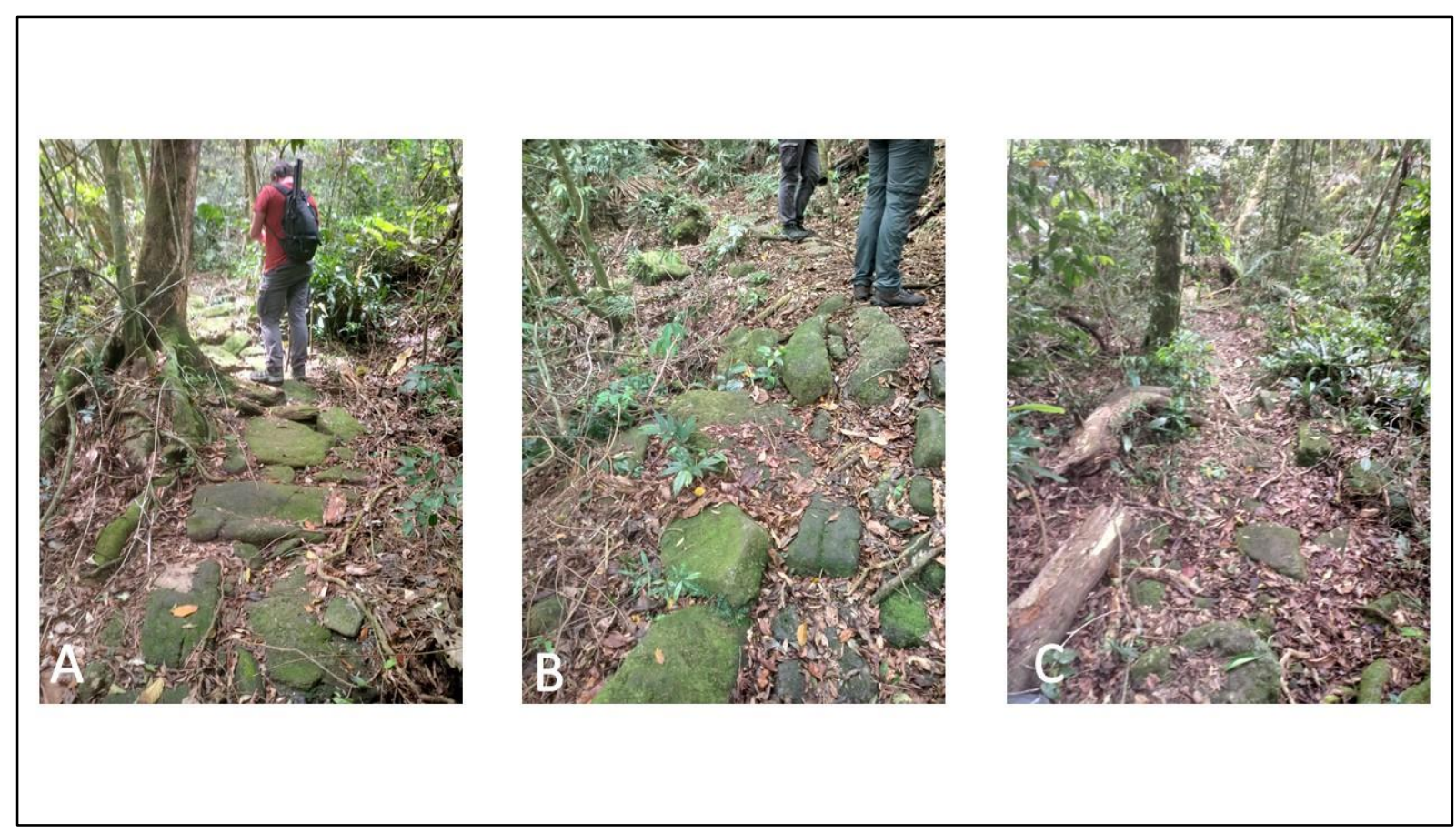

Figura 46: Caminho de Pedra da Serrilha da Caveira. A- Visão a partir do início do trecho com blocos rochosos; B- Meio do caminho; C- Final do trecho.

\section{Pico Andaraí Maior}

$\mathrm{Na}$ ponta nordeste da bacia ocorre o Pico do Andaraí Maior, também denominado Pico da Caveira. Tanto na parte final da sua trilha como no ponto de chegada, há vista para a Zona Norte do Rio de Janeiro, Maciços do Medanha e Pedra Branca, Baía de Guanabara, Baixada Fluminense e Serra do Mar (figura 47).

A geologia é caracterizada pela presença do gnaisse Archer, com textura porfiroblástica, alguns veios e pequena falha sobre estes. É um dos sítios mais ricos de informações, em especial, sobre a geomorfologia, definida no mapeamento como crista elevada (classe 10). A vegetação seca está presente em afloramento com alta declividade, sem desenvolvimento de solos. Outro destaque importante se dá pela observação dos Vales das bacias hidrográficas dos rios dos Ciganos e Perdido.

O acesso se dá pelas trilhas que dá acesso aos picos da Tijuca e Tijuca Mirim, Vale do Perdido e pela Serrilha da Caveira. Não é recomendável a ida de muitas pessoas em um mesmo grupo, pois o sítio apresenta área pequena. Há também gruta homônima em sua base, com acesso pouco sinalizado. É muito útil para a difusão do conhecimento geocientífico, onde se pode elucidar sobre a formação e desenvolvimento da Serra do Mar, do Rift da Guanabara, dos Maciços Cariocas e história social da Região Metropolitana do Rio de Janeiro. 


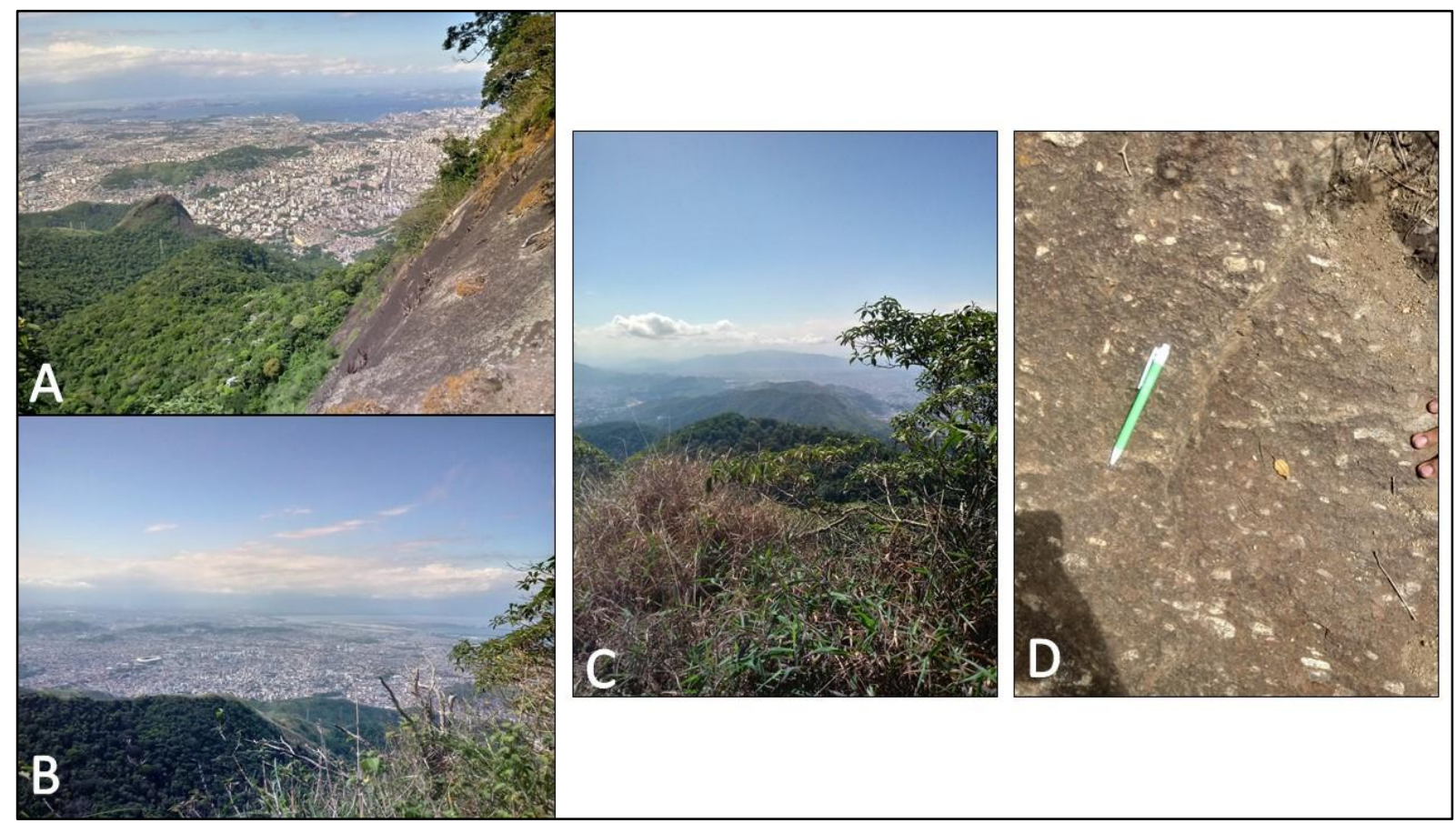

Figura 47: Pontos de observação a partir do Pico do Andaraí Maior. A- Vista para a Zona Norte do Rio de Janeiro, Baía de Guanabara e Serra dos Orgãos; B- Meio do caminho, onde é possível observar a Zona Norte; C- Parte da trilha, na qual se observa os Maciços da Pedra Branca e Mendanha.; D- falha normal.

\section{Base do Pico Tijuca Mirim}

Na trilha entre os Picos do Andaraí Maior e Tijuca Mirim, há no sopé deste último, um suntuoso afloramento de ortognaisse com ocorrências de diques, sills, gruta, fraturas, falha, dobras e detalhes de crenulação. Como forma de facilitar a compreensão e gestão do parque, o sítio foi denominado como Base do Pico Tijuca Mirim (figura 48).

O local também possui pontos de observação da paisagem como o Pico do Andaraí Maior, Zona Norte e outras partes da Floresta da Tijuca. A litologia apresenta bandamentos e diferentemente do gnaisse encontrado no Pico do Andaraí Maior, a textura porfiroblástica não se destaca, haja visto que o gnaisse Archer apresenta variações intrínsecas (vide contexto geológico e geomorfológico).

A presente área é um importante palco de investigações e geoconservação. A pichação é o aspecto negativo encontrado. A ocupação de vegetação em pontos fraturados no afloramento possui relevância, pois mostra as interações entre os elementos bióticos e abióticos, reconfirmando que a geodiversidade é a base para o estabelecimento da vida na Terra. 


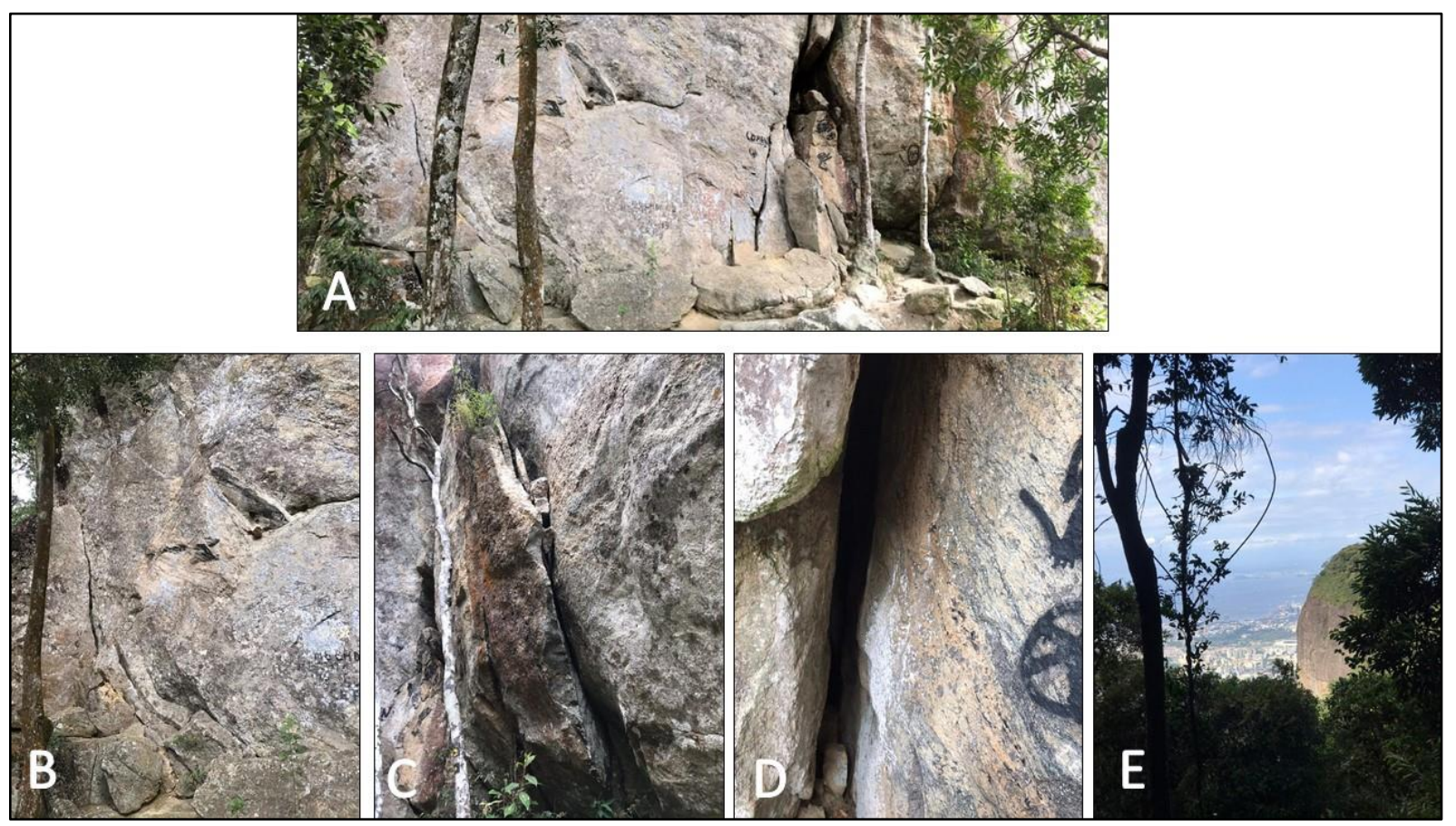

Figura 48: Base do Pico Tijuca Mirim. A- Visão da chegada ao afloramento; B- Destaque para fraturamentos; C- Vegetação próxima e sobre a rocha fraturada; D- Entrada para gruta com pichação; E- Vista para Pico do Andaraí Maior, Zona Norte e Baía de Guanabara. Autoria: Fernando Gomes.

\section{Pico Tijuca Mirim}

O Sítio de Geodiversidade Pico Tijuca Mirim, é um dos pontos mais altos da Floresta da Tijuca. Está localizado ao lado do Pico da Tijuca. Do seu topo se ver a parte leste e nordeste do setor A, vertente reversa da Serra da Carioca, parte da Zonas Norte e Central do Município do Rio de Janeiro e Baía de Guanabara (figura 49).

Em seu topo ocorre afloramento com fraturas e estreito manto de intemperismo. O relevo é caracterizado pelas cristas elevadas, declividade alta nas bordas e menos acentuada em seu topo. O presente sítio apresenta itens para atividades de geoturismo e visão panorâmica, que incrementa a visitação. Também pode ser um ponto de interesse climático, onde se observa a dinâmica das nuvens e ventos. 


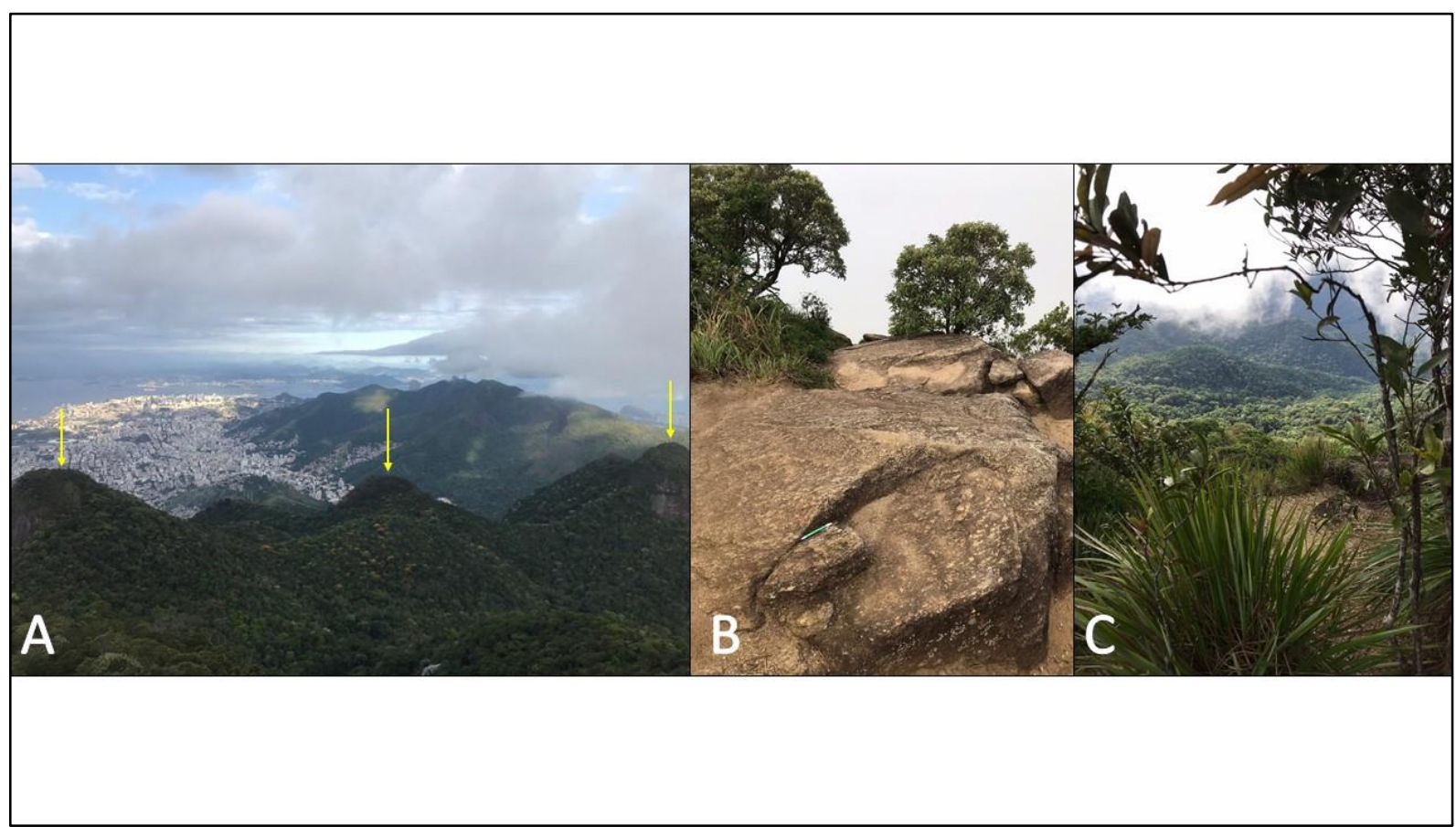

Figura 49: Sítio Pico Tijuca Mirim. A- Mirante, onde é possível observar os locais marcados com as setas amarelas, que indicam os Picos do Andaraí, Morro do Anhaguera e Pedra do Conde. Ao fundo, estão a vertente reversa da Serra da Carioca, Bairro da Tijuca, Zona Central do Rio de Janeiro e Baía de Guanabara; B- Afloramento de ortognaisse no topo do Pico; C- Vista para parte do alto curso do rio Tijuca. Autoria: Fernando Gomes.

\section{Pico da Tijuca}

O Pico da Tijuca é o ponto de mais alto do Parque Nacional da Tijuca e do Município do Rio de Janeiro, estando a sua vertente sul, para a bacia hidrográfica do rio Tijuca e a norte, para a bacia hidrográfica do rio dos Ciganos. É um dos picos que mais atraem visitantes.

O início para subida do Pico se dá em escada construída em rocha, por ocasião da visita da comitiva do Rei Alberto da Austria, em 1920. No topo, houve desenvolvimento de manto de intemperismo, devido a declividade baixa. A geomorfologia é caracterizada por ser topo e crista elevada e sua base é representada por um contraforte de grande dimensão (figura 50).

Neste sítio há três diferentes pontos de observação, nos quais é possível ver a Zona Norte e parte considerável das Zonas Oeste e Sul, Região Metropolitana e Serra do Mar. Há placa explicativa sobre a Trilha Transcarioca. Assim como no Pico Tijuca Mirim, o local também é indicado para observação da dinâmica climática. As discussões sobre a quebra do Gondwana, formação do Rift da Guanabra e Serra do Mar, podem ser conduzidas em seu topo, dada a visão regional desses aspectos, assim como a relação entre vegetação e relevo, histórico de 
ocupação do Rio de Janeiro, entre outros aspectos, compondo as ações de geoturismo.

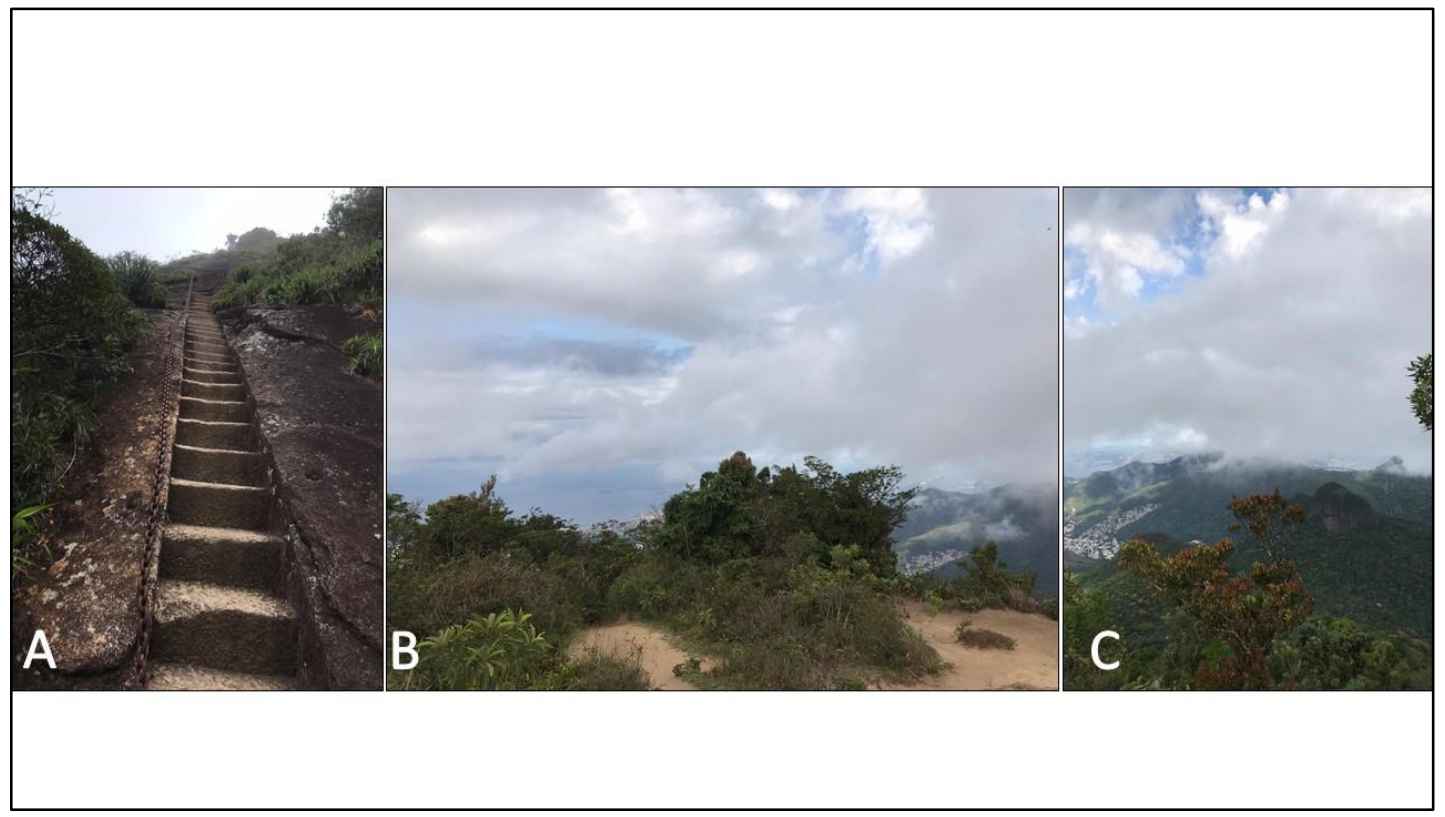

Figura 50: Sítio Pico da Tijuca. A- Escadaria sobre afloramento de ortognaisse; B- Topo com vegetação rasteira e manto de intemperismo e ponto de observação para a Zona Norte e Baía de Guanabara; C- Visão para o bairro da Tijuca e Serra da Carioca.

\section{Morro do Archer}

Na trilha que liga o Largo do Bom Retiro ao Bico do Papagaio, ocorre desvio para a esquerda em direção ao cume do Morro do Archer (figura 51). O presente sítio de geodiversidade é coberto por vegetação densa, na qual gera vista reduzida em comparação aos picos supracitados.

As classes de relevo variam entre posições superiores das vertentes, topos rebaixados e elevados (vide mapa geomorfológico da bacia). Ainda que tenha limitações, como vista não panorâmica, é um local de interessa para o geoturismo, pois é um local de visitação por caminhadas, e possui vista para o dorso do Pico da Tijuca, parte da Baía de Guanabara, Zona Norte e Serra do Mar, contribuindo para discussões e divulgação destes elementos sob a ótica da geologia, geografia, história entre outras ciências. A relação com o porte da vegetação e raízes na trilha com o relevo também contribuem para a realização desta atividade. 


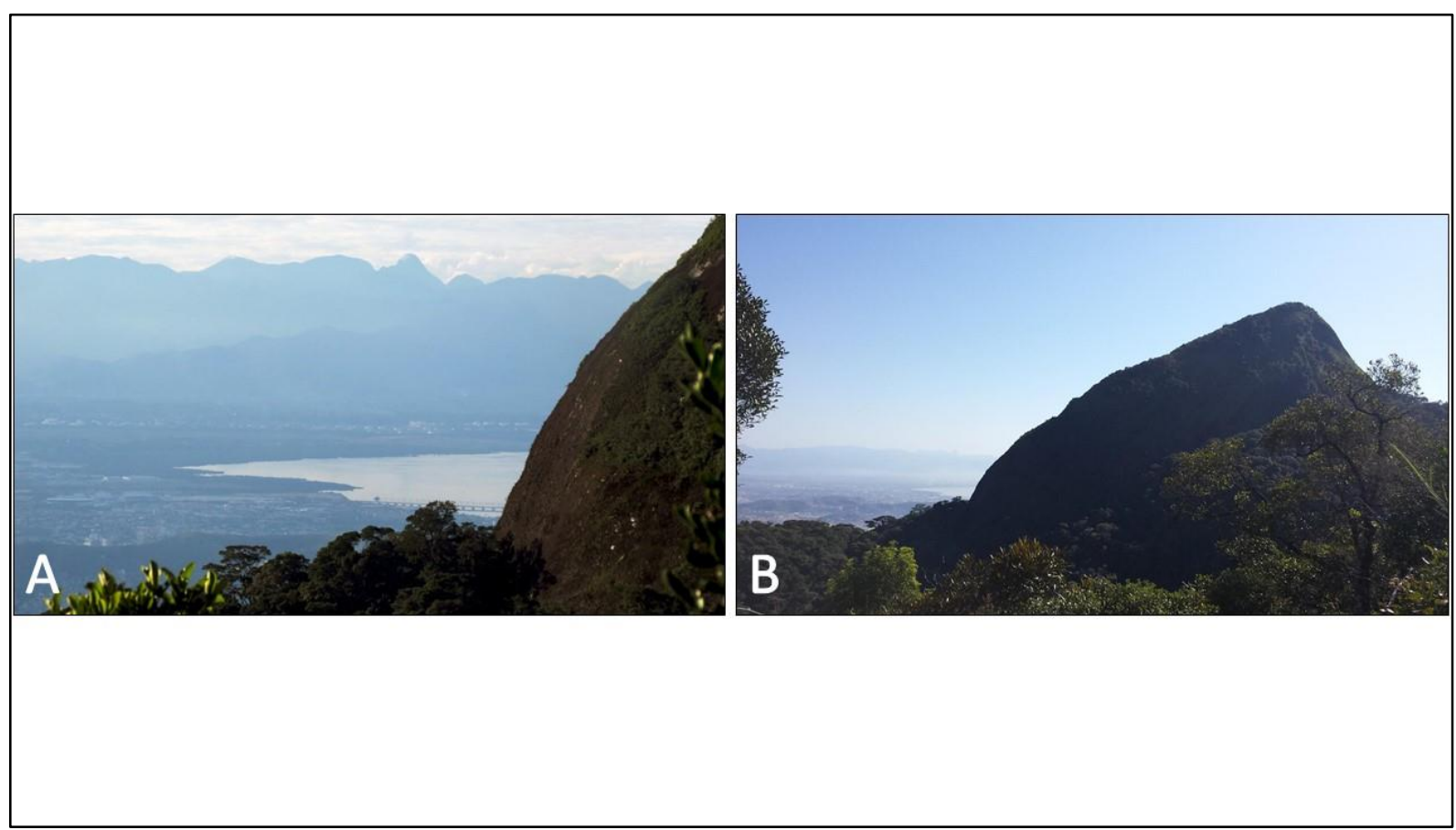

Figura 51: Morro do Archer. A- Vista para a Serra dos órgãos e Região Metropolitana do Rio de Janeiro. Fonte: Etrilhas. Disponível em: https://etrilhas.com.br/trilhas/morro-do-archer. Acessado em: 22/05/21; B- Vista para o Pico da Tijuca, com presença de vegetação densa. Fonte: Wikiloc. Disponível em: https://pt.wikiloc.com/trilhas-trekking/circuito-parna-tijuca-inclui-o-trecho-12-datranscarioca-28215820/photo-18023231. Acessado em: 22/05/21.

\section{Pico do Papagaio}

O Bico do Papagaio ocorre no extremo noroeste da bacia e é o segundo local mais alto do Parque, com 990 metros. Apresenta melhor acesso pelo Caminho do Bico do Papagaio, que se inicia no Largo do Bom Retiro, mas, também é possível ir pela Caminho da Serrilha do Papagaio, que apresenta maior nível de dificuldade e mais locais de observação da paisagem (figura 52).

O Pico é caracterizado por afloramento de Granito (Granito Favela) intrudido no complexo Rio Negro e a forma de relevo de crista elevada. Possui fraturamentos em todo o afloramento do Pico e vista panorâmica, onde se observa a Baixada de Jacarepaguá, Pedras da Gávea, Bonita e Agulhinha da Gávea, Barra da Tijuca, grande parte da Floresta da Tijuca e do Maciço, Serra do Mar e Baía de Guanabara.

A base do Pico possui escada de madeira para facilitar o acesso. Há uma passagem estreita, conhecida como fenda do inferno, na qual os visitantes precisam se agachar para passar. Para chegar ao seu topo, é necessário fazer escalaminhada sobre o afloramento. É um dos melhores sítios para se observar a compartimentação da bacia hidrográfica, assim como, para promover estudos e descrições para visitantes sobre a dinâmica de divisores de drenagem, resistência litológica, erosão 
diferencial, cabeceiras de drenagem, evolução geomorfológica e histórico de ocupação da Baixada de Jacarepaguá e história socioeconômica do Maciço da Tijuca.

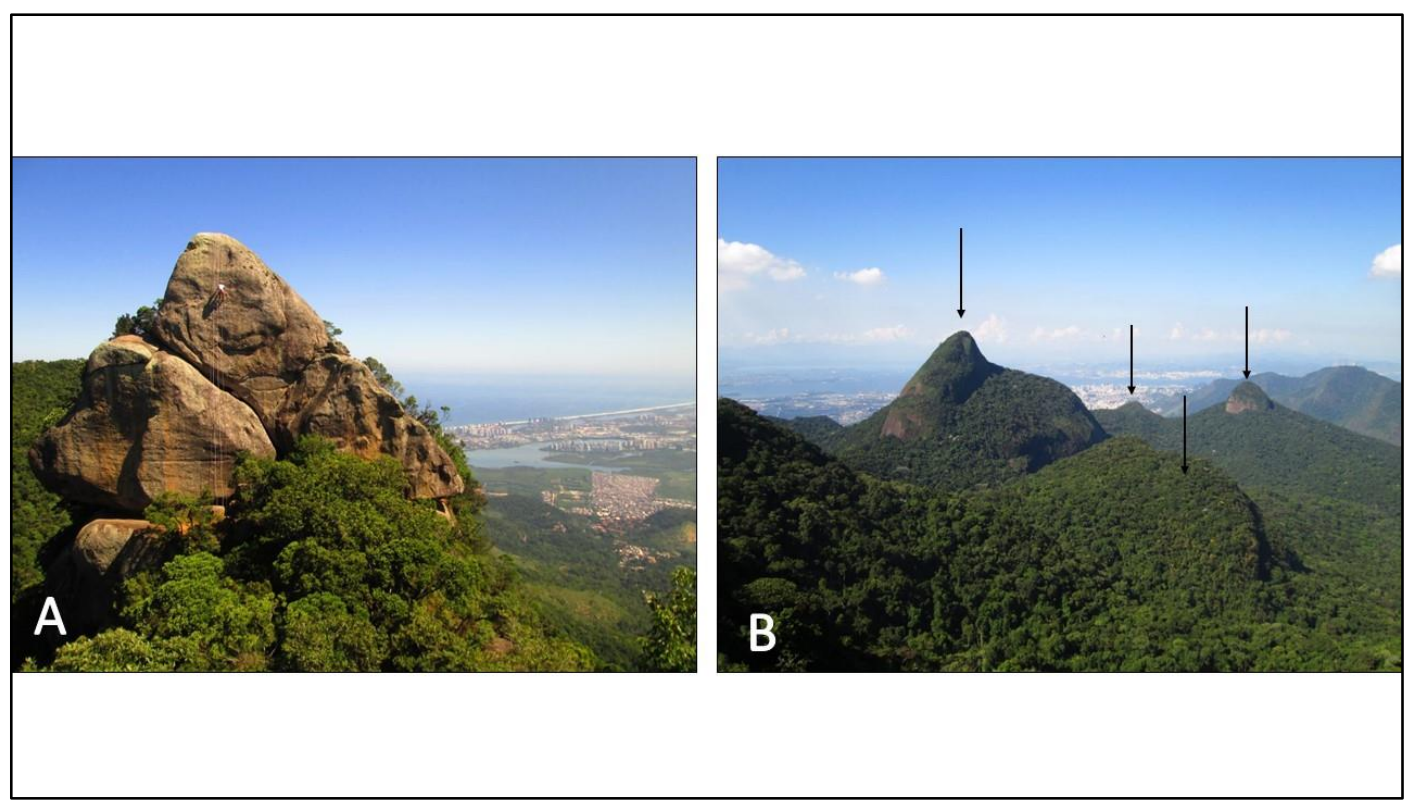

Figura 52: Pico do Papagaio. A- Vista do sítio de geodiversidade, Barra da Tijuca e Baixada de Jacarepaguá a partir da Pedra do Ururbu. Fonte: Saga Transcarioca. Disponível em: http://sagatranscarioca.com/bico-do-papagaio-via-serrilha/. Acessado em: 22/05/21; B- Vista para grande parte do alto curso da bacia do rio Tijuca, com setas indicando para o Morro do Archer, Pico da Tijuca, Morro do Anhanguera e Pedra do Conde. Fonte: Saga Transcarioca. Disponível em: http://sagatranscarioca.com/bico-do-papagaio-via-serrilha/. Acessado em: 22/05/21.

\section{4) Propostas de Ações Para a Promoção do Geoturismo no Parque Nacional da Tijuca}

Os resultados obtidos forneceram com clareza os caminhos a serem desbravados para a promoção do geoturismo. A estruturação da geodiversidade no Maciço da Tijuca e no alto curso da bacia hidrográfica do rio Tijuca apresenta riqueza de informações que auxiliam em divulgação científica, atividades esportivas e/ou recreativas, visitas escolares, além de ser um laboratório a céu aberto para ser realizados trabalhos de campo de diversas disciplinas associadas as Ciências da Terra, Biológicas e Sociais.

Os mapas de hipsometria e declividade fornecem informações básicas, porém úteis, para guiar nas visitações e associar as formas de relevo. As áreas com maiores elevações e inclinações se vinculam as rochas ortoderivadas e magmáticas, manifestando na paisagem maior imponência e resistência aos ataques intempéricos, a exemplo dos picos no setor alto da bacia do rio Tijuca e Pedra da Gávea. Os quartzitos, por sua vez, estão nos morros ocupando, inclusive, seus topos 
e também na colina próxima ao recanto dos pintores na Floresta da Tijuca, denominada pela gestão do Parque como Morro do Alto Mesquita. Já as demais litologias paraderivadas, ocupam a base dos morros e leito do rio Tijuca, a exemplo do biotita gnaisse, que entre o centro de visitantes e o limiar para a Cascatinha de Taunay, é possível observar trechos rochosos do canal fluvial (figura 53).

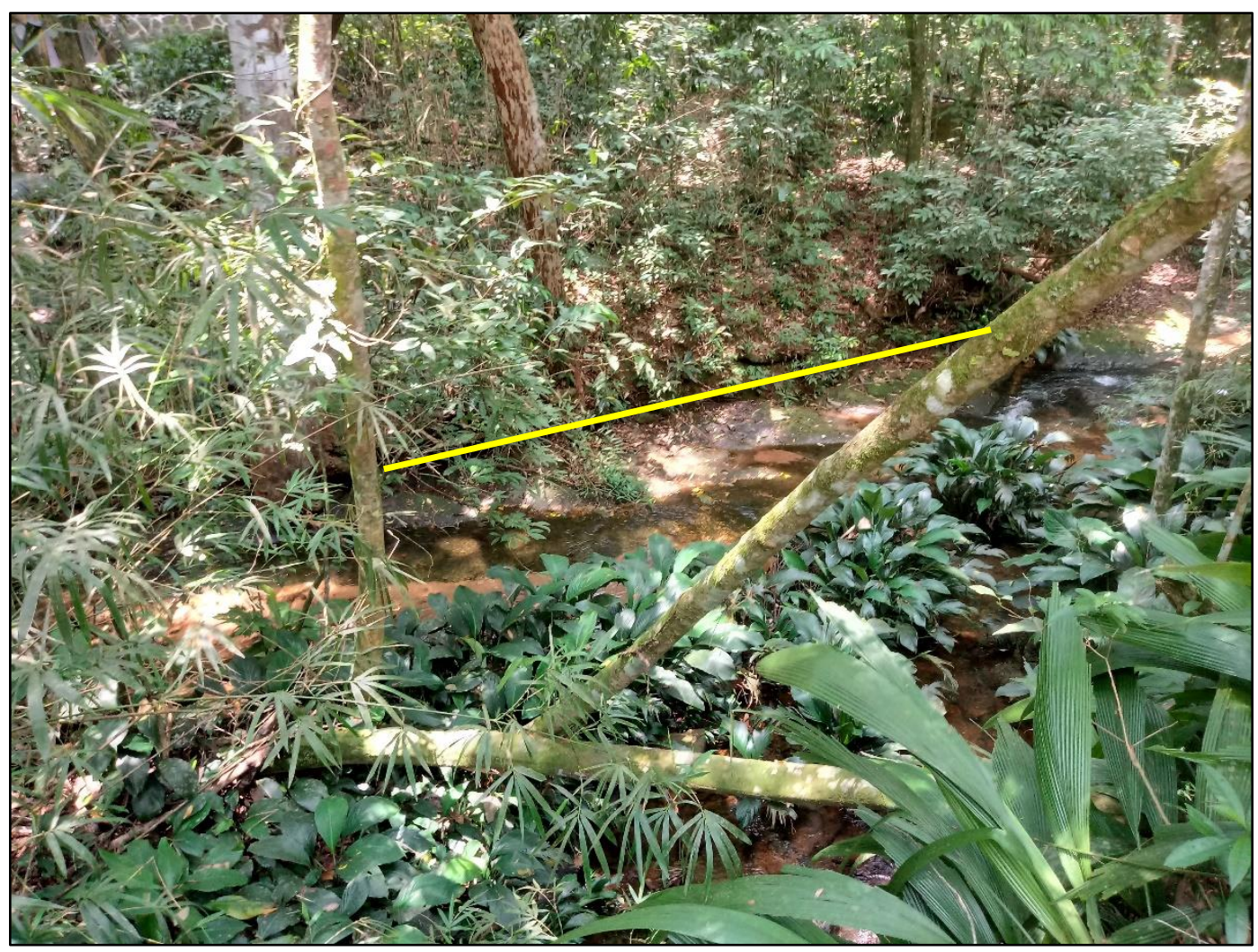

Figura 53: Rio Tijuca, próximo ao Centro de Visitantes do PNT. Linha amarela indica contato entre os depósitos aluvio-coluvionares, acima, e embasamento de biotita gnaisse abaixo.

Um fator que chama atenção é a presença de categorias menos acentuadas de declividades (plano, suave ondulado, ondulado e moderadamente ondulado) e classes de áreas planas e vales rasos no alto curso da Bacia do Rio Cachoeira, (com destaque para as Sub Bacias dos Rios Tijuca e Gávea Pequena), ressaltando a ocorrência de vales suspensos. Estes locais permitem formular algumas ponderações sobre a evolução geomorfológica do maciço e do SRCSB (ZALÁN e OLIVEIRA, 2005), pois são patamares preservados que indicam a existência de um vale suspenso. Vales suspensos estão relacionados a retenção de sedimentos e influência tectônica, com ocorrência de nível de base local (knickpoints) $e$ cachoeiras, como da cascatinha de Taunay, na Floresta da Tijuca. Estas feições, são garantidas pela resistência litológica das rochas que dificultam o entalhe fluvial mantendo seus níveis topográficos mais altos. 
O mapa geomorfológico apresentou o detalhamento das vertentes, fato este muito interessante, pois vai além da perspectiva tradicional, na qual se classifica as vertentes como convexa, côncava e retilínea. As classes encontradas apresentam variação em sua nomenclatura, o que demonstra haver várias possibilidades para as análises do relevo.

No trabalho de campo, se verificou a necessidade da construção de mapeamento baseado no $4^{\circ}$ táxon, conforme proposto por Ross (1992) e Dantas (2013), apesar do objetivo de mapear no $5^{\circ}$ táxon ser atingido. Este fato salienta a importância da realização de atividades práticas em geomorfologia, pois em imagens orbitais nem sempre se consegue obter um bom esclarecimento da compartimentação do relevo.

Visando o geoturismo, o mapa construído com base no índice de posição topográfica se mostra adequado, visto que as denominações das classes não são de difícil entendimento e expressa a diversidade do modelado terrestre. Palavras como vale, plano e topos, facilitam a compreensão dos turistas.

O mapa de índice de geodiversidade baseado nos principais aspectos (geologia, geomorfologia e solos) apresentou para a bacia do rio tijuca baixa e média geodiversidade. O setor baixo apresentou índice baixo e os setores médio e alto apresentaram baixa e média geodiversidade. Já o mapa baseado em geologia, geomorfologia, solos e hidrografia (canais fluviais) se caracterizou por apresentar em sua maior parte média e alta geodiversidade, com uma pequena parte de índice baixo. A inclusão da hidrografia fez enorme diferença, pois é um elemento que possui alta ocorrência na área foco de estudo e se destaca na paisagem. Nesta classificação, o setor baixo apresentou índice médio, o setor médio se caracteriza com média e alta geodiversidade e por fim, o setor alto com baixa, média e alta geodiversidade. O refinamento das variáveis utilizadas neste mapeamento, poderá auxiliar e dar maiores detalhes sobre a variedade abiótica, porém pode ser incluído nas atividades de turismo, fazendo associação com a localização dos sítios.

O mapa litológico expõe o nome das rochas encontradas, se tornando fundamental para atividades geoturísticas, devido a nomenclatura mais básica. Perfis em 3D são produtos necessários, que podem ser muito úteis para a exposição das informações da geodiversidade da bacia, tanto para o relevo como para geologia (como pode ser ilustrada na figura 54). A relação entre estes é intrínseca. 
Na trilha para a Pedra do Conde, há um trecho conhecido como Areião, devido a presença de sedimentos oriundos da erosão dos quartzitos, com areias grossa, muito grossa, grânulos e blocos. Entretanto, na Estrada do Excelsior, após a ponte das Almas e entrada da Trilha da Lagartixa (trilha para prática de Montain Bike), há muitas areias quartzíticas, em maior quantidade que no Morro do Areião. Esta constatação se torna uma informação útil para a identificação de rochas de um determinado local e ser adicionados a cartilhas de geoturismo. É notável a relação entre esta rocha com a vegetação, que se apresenta seca e menor, apesar de haver também, diversas marcas antrópicas através do reflorestamento da Floresta da Tijuca, iniciado na segunda metade do século XIX.

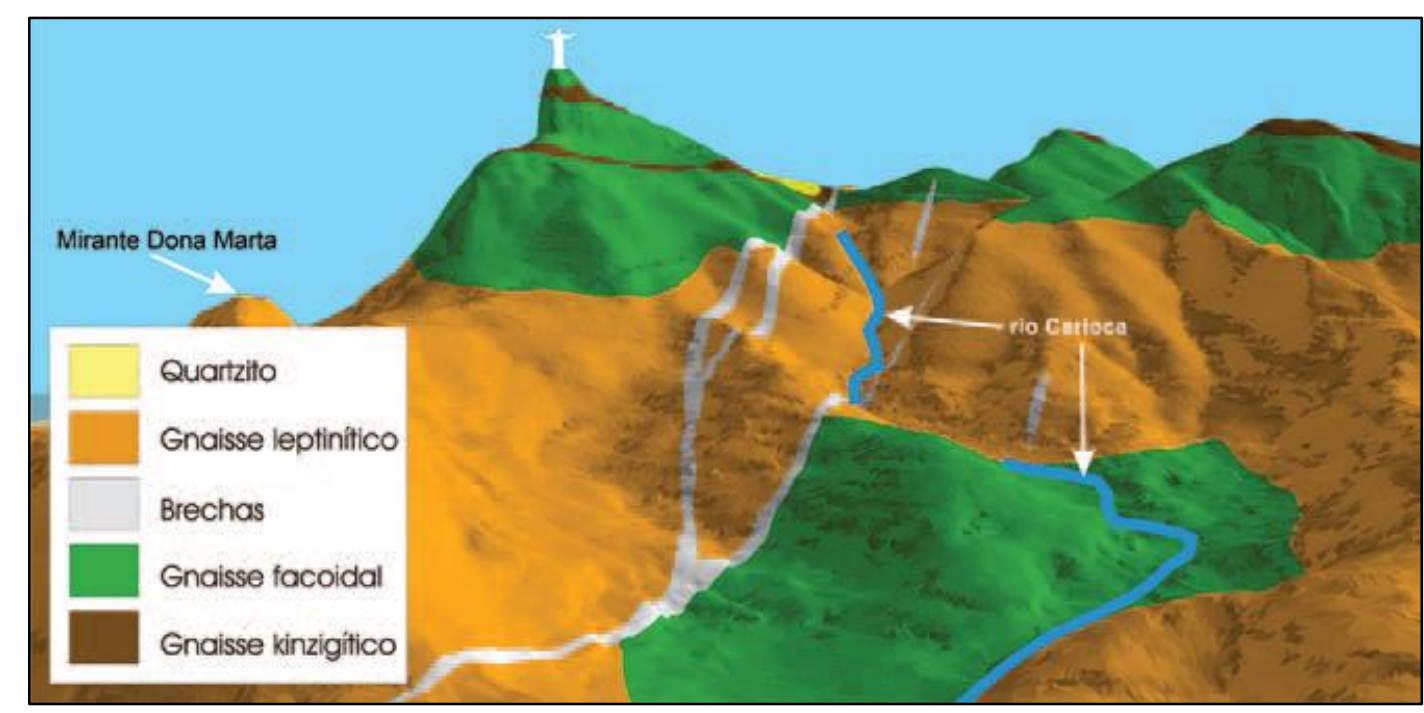

Figura 54: Exemplo de placa indicativa sobre a Geologia do Corcovado e arredores. Fonte: Painel interpretativo fixado no Corcovado pelo Serviço Geológico do Estado do RJ. Projeto Caminhos Geológicos - DRM, 2007. Extraído de Beliani \& Scheiner (2012).

O Gnaisse Facoidal na Pedra do Conde, possui alto grau de dureza. Na parte da trilha de acesso ao topo da Pedra do Conde, há afloramento com declividade acentuada, onde é possível observar melhor o gnaisse. Após a bifurcação em direção ao Morro do Anhaguera, ocorre trechos com nascente do rio do Conde e o sopé do Morro da Pedra do Conde, com afloramento que se destaca na paisagem e com matacões rolados. Após esses pontos, há um afunilamento do divisor das bacias dos rios Tijuca e Maracanã, com a presença de quartzitos, apresentando vertente bastante declivosa para a última bacia citada. São excelentes pontos para a fixação de placas explicativas sobre aspectos petrológicos, geomorfológicos, hidrológicos e morfométricos. 
A presença de matacões de ortognaisses e granito no setor alto, trazem o alerta sobre o risco de movimentos de massa classificados movimentos de blocos, sendo divididos em: queda, tombamento, rolamento e desplacamento. Tais processos fazem parte da evolução da superfície terrestre e pode afetar a sociedade, inclusive em áreas de conservação, haja visto as altas taxas pluviométricas e altas declividades no Maciço da Tijuca. Também é necessário, a produção de materiais de informações sobre as cicatrizes de deslizamentos e mapa sobre os pontos suscetíveis a estes eventos extremos. A divulgação científica contendo explicações sobre isto, é muito importante e contribui nas escolhas de áreas de visitação, sobretudo em dias de chuva.

Os sítios necessitam de melhores sinalizações, placas com descrições sobre aspectos históricos, bióticos e abióticos. Há diversos pontos levantados que possuem alto valor para o turismo e para as pesquisas científicas. Na área em que o presente trabalho focou, o alto curso da bacia do rio Tijuca, as poucas placas explicativas existentes mencionam os fatores bióticos e fluxo hídricos nas árvores e serrapilheira, nas quais se encontram em sua maioria em estado de conservação ruim (figura 55). Para que o Geoturismo se torna uma prática efetiva, que complementa o ecoturismo e auxilia no planejamento ambiental, é necessário a realização das demais etapas de geoconservação, propostas por Brilha (2005): quantificação, classificação, conservação, valorização, divulgação e monitorização. Locais que não considerados sítios também necessitam de instalações com informações locais. 


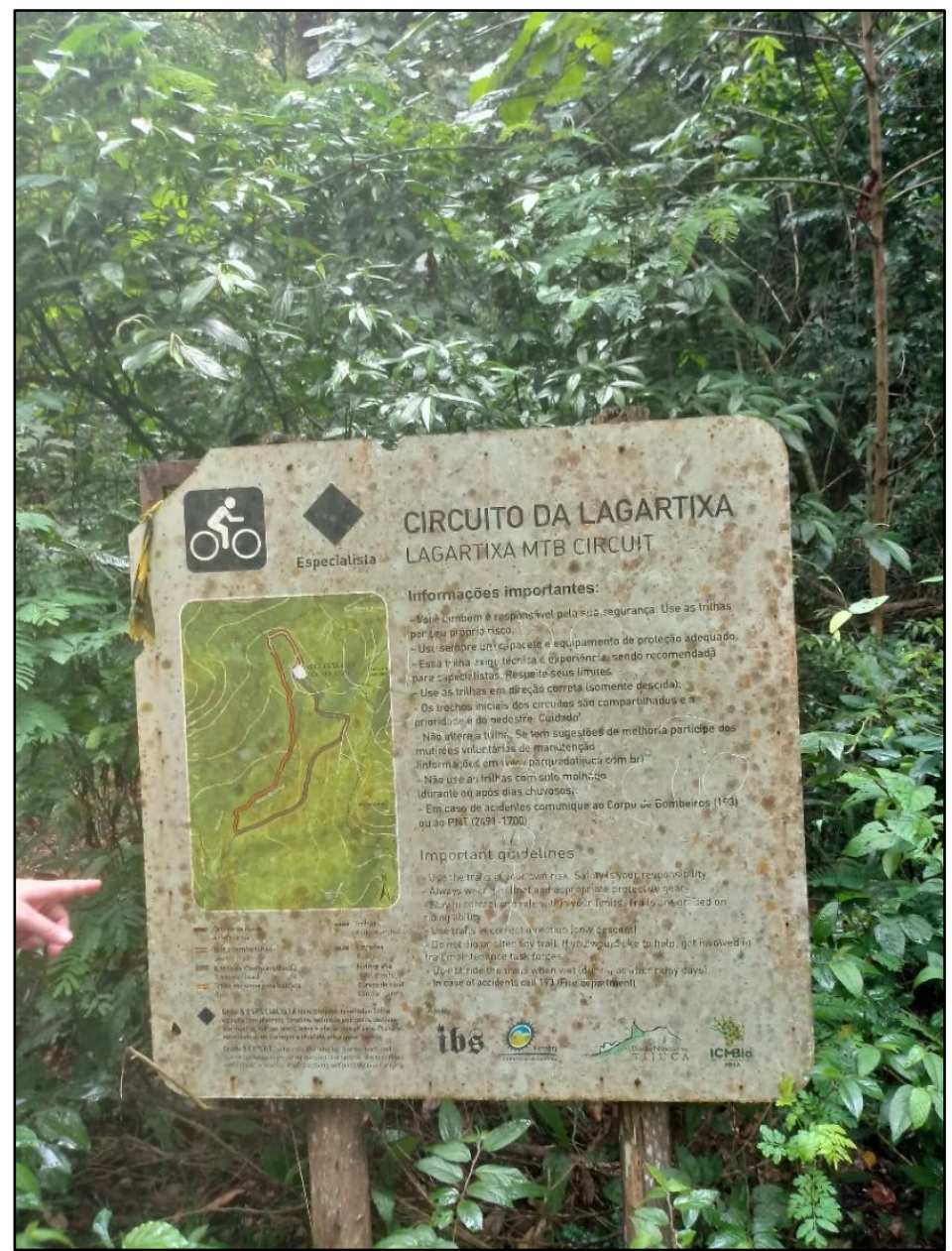

Figura 55: Placa na entrada do Circuito da Largatixa de Montain Bike, na sub-bacia hidrográfica do rio Caveira. Destaque para a falta de manutenção do material, que está enferrujado.

A geodiversidade associada a perspectiva dos serviços ecossistêmicos pode ser tornar uma via relevante para a conservação ambiental, pois demonstra de maneira eficiente o quanto os componentes abióticos auxiliam a sociedade como um todo, como observado por Gray (2013). A concepção de ecossistema, teoricamente envolve o entrelaçamento de elementos vivos e não vivos, porém os primeiros possuem maior visibilidade e valorização. Segundo Silva et al. (2018, pág. 707):

"O termo serviços ecossistêmicos, apesar de ter sido definido inicialmente para os estudos da biodiversidade, possui, em sua essência, possibilidade de aplicação nos estudos abióticos, necessitando, porém, algumas adaptações para que o modelo seja usado numa avaliação mais ampla, de forma a valorar a participação da geodiversidade na diversificação do meio ambiente, como base essencial para a vida".

As placas, folders, totten, cartilhas, sites e aplicativos são ferramentas primordiais, porque são produtos visuais, que facilitam a compreensão do público leigo. Após o levantamento em gabinete e em campo no alto curso da bacia de 
drenagem do rio Tijuca, podemos constatar que os atributos de geodiversidade estão presentes na maioria dos destinos. Em análise geral, o relevo é o foco principal das visitações, haja visto a existência dos mirantes, trilhas que levam aos picos e cachoeiras.

Todas estas áreas mencionadas fornecem a compreensão da evolução dos tipos de relevo, da formação do rift da Guanabara e do Oceano Atlântico e também o entendimento sobre a história e dinâmica das ocupações no Rio de Janeiro. Como perspectiva futura, a realização do refinamento dos mapas supracitados, seria um grande avanço para aprofundar as questões aqui apresentadas. 


\section{6) Considerações Finais}

O presente trabalho objetivou estabelecer um panorama e obter novas informações sobre o relevo e a geodiversidade do Parque Nacional da Tijuca. As técnicas de geoprocessamento foram fundamentais para o desenvolvimento da pesquisa. Os conceitos abordados forneceram amplo embasamento para o entendimento dos resultados encontrados.

Os mapas produzidos podem contribuir no manejo do parque e estar em cartilhas e ou placas educativas para os visitantes, além de possibilitar ser um informativo para situações extremas, como a ocorrência de deslizamentos e incêndios. As informações sobre as trilhas necessitam estar acopladas ao mapa geológico, geomorfológico e hipsométrico, nas quais permitirão ao turista analisar seu local de preferência a ser visitado e aos gestores do parque nas tomadas de decisão. Os índices de geodiversidade apresentados dão uma síntese da organização espacial dos elementos abióticos, porém devem ser vistos de forma integrada ao mapa de sítios de geodiversidade, pois a ocorrência de locais com classes alta e muito alta não está atrelada a um cenário de muitos geossítios e sítios de geodiversidade, pois o índice mostra a mensuração de maior ou menor ocorrência da variedade de aspectos abióticos e não de locais com relevância de geodiversidade.

O mapeamento do relevo expôs os níveis de altitude, inclinação e formas de relevo. Cada vez mais o uso de dados morfométricos estão sendo utilizados no âmbito da ciência geomorfológica e a utilização do índice de posição topográfica possibilitou o detalhamento das classes de relevo, que se relacionam intimamente com o quinto táxon exposto por Ross (1992).

Os dados de geologia, geomorfologia e pedologia auxiliaram de maneira concisa nos resultados e no entendimento da configuração ambiental da área de estudo, mesmo com as limitações das escalas. A inclusão da hidrografia no mapeamento mudou a perspectiva sobre os níveis de concentração da geodiversidade, porém a geologia, relevo e solos são os elementos essenciais nestas análises.

O mapa litológico trouxe refinamento de informações sobre a litologia do alto curso da bacia do rio Tijuca. Há limitações, devido à dificuldade de encontrar os 
contatos exatos, devido aos processos erosivos. No entanto, trata-se de material inédito e que poderá auxiliar no geoturismo.

Portanto, as avaliações até aqui apresentadas, permitem elaborar estratégias conservacionistas e popularização da ciência. Alguns locais de visita podem ser considerados previamente como geossítios ou sítios de geodiversidade, pois possuem forte apelo popular e/ou científico, como os picos e mirantes, porém é necessário realizar mais trabalhos de campo para verificar a possível existência de mais sítios de geodiversidade.

O Parque Nacional da Tijuca é uma unidade de proteção integral, aonde não é permitido ter moradias, somente instalações vinculadas ao órgão de proteção ambiental. A população ao redor do parque é grande e necessita estar inserida no cotidiano do parque, através da colaboração, a exemplo de fóruns, mapeamento participativo, questionários entre outros.

A conscientização sobre a importância das formas de relevo, geodiversidade e da conservação ambiental pode ser um viés capaz de impulsionar o desenvolvimento territorial. Estes temas possuem uma forte vinculação com o conceito de paisagem, mas a questão territorial também se torna relevante, pois a exemplo do Maciço da Tijuca, as territorialidades são diversas, o que correlaciona com Rua (2007), no qual afirma que os múltiplos desenvolvimentos e múltiplas sustentabilidades estão alicerçadas na identidade territorial, tendo o território marcado por relações de poder, explícitas ou simbólicas, exercidas por atores diversos, numa arena de luta em que confrontam suas visões de mundo. 


\section{7) Referências Bibliográficas}

ALMEIDA, F.F.M. The system of continental rifts bordering the Santos Basin, Brazil. An. Acad. Bras. Ciências, Rio de Janeiro, 1976, 48:15-26.

ALMEIDA, F.F.M.; AMARAL, G.; CORDANI, U.G.; KAWASHITA, K. 1973. The Precambrian evolution of the South American Cratonic Margin South of Amazonas River. In: The Ocean Basin and Margins (Nairn \& Stille, Eds.), 1:411446, Plenum, New York.

ALMEIDA, F. F. M. de; CARNEIRO, C. D. R. Origem e evolução da Serra do Mar. Revista Brasileira de Geociências, São Paulo, v. 28, n. 2, p. 135-150, jun. 1998.

ALVARENGA, L. A. Precipitação no sudeste brasileiro e sua relação com a Zona de Convergência do Atlântico Sul. Revista Agrogeoambiental, v.4, n.2, agosto 2012.

ARONA, T. N. Lugares de Interesse Geológico e proposta de georroteiro na Trilha Transcarioca. Trabalho de conclusão de curso. Instituto de Geociências, Universidade Federal do Rio de Janeiro. Rio de Janeiro, 2017.

ASMUS, H. E.; FERRARI, A. L. Hipótese sobre a causa do tectonismo cenozóico da região Sudeste do Brasil. Rio de Janeiro: PETROBRAS, 1978. p. 75-88. (Série Projeto REMAC, 4).

BELIANI, E.; SCHEINER, T. A Contribuição da Museologia para a Difusão do Patrimônio Geológico do Parque Nacional da Tijuca. Anuário do Instituto de Geociências/UFRJ, v. 35, n. 1, p.68-79 (2012).

BORSATO, V. A.; MENDONÇA, F. A. A participação da massa tropical atlântica no estado do tempo no Centro Sul do Brasil. GeoNorte, v. 4, p. 293 304, 2012.

BETARD, F.; PEULVAST, J. P. Geodiversity Hotspots: Concept, Method and Cartographic Application for Geoconservation Purposes at a Regional Scale. Environmental Management, P. 822-834, 2019.

BOTELHO, R. G. M.; PELECH, ANDRÉ S. Do Mapeamento Geomorfológico do IBGE a um Sistema Brasileiro de Classificação do Relevo. Revista Brasileira de Geografia, v. 64, p. 183-201, 2019.

BRILHA, J. Patrimônio Geológico e Geoconservação: a conservação da natureza em sua vertente Geológica. Braga: Palimage, 2005. 190 p.

BRILHA, José. Inventory and Quantitative Assessment of Geosites and Geodiversity Sites: A Review. Geoheritage, v. 8, p. 119-134, 2016.

CHEN, A.; NG, Y.; ZHANG, E.; TIAN, M. Dictionary of Geotourism. Pequim: Springer, 2020.

CPRM. Mapa geodiversidade do Brasil. Escala 1:2.500.000. Legenda expandida. Brasília: CPRM/Serviço Geológico do Brasil, 2006. 68 p.

CPRM. Carta de Geodiversidade da Folha Rio de Janeiro. Escala 1:1.000.000. CPRM, 2006.

CPRM - Serviço Geológico do Brasil. Geossit: cadastro de sítios geológicos. Disponível em: http://www.cprm.gov.br/geossit. Acesso em: 30 Jul 2020.

COELHO NETTO, Ana Luiza. A Interface florestal-urbana e os desastres naturais relacionados à água no Maciço da Tijuca: desafios ao planejamento urbano numa perspectiva sócio-ambiental. Revista do Departamento de Geografia (USP), São Paulo, v. 16, n.3, p. 46-60, 2005. 
COELHO NETTO, A. L.; AVELAR, A. S. ; FERNANDES, M. S. ; LACERDA, W. A. Landslide susceptibility in a mountainous geoecosystem, Tijuca Massif, Rio de Janeiro: the role of morphometric subsivision of the terrain. Geomorphology (Amstrerdam), Estados Unidos, v. 87, p. 120-131, 2007.

DANTAS, M. E. Geomorfologia do Estado do Rio de Janeiro. Disponível em: < http://www.cprm.gov.br/publique/Gestao-Territorial/Geologia\%2C-Meio-

Ambiente-e-Saude/Projeto-Rio-de-Janeiro-3498.html> . Acesso em 20/03/2019.

DANTAS, M. E. Análise de padrões de relevo: um instrumento aplicado ao mapeamento da Geodiversidade. In: íris Celeste Nascimento Bandeira. (Org.). Geodiversidade do Estado do Maranhão. 1ed.Teresina: CPRM - Serviço Geológico do Brasil, 2013, v. 1, p. 133-140.

DANTAS, M. E. Carta de padrões de relevo do Município do Rio de Janeiro. Disponível em: < http://www.cprm.gov.br/publique/Gestao-Territorial/GestaoTerritorial/Cartas-de-Padroes-de-Relevo-Municipais-5423.html>. Acesso em 22/03/2020.

DEMEK, J. Manual of detailed geomorphological mapping. Praga: Academy of Sciences, 1972.

DEPARTAMENTO DE PRODUÇÃO MINERAL. Geodiversidade do Brail: sobre a construção das geociências. Rio de Janeiro: DNPM, 2005.

DIAS, M. A. ; COELHO NETTO, A. L. A Influência da Topografia na Distribuição de Manchas de Gramínea em um Fragmento de Floresta Atlântica Urbana Montanhosa, Maciço da Tijuca, RJ. Revista Brasileira de Geomorfologia, v. 12, p. 3-14, 2011.

DOWLING, R. \& NEWSOME, D. 2006. Geotourism: sustainability, impacts and management. elsevier, 352p., 2006.

Eirado Silva, L. G.; NAVA, D. B.; HEILBRON, M. ; VALERIANO, C. Geologia de detalhe da Serra da Carioca, cidade do Rio de Janeiro, RJ. In: II Simposio de Geologia do Sudeste, 1991, São Paulo. Atas do II Simposio de Geologia do Sudeste, 1992. p. 161-169.

FARIAS, L. F.; MACHADO, D. M. C. ; TEIXEIRA, I. S. N. As múltiplas visões patrimoniais e as valorações da geodiversidade da área do Parque Lage (Parque Nacional Da Tijuca), Município Do Rio De Janeiro (RJ). In: I Simpósio Brasileiro De Patrimônio Geológico/II Congresso Latino-Americano e do Caribe Sobre iniciativas em Geoturismo, 2011, Rio De Janeiro. Atas Do I Simpósio Brasileiro de Patrimônio Geológico/II Congresso Latino-Americano e do Caribe sobre iniciativas em geoturismo. Rio De Janeiro: UFRJ, 2011. P. 18-18.

FRANCISCO, C. N. Mapeamento de Áreas de Risco de Deslizamentos e Desmoronamentos do Parque Nacional da Tijuca (RJ) e Entorno através de Sistemas Geográficos de Informação. In: SEMANA ESTADUAL DE GEOPROCESSAMENTO, 1996, Rio de Janeiro. Anais. Rio de Janeiro: Fórum Estadual de Geoprocesamento, 1996. p. 197-230.

FERNANDES, M. C.; MENEZES, P. M. L. Avaliação de métodos de geração de MDE para a obtenção de observações em superfície real: um estudo de caso no maciço da Tijuca - RJ. REVISTA BRASILEIRA DE CARTOGRAFIA (IMPRESSO), Presidente Prudente - SP, v. 57, n.2, p. 154-161, 2005.

FERNANDES, M. C.; AVELAR, A. S. ; COELHO NETTO, A.L. Domínios Geohidroecológicos do Maciço da Tijuca/RJ. Anuário do Instituto de Geociências (UFRJ. Impresso), Rio de Janeiro - UFRJ, v. 29, n.2, p. 122-148, 2006. FERNANDES, M. C.; AVELAR, A. S. ; Avelar, AS ; MENEZES, P. M. L. ; COELHO NETTO, A. L. . Comparação do uso de superfície real e 
planimétrica para análise do índice de eficiência de drenagem: um estudo de caso no Maciço da Tijuca - RJ. Revista Brasileira de Geomorfologia, v. 13, p. 2937, 2012.

FERRARI, A. L. Evolução tectônica do Grabén da Guanabara. Tese (Doutorado). Insttuto de Geociências, Universidade de São Paulo. São Paulo, 2001. FERRARI, A. L.; MELO, C. L. Neotectônica. Curso. IX Simpósio Nacional de Estudos Tectônicos. 2003. Armação de Búzios, RJ.

FIGUERÓ, A. S.; COELHO NETTO, A. L. Análise da variabilidade térmica em zonas de bordas florestais com interface urbana no Maciço da Tijuca, Rio de Janeiro - RJ. Ciência e Natura, v. 29, p. 173-186, 2007.

FIGUEIRÓ, A. S; COELHO NETTO, A. L. Impacto Ambiental ao Longo de Trilhas em Áreas de Floresta Tropical de Encosta: Maciço da Tijuca, Rio de Janeiro, RJ. Mercator - Revista de Geografia da UFC, v. 16, p. 187-200, 2009.

FLORENZANO, Tereza Gallotti. Geomorfologia: conceitos e tecnologias atuais. São Paulo: Oficina de Textos, 2008.

FORTE, J. P. Avaliação quantitativa da geodiversidade: desenvolvimento de instrumentos metodológicos com aplicação ao ordenamento do território. Tese (Doutorado). Escola de Ciências, Universidade do Minho. Braga, 2014.

GAGLIANONE, P. C. Geologia e tectônica do intervalo serra do Engenho Novo - Sumaré, no Estado da Guanabara. Dissertação (mestrado). Instituto de Geociências, Universidade Federal do Rio de Janeiro. Rio de Janeiro, 1971.

GARCIA-CORTÉS, A.; URQUÍ, L.C. Documento Metodológico para la elaboracion del inventario espanñol de lugares de interés geológico (IELIG). Madrid: Instituto Geológico y Minero de España, 2009.

GRAY, M. Geodiversity: valuing and conserving abiotic nature. New York: John Wiley \& Sons, 2004. 434 p.

GRAY, M. Geodiversity: valuing and conserving abiotic nature. 2nd edition. Chichester, John Wiley \& Sons, 495 p. 2013.

HAESBAERT, R. Viver no limite: território e multi/transterritorialidade em tempos de in-segurança e contenção. 1. ed. Rio de Janeiro: Bertrand Brasil, 2014. v. $1.320 \mathrm{p}$.

HEILBRON， M. ; PIRES，F. R. M. ; VALERIANO, C. M.; BESSA, M. P. Litoestratigrafia, Evolução Tectono-Metamórfica e Magmatismo no Precambriano do Setor Sudeste do Município do Rio de Janeiro. In: III Simposio de Geologia do Sudeste, 1993. Atas do III Simposio de Geologia do Sudeste. Rio de Janeiro. p. 174-179.

HEILBRON, M. C. P. L.; PEDROSA-SOARES, AC; CAMPOS NETO, M; SILVA, LC; TROUW, R. A. J.; JANASI, V. C. A Província Mantiqueira. In: Mantesso-Neto, V; Bartorelli A, Carneiro CDR, Brito Neves, BB, 2004. (Eds.), O Desvendar de um Continente: a Moderna Geologia da América do Sul e o Legado da Obra de Fernando Flávio Marques de Almeida, XIII.

HJORT, J. LUOTO, M. Geodiversity of high-latitude landscapes in northern Finland. Geomorphology. v. 115, p. 109-116, 2010.

HOSE, T. European 'geotourism' - geological interpretation and geoconservation promotion for tourists. In: Geological Heritage: its conservation and management. D. Barettino, W.A.P. Wimbledon and E. Gallego (Eds.) pp.127146 Madrid (Spain), 2000.

INSTITUTO BRASILEIRO DE GEOGRAFIA E ESTATÍSTICA. Mapa de Unidades de Relevo do Brasil. Escala 1:5.000.000. $2^{\mathrm{a}}$ edição. Rio de Janeiro: IBGE, 2006. 
KLIMASZEWSKI, M. Thirty years of detailed geomorphological mapping. Geographia Polonica, 58, p. 11-18, 1990.

KOZLOWSKI, S. The concept and scope of geodiversity. Przegld Geologiczny, v. 52, n. 8/2, p. 833-837, 2004.

LAMEGO, A. R. O Homem e a Guanabara. Rio de Janeiro, IBGE, 1964.

LEPSCH, I. F.; BELLINAZZI JR., R.; BERTOLINI, D.; ESPÍNDOLA, C. R. Manual para levantamento utilitário do meio físico e classificação de terras no sistema de capacidade de uso. $4^{\text {a }}$ aproximação. Campinas: SBCS, 1991, 175p.

LOBATO, M. C.; Proveniência Sedimentar do Grupo São Fidélis, Terreno Oriental da Faixa Ribeira, com base em dados U/Pb. Dissertação (Mestrado). Faculdade de Geologia, Universidade do Estado do Rio de Janeiro, Rio de Janeiro, 2013.

LUMBRERAS, J. F.; GOMES, J. B. V. Mapeamento pedológico e interpretações úteis ao planejamento ambiental do município do Rio de Janeiro. Rio de Janeiro: Embrapa Solos, 2004. 331 p.

MAIA, R. O. C. A Floresta da Tijuca. Rio de Janeiro: Bloch, 1967.

MALTA, R. R.; COSTA, N. M. C. da . Gestão do Uso Público em Unidades de Conservação: A visitação no Parque Nacional da Tijuca-RJ. Revista Brasileira de Ecoturismo, v. 2, p. 273-294, 2009.

MANSUR, K. L. Diretrizes para Geoconservação do Patrimônio Geológico do Estado do Rio de Janeiro: o Caso do Domínio Tectônico Cabo Frio. Rio de Janeiro, 214p. Tese (Doutorado em Geologia) - Instituto de Geociências, Universidade Federal do Rio de Janeiro, 2010.

MAZUR, F. P. R. Mapeamento da susceptibilidade a movimentos de massa através de assinaturas ambientais no Maciço da Tijuca, Rio de Janeiro. Dissertação (Mestrado). Departamento de Engenharia Civil e de Meio Ambiente. Pontifícia Universidade Católica do Rio de Janeiro, Rio de Janeiro, 2013.

MOTOKI, A.; SICHEL, S. E.; SILVA, S.; MOTOKI, K. F.; RIBEIRO, A. $K$. Drainage erosion and concave landform of Tijuca Gneissic Massif, State Of Rio De Janeiro, Brazil, with the help of summit level and base level technique based on aster gdem. Geociências (São Paulo. Online), v. 34, p. 116, 2015.

NASCIMENTO, M. A. L.; RUCHKYS, Ú.A.; MANTESSO NETO, V. Geodiversidade, Geoconservação e Geoturismo: trinômio importante para a proteção do patrimônio geológico. São Paulo: Sociedade Brasileira de Geologia, 2008. 84p.

NUNES, R. S. A criação de um modelo de classificação semi-automática utilizando conhecimento geográfico: um estudo de caso na porção setentrional do Maciço da Tijuca - RJ. Dissertação (mestrado em Geografia). Departamento de Geografia e Meio Ambiente. Pontifícia Universidade Católica do Rio de Janeiro, Rio de Janeiro, 2013.

O ECO. UERJ lança guia sobre trilhas do Parque Nacional da Tijuca. Disponível em: https://www.oeco.org.br/noticias/27706-uerj-lanca-guia-sobretrilhas-do-parque-nacional-da-tijuca/. Acesso em: 25/04/21.

OLIVEIRA, P. C. A.; PEDROSA, A. S.; RODRIGUES, S. C. Uma abordagem inicial sobre os conceitos de Geodiversidade, Geoconservação e Patrimônio Geomorfológico. RA'E GA: o Espaço Geográfico em Análise, v. 29, p. 92-114, 2013.

PENHA, H. M.; Processos endogenéticos na formação do relevo. In: Guerra, A. T.; Cunha, S. B. Geomorfologia: uma atualização de bases e conceitos. Bertrand Brasil. $4^{\mathrm{a}}$ ed. 2001. 
PEREIRA, D.I.; PEREIRA, P. BRILHA, J. SANTOS, L. Geodiversity Assessment of Parana State (Brazil): An Innovative Approach. Environmental Management, v.52, p.541-522, 2013.

PINTO, V. Conheça tudo sobre o Caminho Dom Pedro Augusto - Floresta da Tijuca - RJ. Disponível em: https://www.vamostrilhar.com.br/aventuras/conhecatudo-sobre-o-caminho-dom-pedro-augusto-floresta-da-tijuca-rj/. Acesso em $12 / 05 / 21$.

PORTO JR., R.. Evolução do Conhecimento Geológico. In: Valeriano, C. de M.. (Org.). Valeriano, C. de M. 2011. Folha Baía de Guanabara, SF.23-Z-B-IV: texto e mapa. Programa Geologia do Brasil. PGB. Belo Horizonte: CPRM/UERJ. 1 CDROM.. 1ed.B. Horizonte: 2011, v. 1, p. 13-19.

PORTO JR., R.; DUARTE, B. P. Evolução do Conhecimento geológico na Cidade do Rio de Janeiro, Brasil. Memórias e Notícias (Nova Série) - Publicação do Departamento de Ciências da Terra e do Museu Mineralógico e Geológico da Universidade de Coimbra, v. 185, p. 45-53, 2012.

PRIEDOLS, E.; STORI, N.; SANCHEZ, PETRA S. Memória Ambiental Brasileira: Paisagens no Século XIX. In: $19^{\circ}$ Encontro da Associação Nacional de Pesquisadores em Artes Plásticas, 2010, Cachoeira - BA. Anais do ... Encontro Nacional da ANPAP (Cd-Rom), 2010. p. 263-275.

RICCOMINI, C. O Rift Continental do Sudeste do Brasil. Tese de Doutorado, Instituto de Geociências/USP. São Paulo, 256 p. 1989.

RICCOMINI, C.; SANT’ANNA, L.G.; FERRARI, A.L. Evolução geológica do Rift Continental do Sudeste do Brasil. In: Mantesso-Neto, V.; Bartorelli, A.; Carneiro, C.D.R; Brito Neves, B.B. (orgs.). Geologia do Continente SulAmericano: evolução da obra de Fernando Flávio Marques de Almeida. São Paulo, Beca, p.383-405. 2004.

ROSS J.L.S. Relevo Brasileiro: Uma Nova Proposta de Classificação. Revista do Departamento de Geografia, São Paulo, v. 4., p. 25-39, 1985.

ROSS. J.L.S. O registro cartográfico dos fatos geomorfológicos e a questão da taxonomia do relevo. Revista do Departamento de Geografia. São Paulo, n. 6, p.17-29, 1992.

ROSS, J.L.S., MOROZ, I.C. Mapa geomorfológico do Estado de São Paulo. Revista do Departamento de Geografia, São Paulo, v. 10, p. 41-58, 1996.

ROZA, A. G. Geoecoturismo aplicado à Floresta da Tijuca, Rio de Janeiro. Trabalho de conclusão de curso (graduação). Departamento de Geociências, Universidade Federal Rural do Rio de Janeiro/ UFRRJ. Rio de Janeiro, 2007.

RUA, João. Desenvolvimentos e sustentabilidades: uma perspectiva geográfica. In: OLIVEIRA, M.P. COELHO, M.C.N. CORRÊA, A, M. O Brasil, a América Latina e o Mundo: Espacialidades Contemporâneas. Rio de Janeiro: Lamparina. 2008.

RUCHKYS, Úrsula de Azevedo; OLIVEIRA, C. K.; JARDIM, H. L.; JORGE, L. M. S. Abordagem metodológica da Geodiversidade e temas correlatos em Geossistemas Ferruginosos. CADERNO DE GEOGRAFIA, v. 28, p. 1, 2018.

SATO, S. E.; LUPINACCI, C. M. Mapeamento geomorfológico de detalhe. In: SIMON, A.L.H.; LUPINACCI, C.M. (Org.). A cartografia geomorfológica como instrumento para o planejamento. 01ed.Pelotas: Editora da UFPEL, 2019, v. 01, p. 13-21.

SALES, G. P. S.; GUEDES-BRUNI, R. R. Floresta da Tijuca: paisagem de memória, história e biodiversidade. Revista Cátedra Digital, v. 6, p. 1-6, 2019. 
SANTOS, DANIEL S.; MANSUR, KÁTIA L.; GONÇALVES, JÉSSICA B.; ARRUDA, ELIAS R.; MANOSSO, FERNANDO C. Quantitative assessment of geodiversity and urban growth impacts in Armação dos Búzios, Rio de Janeiro, Brazil. APPLIED GEOGRAPHY, v. 85, p. 184-195, 2017.

SANTOS, D. S.; MANSUR, K. L..; DE ARRUDA JR, E. R.; DANTAS, M. E.; SHINZATO, E. Geodiversity Mapping and Relationship with Vegetation: A Regional-Scale Application in SE Brazil. Geoheritage, v. 11, p. 399-415, 2018.

SEMÊDO, P. A. 2017. Roteiro Geoturístico no Litoral do Rio de Janeiro: do Leme ao Pontal. Trabalho de Conclusão de Curso (Geologia) - Universidade Federal do Rio de Janeiro. Rio de Janeiro, 133p.

SERRANO, E.; RUIZ-FLAÑO, P. Geodiversidad: concepto, evaluación y aplicación terrotorial. El caso de Tiermes Caracena (Soria). Boletín de la Asociación de los Geógrafos Españoles, Madrid, v.45, p.79-98, 2007.

SILVA, M. L. N.; NASCIMENTO, M. A. L.; MANSUR, K. L. Nature Ecosystem Services and its Application on the Studies of Geodiversity: a Review. ANUÁRIO DO INSTITUTO DE GEOCIÊNCIAS (UFRJ. IMPRESSO), v. 41, p. 699-709, 2018.

SILVA, M.L.N.; NASCIMENTO, M. A. L.; MANSUR, K. L. Quantitative Assessments of Geodiversity in the Area of the Seridó Geopark Project, Northeast Brazil: Grid and Centroid Analysis. GEOHERITAGE, v. 11, p. 11771186, 2019.

SILVEIRA, C. T.; SILVEIRA, R. M. P. Classificação das formas de relevo na Serra do Marumbi (estado do Paraná - Brasil) com emprego do Índice de Posição Topográfica. In: XII SINAGEO, 2018, Crato. Anais do XII SINAGEO, 2018.

SILVEIRA, R. M. P. Proposta metodológica para mapeamento geomorfológico com uso da análise digital do relevo no estado do Paraná. Tese (Doutorado). Setor de Ciências da Terra, Universidade Federal do Paraná. Curitiba, 2019.

SLONGO, G. R. Desenvolvimento de um Sistema Triaxial Servo-Controlado e Avaliação do Comportamento Mecânico de um Solo Residual de Biotita Gnaisse. Dissertação (mestrado). Departamento de Engenharia Civil e de Meio Ambiente, Pontifícia Universidade Católica do Rio de Janeiro/ PUC Rio. Rio de Janeiro, 2008.

SHARPLES, C. Concepts and principles of geoconservacion. Disponível em: < https://www.researchgate.net/publication/266021113_Concepts_and_principles_o f_geoconservation> Acesso em: 05/07/20.

SILVA, T. P. Modelo Geológico-Geomorfológico da Evolução da Bacia Hidrográfica do Rio Paraíba do Sul. Tese de Doutorado. Programa de Pósgraduação em Geologia - Instituto de Geociências. UFRJ. 139p. 2012.

SOARES FILHO, A. Contribuições do geoprocessamento para a avaliação quantitativa da geodiversidade: Parque Estadual da Pedra Branca (RJ). Trabalho de conclusão de curso (Graduação). Instituto de Geociências, Universidade Federal do Rio de Janeiro. Rio de Janeiro, 2019.

SOBREIRA, F. G. Estudo de Encostas Ocupadas Desordenadamente na Cidade do Rio de Janeiro - A Favela do Vidigal. Dissertação (mestrado). Instituto de Geociências, Universidade Federal do Rio de Janeiro. Rio de Janeiro, 1989.

STANLEY, M. Geodiversity - Linking People, Landscapes and Their Culture. Disponível

em:<https://www.researchgate.net/publication/285890010_Geodiversity_linking _people_landscapes_and_their_culture> Acesso em 17/06/2020. 
SOUZA, A. R de.; MACHADO, Deusana Maria da Costa ; PEREIRA, J. W. ; VIEIRA, A. C. M. . A geosiversidade do Parque Nacional da Tijuca e a sua contribuíção para a identidade da Cidade do Rio de Janeiro. In: 44 Congresso Brasileiro de Geologia, 2008, Curitiba - Paraná. Anais - O Planeta Terra está em nossas mãos. Curitiba - Paraná: SBG, 2008.

TEIXEIRA, I. S. N.; MACHADO, Deusana Maria da Costa ; CASTRO, A. R. de S. F. de . Uma Ferramenta para Compreender a Apropriação do Patrimônio Geológico pela Sociedade: um Estudo Sobre o Morro do Corcovado/ Rio de Janeiro. Anuário do Instituto de Geociências (UFRJ. Impresso), v. 35_1, p. 123132, 2012.

TRICART, Jean. Cartographie Geomorphologique. Travaux de Ja RCP 77. Memoires et Documents, NS 12, p. 1-267, 1972.

VALERIANO, C. M. et al. Geologia e recursos minerais da folha Baía de Guanabara SF.23-Z-B-IV, estado do Rio de Janeiro escala 1:100.000. Cláudio de Morisson Valeriano [et al.]; organizador Luiz Carlos da Silva. - Belo Horizonte: CPRM, 2012. 156p.

VALERIANO, M. M. Dados topográficos. In: Teresa G. Florenzano. (Org.). Geomorfologia - conceitos e tecnologias atuais. 1ed.São Paulo: Oficina de textos, 2008, v., p. 72-104.

VASCONCELLOS, V. K. Aplcação do Modelo Elastoplástico de Lade Kim a um Perfil de Intemperismo de Leptinito. Tese (Doutorado em geologia). Instituto de Geociências, Universidade Federal do Rio de Janeiro, Rio de Janeiro, 2011.

VEIGA, A. T. C. A geodiversidade e o uso dos recursos minerais da Amazônia. Terra das Águas, Brasília: NEAz/ UnB, n. 1, p. 88-102, 1999.

VERSTAPEN, H.T.; ZUIDAM, R.A. Van. ITC System of geomorphological survey. Amsterdam: ITC, 3. Ed., 1975.

XAVIER DA SILVA, J.; CARVALHO FILHO, L. M. Índice de geodiversidade da restinga da Marambaia $(\mathrm{RJ})$ : um exemplo do geoprocessamento aplicado à geografia física. Revista de Geografia, Recife: DCG/UFPE, n. 1, p. 57-64, 2001.

ZALÁN, P. V. O Gráben da Guanabara: uma feição tectônica modelar mas pouco apreciada e entendida. In: CONGRESSO BRASILEIRO DE GEOLOGIA, 42., 2004, Araxá. Anais... Sociedade Brasileira de Geologia, 2004a. 1 CD-ROM. Trabalho S03:44.

ZALÁN, P.V.; OLIVEIRA, J.A.B. Origem e evolução estrutural do Sistema de Riftes Cenozóicos do Sudeste do Brasil. B. Geoci. Petrobras, 13(2):269-300. 2005.

WEISS, A. Topographic Position and Landforms Analysis. Poster presentation, ESRI User Conference, San Diego, CA, 2001. 